\title{
RESPONDING TO A DEMOCRATIC DEFICIT: LIMITING THE POWERS AND THE TERM OF THE CHIEF JUSTICE OF THE UNITED STATES
}

\author{
JUDITH RESNIK \& LANE DILG ${ }^{\dagger}$
}

This essay questions the wisdom and the constitutionality of the packet of powers now held by the Chief Justice of the United States. ${ }^{1}$ Many of the current attributes of the position are relatively recent additions, generated during the twentieth century through the interaction of a sequence of congressional decisions and the leadership of Chief Justices William Howard Taft, Earl Warren, Warren Burger, and William Rehnquist. These jurists responded to new demands as national law grew in importance in the American polity, and they introduced new ideas that gave the federal judiciary the capacity to function as a programmatic, agenda-setting agency.

${ }^{\dagger}$ All rights reserved, 2006. Judith Resnik, Arthur Liman Professor of Law, Yale Law School. Lane Dilg, Yale Law School, J.D. 2004.

${ }^{1}$ This article, first presented as a talk at the Symposium, The Chief Justice and the Institutional Judiciary, in November of 2005 at the University of Pennsylvania Law School, builds on several others, including Judith Resnik, Democratic Responses to the Breadth of Power of the Chief Justice, in REFORMING THE COURT: TERM LIMITS FOR SUPREME COURT Justices 181 (Roger C. Cramton \& Paul D. Carrington eds., 2006) [hereinafter Resnik, Democratic Responses]; Judith Resnik, So Long: Changing the Judicial Pension System Could Keep Judges from Staying on the Bench for Too Many Years, LEGAL AFF., July-Aug. 2005, at 20; Judith Resnik, Judicial Selection and Democratic Theory: Demand, Supply, and Life Tenure, 26 CARDOZO L. REV. 579 (2005) [hereinafter Resnik, Judicial Selection]; Judith Resnik, "Uncle Sam Modernizes His Justice": Inventing the Federal District Courts of the Twentieth Century for the District of Columbia and the Nation, 90 GEO. L.J. 607 (2002) [hereinafter Resnik, Inventing the District Courts]; Judith Resnik, Trial as Error, Jurisdiction as Injury: Transforming the Meaning of Article III, 113 HARV. L. REV. 924 (2000) [hereinafter Resnik, Trial as Error]; and Lane Dilg, From First Among Equals to Chief Executive Officer: The Powers and Duties of the Chief Justice of the United States (2005) (unpublished manuscript, on file with the Yale Law Library). Our thanks to current and former students Joseph Blocher, Marin Levy, Bertrall Ross, Laura Smolowe, Steven $\mathrm{Wu}$, and Sofia Yakren, and especially to Chinelo Dike and Emily Teplin who worked so ably on the recent drafts, to Gene Coakley and Camilla Tubbs for all their efforts to locate relevant materials, to Vicki Jackson, Linc Caplan, Theodore Ruger, Linda Greenhouse, Robert Post, and Albert Yoon for helpful comments, and, with great appreciation, to Denny Curtis, Russell Wheeler, and Paul Carrington for thoughtful readings of and comments on an earlier draft. Thanks are also due to Professors Stephen Burbank and Theodore Ruger, who shepherded the Symposium of which this contribution is a part, and to the editors of the University of Pennsylvania Law Review who hosted it. 
The reconfiguring of judicial power and structure within the federal system took place as, more generally, democratic mandates were reinterpreted to insist both that women and men of all colors had rights enforceable by courts and that the judiciary ought to include individuals diverse enough to capture an expanding class of litigants. Further, as concerns emerged about how, through popular electoral processes, individuals could entrench their authority for unduly long periods of time, American democracy revisited its institutions of electoral politics in the hopes (not yet well realized) of imposing constraints on the power of elected officials to entrench their own or their parties' power.

It is the interaction among these factors-the developing democratic principles, the long-held commitments to separation of powers and independent adjudication, and the new range of tasks accruing to the Chief Justice - that makes troubling the range of powers now possessed by the chief justiceship. One individual can serve for decades as a life-tenured administrator-adjudicator. With such tenure in office, one person has a unique opportunity to forward positions through two channels: by building a body of doctrine in case law and by building a set of policies in administrative directives.

When an individual is asked to be instrumental on behalf of the billion-dollar agency called "The Federal Courts" (with some two thousand judges, thirty thousand in staff, and hundreds of facilities) and also to be successful jurisprudentially as a disinterested adjudicator, one role cannot help but bleed into the other. Each role amplifies the power of, distracts from, and imposes costs on the other. Such conflation undermines democratic principles and the legitimacy of adjudication by giving the few individuals who hold the chief justiceship a disproportionate impact on American law.

The history of the developments of the twentieth century makes plain the plasticity of the packet of activities associated with the chief justiceship. Because the powers are artifacts of custom and statute rather than the Constitution, Congress as well as the Chief Justice can and should revisit these powers to revise the charter of that role. 


\section{TABLE OF CONTENTS}

I. RARE POWERS, UNDEREXAMINED 1577

II. AN ODD CONFIGURATION OF AUTHORITY ..................................... 1588

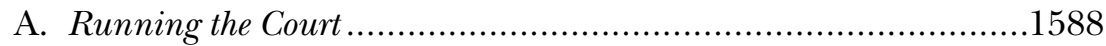

B. Running the Federal Judicial System, Itself Transformed ................1592

1. A New Federal Bureaucracy .............................................. 1594

2. Policymaking Through the Judicial Conference ................. 1599

3. Addressing the Nation........................................................... 1608

4. Lobbying the Congress....................................................... 1611

5. Appointing Judges to Special Courts and Committees........ 1615

C. Additional and Peculiar Powers:

From the Smithsonian to Garnishment..........................................1619

III. ThE ANOMALY OF LIFE-TENURED MUlti-TASKING ........................ 1621

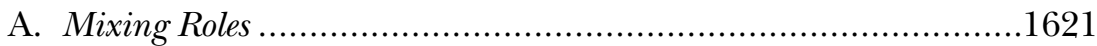

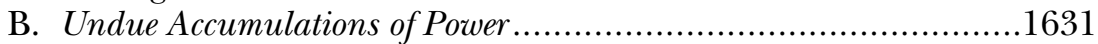

C. Representation Undermining Disinterest ...................................1634

IV. A CREATURE OF CONGRESS AND CUSTOMS, NOT THE CONSTITUTION

A. Constitutional Opportunities.

B. Statutory Innovations and Occasions for Self-Restraint

Appendix A: Tenure of Chief Justices of the United States,

of Directors of the Administrative Office of the U.S. Courts,

and of Directors of the Federal Judicial Center ....................................... 1650

Appendix B: Statutory Duties of the Chief Justice of the United States...... 1652

Appendix C: Tenure and Methods of Selection of State Chief Justices ....... 1658

\section{RARE POWERS, UNDEREXAMINED}

Chief justiceships turn over infrequently in the United States. The new Chief Justice is only the seventeenth person since the founding of the United States to hold that position. ${ }^{2}$ Academic conferences on the office of Chief Justice are similarly rare. The one predecessor to this Symposium, which was held in November of 2005 after the Senate confirmed Chief Justice John Roberts, occurred in 1982 when the University of Virginia convened a roundtable discussion while Warren Burger's chief justiceship was in full swing. ${ }^{3}$ More frequent conversations are in

\footnotetext{
${ }^{2}$ See infra Appendix A, Tenure of Chief Justices of the United States, of Directors of the Administrative Office of the U.S. Courts, and of Directors of the Federal Judicial Center, for a list of Chief Justices, running from John Jay, whose service began in 1789, through John G. Roberts, Jr., whose service began in 2005.

3 See The Office of Chief Justice 1 (White Miller Burkett Ctr. of Pub. Affairs 1984) [hereinafter THE OFFICE OF CHIEF JUSTICE]. Included in this volume is an ed-
} 
order in light of substantive changes in the portfolio of the Chief Justice, in the function of courts, and in democratic aspirations for adjudication.

This contribution is predicated on four points. Our first is to analyze the range of activities now undertaken by the Chief Justice. The content of the role of Chief Justice stems not from the Constitution (which mentions the term only once, when discussing who presides in the event of an impeachment trial of the President) ${ }^{4}$ but from dozens of statutes enacted in an ad hoc fashion over many decades, from customs, and from the vision, decisions, and ambitions of those who have held the office of the Chief Justice.

Many facets of today's chief justiceship are relatively new and not well known. In earlier eras, the Court relied on long oral arguments rather than briefs; the Chief Justice did not—as happens today-cut advocates off mid-sentence at the end of thirty minutes. ${ }^{6}$ Moreover, when defending the judiciary from attack, Chief Justice John Marshall resorted to a nom de plume; ${ }^{7}$ today, the Chief Justice makes such arguments in an annual year-end report and in remarks before public forums such as the American Bar Association and the American Law Institute. ${ }^{8}$ The contemporary custom is that, when in the majority, the Chief Justice has the power to assign which Justice will write the Court's opinion, ${ }^{9}$ with a circulation of drafts following thereafter. In contrast, Chief Justice Marshall appears to have written most of "the Court's" decisions, ${ }^{10}$ and the

ited transcript of discussions had at the 1982 Conference. See Conference on the Office of Chief Justice [hereinafter 1982 Virginia Conference], reprinted in THE OFFICE OF Chief Justice 155; see also Daniel J. Meador, Preface to THE OfFICE OF ChIEF Justice 157, 157 (introducing the volume and describing the conference); Peter G. Fish, The Office of Chief Justice of the United States: Into the Federal Judiciary's Bicentennial Decade [hereinafter Fish, Office of Chief Justice], in THE OFFICE OF CHIEF Justice 1 (describing at length the powers and duties of the Chief Justice at that time).

${ }^{4}$ See U.S. CONST. art. I, § 3, cl. 6 ("The Senate shall have the sole Power to try all Impeachments. ... When the President of the United States is tried, the Chief Justice shall preside: And no Person shall be convicted without the Concurrence of two thirds of the Members present."); see also infra notes 261-63 and accompanying text.

${ }^{5}$ See infra Appendix B, Statutory Duties of the Chief Justice of the United States; infra Part II.

${ }^{6}$ See Charles F. Hobson, Defining the Office: John Marshall as Chief Justice, 154 U. PA. L. REV. 1421 (2006).

${ }^{7}$ See id. at 1446 (referring to Marshall's newspaper essays defending the Court).

${ }^{8}$ See infra Part II.B.3.

${ }^{9}$ See Paul J. Wahlbeck, Strategy and Constraints on Supreme Court Opinion Assignment, 154 U. PA. L. REV. 1729 (2006); see also S. Sidney Ulmer, The Use of Power in the Supreme Court: The Opinion Assignments of Earl Warren, 1953-1960, 19 J. PUB. L. 49, $66-67$ (1970) (arguing that Chief Justice Warren did not assign opinions equally among the colleagues who joined him in majorities and further that, in controversial and close cases, he often chose not to write the majority's opinion).

${ }^{10}$ See Hobson, supra note 6, at 1445. 
other Justices may or may not have seen the texts that are now read as constituting their judgments. ${ }^{11}$

These aspects of the chief justiceship stem from the Chief's service as the chief executive officer (CEO) of the Supreme Court. Another set of tasks derives from service as the leader of the federal judiciary more generally. One hundred years ago, that job was much smaller. The federal courts themselves had both fewer judges and a smaller aegis; some one hundred federal judges, scattered across the nation, generally relied on the procedural rules of the different states in which they sat and looked to the Department of Justice as their spokesperson in Congress to present the judiciary's needs for staff and facilities.

Today, some two thousand judges populate the federal courts and share a set of national procedural rules that link their daily practices. These judges are supported by their own Administrative Office, some thirty thousand personnel working in more than eight hundred facilities around the United States, and funded by a budget in excess of five billion dollars annually. ${ }^{12}$ In addition to dealing with more than three hundred forty thousand civil and criminal filings, ${ }^{13}$ about sixty thousand appeals, ${ }^{14}$ as well as approximately a million and a half bankruptcy petitions annually, ${ }^{15}$ resulting in thousands of decisions by district, magis-

${ }^{11}$ See G. Edward White, The Internal Powers of the Chief Justice: The Nineteenth-Century Legacy, 154 U. PA. L. REV. 1463, 1471 (noting that the "only people who would have access to the opinions of the Court accompanying dispositions of cases were the author of those opinions and the Court's reporter," and that " $[t]$ he legal justifications advanced in Marshall Court opinions were thus typically the product of only one Justice"); see also $i d$. at 1476 (noting the lack of evidence that the assignment system used today was in place). For a discussion of the development of dissents and other changes in the Court's practices, see Robert Post, The Supreme Court Opinion as Institutional Practice: Dissent, Legal Scholarship, and Decisionmaking in the Taft Court, 85 MINN. L. REv. 1267, 1309-55 (2001).

${ }^{12}$ U.S. Courts Home Page, Administrative Office of the United States Courts, http://www.uscourts.gov/understanding_courts/89916.htm (last visited Apr. 6, 2006).

${ }^{13}$ Table C: U.S. District Courts-Civil Cases Commenced, Terminated, and Pending During the 12-Month Periods Ending March 31, 2004 and 2005, http://www.uscourts.gov/caseload2005/tables/C00mar05.pdf (last visited Apr. 5, 2006); Table D: U.S. District Courts-Criminal Cases Commenced, Terminated, and Pending During the 12-Month Periods Ending March 31, 2004 and 2005, http://www.uscourts.gov/caseload2005/tables/D00Cmar05.pdf (last visited Apr. 5, 2006).

${ }^{14}$ Table B: U.S. Courts of Appeals-Appeals Commenced, Terminated, and Pending During the 12-Month Periods Ending March 31, 2004 and 2005, http://www.uscourts.gov/caseload2005/tables/B00mar05.pdf (last visited Apr. 5, 2006).

${ }^{15}$ Table F: U.S. Bankruptcy Courts-Bankruptcy Cases Commenced, Terminated, and Pending During the 12-Month Period Ending March 31, 2004 and 2005, 
trate, and bankruptcy judges, ${ }^{16}$ the federal judiciary has also become an educational institution (teaching judges) and a policy-making body (advising Congress).

The development of a greater institutional presence for the federal judiciary has resulted in a larger set of powers accruing to the Chief Justice. The expansion of the federal courts is tied to the growth of a national lawmaking regime in which Congress played a pivotal rolecrafting legal regimes that placed demands on the federal courts. Several Chief Justices-most notably William Howard Taft, Earl Warren, Warren Burger, and William Rehnquist-deserve significant credit for carving out new authority, for proposing and obtaining funds for new institutional structures, and for successfully persuading the other branches to support their visions. ${ }^{17}$ Most recently, under the guidance of Chief Justices Burger and Rehnquist, the federal judiciary has worked out an integrated programmatic agenda, advancing positions in Congress about the allocation of power between the state and federal systems, between life-tenured and non-life-tenured federal judges, and about rights of access to courts. These administrative proposals reflect the commitments of those Chief Justices to a limited role for federal constitutional, statutory, and common law rights-views they also espoused in judgments of the Supreme Courts that they led.

Our second point requires a shift in focus from the federal judiciary's internal development to the revamping of other government practices and constitutional commitments. The thickening ranks within the judiciary are paralleled in the other branches, as new agencies, congressional committees, and executive departments have come into being. In all branches, the elaboration of bureaucratic structures has been accompanied by a concomitant delegation of tasks to staff. In addition, new roles and expectations for adjudication have emerged. From governments of emperors and kings to republican city-state burghers, adjudica-

http://www.uscourts.gov/caseload2005/tables/F00mar05.pdf (last visited Apr. 5, 2006).

${ }^{16}$ For statistics on matters disposed of by magistrate judges, as well as other duties performed by magistrate judges, see Judicial Business of the United States Courts, Table S-17: Matters Disposed of by U.S. Magistrate Judges During the 12-Month Periods Ending September 30, 1994, and September 30, 2000 Through 2004, http://www.uscourts.gov/judbus2004/tables/s17.pdf (last visited Apr. 5, 2006).

17 See generally ROBERT J. STEAMER, CHIEF JUSTICE: LEADERSHIP AND THE SUPREME COURT (1986); Fish, Office of Chief Justice, supra note 3; Judith Resnik, Constricting Remedies: The Rehnquist Judiciary, Congress, and Federal Power, 78 IND. L.J. 223 (2003) [hereinafter Resnik, Constricting Remedies]; William F. Swindler, The Chief Justice and Law Reform, 1921-1971, 1971 SuP. CT. Rev. 241 (1971); Edward A. Tamm \& Paul C. Reardon, Warren E. Burger and the Administration of Justice, 1981 BYU L. REV. 447 (1981). 
tion has long been an important part of the exercise of political authority. ${ }^{18}$ But until recently, many of those governed had few juridical rights and were not permitted to be litigants, lawyers, or judges. Further, governments were not obliged to disclose their own activities and could not often be held to their own promises. Judges served at the pleasure of the rulers who empowered them.

Over centuries, democratic countries came to appreciate the need for judicial independence, translated as a requirement that jurists have some degree of separation from, rather than be subject directly to, the political control of executive and legislative authorities. Furthermore, whole new sets of claimants-women and men of all colors and classeshave gained the power to insist in courts on fair treatment from their governments, which are, in turn, obliged to explain their actions. As new rights-holders gained competency to enforce rights through courts, the idea emerged that judiciaries ought to include individuals diverse enough to capture the expanded array of participants. In eras when only men had juridical authority and in countries in which only whites had legal standing, judges were drawn exclusively from those pools. In the contemporary world, where democratic commitments oblige equal access to power by persons of all colors whatever their gender and wherever they live, the composition of a judiciary-if all-white or all-male or all-upper class or all from one area of the country-becomes a problem of equality and legitimacy.

In many countries, "diversity" (variously defined to include geography, expertise, and knowledge, as well as the demographic characteristics of jurists) is now a dimension of governments' aspirations, and this concern has affected judicial selection processes in many democracies. For example, by statute, Canada has a set-aside ensuring that its highest Court includes three Justices from Quebec, ${ }^{19}$ therefore well-versed in the civil law regime of that province (and likely to be francophones). ${ }^{20}$ The Treaty of Rome that chartered the International Criminal Court requires

${ }^{18}$ See, e.g., John H. Langbein, Prosecuting Crime in the Renaissance: EnGLAND, Germany, France (2005); Judith REsnik \& DenNis E. Curtis, Representing Justice: From Renaissance ICONOGRAPHY TO 21st Century COURTHOUSES, The Henry Jayne LaBarre Lecture, American Philosophical Society (Nov. 12, 2005) (copy on file with the University of Pennsylvania Law Review).

${ }_{19}^{19}$ See Supreme Court Act, R.S.C., ch. S-26, s. 6 (1985) (Can.).

${ }^{20}$ Conventions supporting geographical diversity have also developed, with more Justices coming from the provinces with higher populations. The expectation is that, of the remaining six Supreme Court jurists, three come from the Province of Ontario, one each from the Western and Northern Provinces, and one from the Maritimes. See Supreme Court of Canada: Current Judges, http://www.scc-csc.gc.ca/AboutCourt/ judges/curjudges_e.asp (last visited Apr. 5, 2006). 
countries nominating judges to "take into account" the need for jurists with expertise in relevant bodies of law and to select jurists providing "representation of the principal legal systems of the world," "[e]quitable geographical representation," and "[a] fair representation of female and male judges." ${ }^{21}$

Moving inside the United States, within the federal system, selection processes for magistrate judges call for seeking applications from all qualified persons, with reference to "women, members of minority groups and individuals with disabilities." ${ }^{22}$ Delaware provides that its $\mathrm{Su}-$ preme Court include jurists of different political parties, ${ }^{23}$ while other

${ }^{21}$ Rome Statute of the International Criminal Court, art. 36(8) (a) (i)-(iii), July 17, 1998, 2187 U.N.T.S. 90. The Treaty requires that the Court consist of at least eighteen judges, $i d$. art. 36(1), (2) (a), with no two being "nationals of the same State." Id. art. 36(7). Article 36(3) calls on state parties to nominate persons either with "established competence in criminal law and procedure," id. art. 36(3) (b) (i), or with "established competence in relevant areas of international law such as international humanitarian law and the law of human rights," $i d$. art. 36(3)(b)(ii). Nominees are then put onto two lists, representing criminal law and international law (a nominee can be listed on both), from which State Parties make selections by secret ballot. Id. art. 36(5)-(6) (a). When voting, State Parties must take into account diversity of nationality, geography, and representation of men and women; that obligation has been implemented through a weighted voting system that requires each State Party to vote for a minimum number of candidates from specified regional groups and a minimum number of male and of female candidates. See Procedure for the Nomination and Election of Judges of the International Criminal Court, Annex 1, Res. ICC-ASP/3/Res. 6, § B(20) (b)-(c) (Sept. 6, 2004) available at http://www.icc-cpi.int/library/asp/ICC-ASP-4S4-English.pdf. Additionally, State Parties are to take into account the need for "judges with legal expertise on ... violence against women and children.” Id. § B(19). See generally Cate Steains, Gender Issues, in THE InTERnATIONAL Criminal Court: THE MAKInG of THE Rome STATUTE 357 (Roy S. Lee ed., 1999).

${ }^{22}$ Admin. OfFice Of THE U.S. COURTS, THE SELECTION, APPOINTMENT, AND REAPPOINTMENT OF United STATES MAGistrate JUdGES 11 (2002) ("To attract the greatest number of applicants, the public notice for a new appointment should be disseminated as widely as practicable so that all qualified members of the bar are aware of the opportunity to apply for the position. The court should encourage applications from all qualified persons including women, members of minority groups and individuals with disabilities who can perform the essential functions of the position. Consistent with the above, the court should consider transmitting the public notice to state and local bar associations and interest groups that focus on minorities."); see also Regulations of the Judicial Conference of the United States for the Selection, Appointment, and Reappointment of United States Bankruptcy Judges (promulgated by the Judicial Conference Mar. 2001), available at http://www.ca5.uscourts.gov/news/vacancies/ qualif.pdf (calling upon merit selection panels to "make an affirmative effort to identify and give due consideration to all qualified candidates, without regard to race, color, age (over 40), gender, religion, or national origin").

${ }^{23}$ DEL. CONST. art. $4, \S 3$ ("Three of the five Justices of the Supreme Court in office at the same time, shall be of one major political party, and two of said Justices shall be of the other major political party."). This provision was added to the Delaware Constitution in 1978, when that Constitution was amended to add two additional justices to the state supreme court. See 61 Del. Laws 1638 (1978). 
states make provisions for commissions nominating judges to have membership reflective of the diversity within their populations. ${ }^{24}$

Pressures to change the demography of those serving as judges have also affected methods for judicial selection, with calls for democraticizing the process mounting in several countries. In England and Wales, reforms of the Office of Lord Chancellor and the creation of a new Supreme Court have been coupled with the establishment of a commission to make recommendations for judicial appointments. ${ }^{25}$ And, in Canada, after hearings in the House of Commons in 2004, the Attorney General promised to open the process of gathering nominations and of vetting potential appointees. ${ }^{26}$

${ }^{24}$ See, e.g., ALASKa CONST. art. 4, $\$ 8$ (requiring that appointments to the state's Judicial Council be made with "due consideration to area representation and without regard to political affiliation"); IOWA CONST. art. 5, § 16 (requiring that "[d] ue consideration shall be given to area representation in the appointment and election of judicial nominating commission members"); FLA. STAT. ANN. § 43.291 (West 2005) (stating that the membership of the state's judicial nominating commission should to the extent possible "reflect[] the racial, ethnic, and gender diversity, as well as the geographic distribution, of the population within the territorial jurisdiction of the court for which nominations will be considered"); IOWA CODE ANN. § 46.1 (West 2005) (providing that " $[\mathrm{n}] \mathrm{o}$ more than a simple majority of the members [of the state's judicial nominating commission] shall be of the same gender"); see also ARIZ. CONST. art. 6, $\S 36$.A (stating that the governor shall appoint ten nonattorney members to the state's commission on appellate court appointments and that, to make such appointments, the governor shall appoint a nominating committee, the makeup of which "shall, to the extent feasible, reflect the diversity of the population of the state").

${ }^{25}$ See Constitutional Reform Act, 2005, c. 4, pt. 3, § 26(5) (Eng.) (requiring that a commission select a recommended candidate); id. c. 4, pt. 4, c. 1, §61 (establishing the Judicial Appointments Commission).

${ }^{26}$ See Press Release, Minister of Justice and Attorney General Irwin Cotler, Canada Department of Justice, New Supreme Court of Canada Appointments Process Launched (Aug. 8, 2005), available at http://canada.justice.gc.ca/en/news/nr/2005/ doc_31586.html (announcing a new three-step appointment process for the Supreme Court of Canada that requires input from civic leaders, members of the legal community, and territorial representatives in order to "ensur[e] greater transparency, increased public involvement and meaningful Parliamentary input"). The Liberal Party, then in power, came to focus on revamping procedures for judicial selection in part due to controversies unrelated to the judiciary. Academics had for some time criticized the appointments process for its centralization of authority and lack of transparency. See, e.g., Jacob S. Ziegel, Merit Selection and Democratization of Appointments to the Supreme Court of Canada, CHOICES: CTS. \& LEGISLATURES, June 1999, at 1, 16, available at http:///www.irpp.org/choices/archive/vol5no2.pdf (discussing criticisms of the confirmation process for the Supreme Court of Canada). But change did not occur until 2004, when a Prime Minister, facing reelection, sought to distance himself from an investigation into corruption (the "sponsorship scandal") and as groups, objecting to Canadian courts' decisions protecting same-sex marriage, used criticisms of the selection process as an argument for more public engagement with judicial candidates. See Kathleen Harris, PM Is 'Mad as Hell': Scandal Sends Liberals Spiralling in Polls, TO- 
Insisting on input from more sources is one kind of constraint on executive prerogatives. Another is limiting the tenure of individuals who hold office. Many democracies do so for judges through mandatory retirement or fixed terms of service. ${ }^{27}$ In the United States, efforts to limit the power of the individual serving as President came in the form of a constitutional amendment imposing a two-term limit. ${ }^{28}$ Interest in constraining power can also be seen in campaign finance reforms, which seek to respond (though not yet well) to the ability of individuals, using electoral processes, to entrench their and their parties' authority.

Our third point derives from the interaction of the first two. Given distrust of undue concentrations of power in one person and increased interest in including multiple perspectives in decisionmaking, the recently expanded (but now seen as customary) repertoire of powers of the Chief Justice becomes troubling. While the current Chief Justice is only the seventeenth individual in that line, the current President of the United States is the forty-second person to hold that office. ${ }^{29}$ Thus, the unexamined practice that the Chief Justice holds that position until voluntarily relinquishing it reduces the number of individuals who chair the Court-decreasing the range of persons who can take on the most visible role within the federal judiciary while enabling the centralization of power for decades in a single person.

Other problems stem from the amalgam of responsibilities accruing to the chief justiceship. The person holding that position must divide time between the demands on a Justice and the obligations of a senior administrator. As a jurist, the Chief Justice works on a docket assumed to require the full-time attention of the other Justices on the Court. While Associate Justices regularly take on the occasional speech, the visiting lectureship, or the writing of a book, all of these projects are episodic and typically can be deferred under the press of the Court's business. In

RONTO SUN, Feb. 15, 2004, at 4; Kim Lunman, MPs Working on Hearings for Top-Court Nominees, GLOBE \& MAIL, Aug. 23, 2004, at A4.

In 2006, under a new Prime Minister from another party, a proposed nominee was chosen and, for the first time in Canada's history, presented to Parliament, whose members were permitted to ask limited questions in a televised hearing. See Sean Gordon, Top Court Nominee Hints at Limited Role, TORONTO STAR, Feb. 28, 2006, at A1.

${ }^{27}$ See infra notes 242-48 and accompanying text.

${ }^{28}$ U.S. CONST. amend. XXII, § 1 ("No person shall be elected to the office of the President more than twice ....").

${ }^{29}$ President George W. Bush is known as the forty-third President but is the fortysecond person to hold that office; President Grover Cleveland served two nonconsecutive terms. See John J. PAtrick, Richard M. Pious, \& DONAld A. Ritchie, Oxford GuIDE TO THE UNITED STATES GOVERNMENT 742-43 (2001). 
contrast, as an administrator, the Chief Justice has a range of obligatory and relentless duties.

Even with significant delegation, oversight is required. Yet both the Chief Justice and those to whom leadership is delegated are largely sheltered from public view, thereby creating an administrative authority free of many of the constraints imposed on other agencies and offices. That insulation is attractive, when the focus is on the role of the Chief Justice as a jurist. The point of lengthy tenure is to enhance the ability to render decisions without fear of repercussions, and specifically, of being fired. Current as well as historical examples make plain that the drafters of the United States Constitution were right to try to protect judges from political retribution by interests both public and private. ${ }^{30}$

But the administrative portfolio currently held for life by the Chief Justice cannot find its justification in the rationales protecting adjudica-

${ }^{30}$ Indeed, whether the United States has done enough is a matter of debate. One dimension of the underprotection of the federal judiciary is its funding. During much of the twentieth century, the American Bar Association argued that federal judicial salaries were too low. Some judges have also sued, arguing that a few congressional enactments that did not provide for protection of benefits or for cost-of-living increases violated the constitutional protection against diminution of judicial salaries. See, e.g., Williams v. United States, 240 F.3d 1019, 1023 (Fed. Cir. 2001) (rejecting the claim of a class of judges that legislation denying cost-of-living pay increases to federal judges violated Article III's Compensation Clause), cert. denied, 535 U.S. 911 (2002) (Breyer, J., joined by Justices Scalia and Kennedy, dissenting); see also AM. BAR Ass'N \& FED. BAR Ass'N, Federal Judicial PAy ERosion: A RePORT On THE NEEd FOR REFORM (2001), available at http://www.abanet.org/poladv/fedjudreport.pdf. In addition to salaries, another concern is funding for facilities and administration. See Fiscal 2005 Appropriations: Commerce, Justice, State: Hearing Before the Subcomm. on Commerce, Justice, State, the Judiciary and Related Agencies of the H. Comm. on Appropriations, 108th Cong. 2-11 (2004), available at http://www.uscourts.gov/Press_Releases/heyburn021904.pdf (statement of Hon. John G. Heyburn II, Chairman, Comm. on the Budget of the Judicial Conf. of the United States) (raising concern about the "crisis" facing the federal courts in light of the appropriations planned).

In contrast to the centrality of legislative decisions in the U.S. system, the Canadian Supreme Court has concluded that the setting of amounts for judicial compensation should occur through methods less dependent on the will of a sitting parliament. See Reference on Remuneration of Judges of the Provincial Court, 3 S.C.R. 3, 94-117 (Can. 1997). Some state courts have explored a similarly doctrinal position. See G. Gregg Webb \& Keith E. Whittington, Judicial Independence, the Power of the Purse, and Inherent Judicial Powers, 88 JUDICATURE 12, 14-18 (2004) (describing an expanding doctrine of inherent judicial power to require financing and discussing a $2002 \mathrm{Kansas} \mathrm{Su}-$ preme Court order requiring an increase in fees to provide funds).

Another concern is that Article III is currently interpreted as protecting only those judges chartered through its provisions. Hundreds of persons-called magistrate, bankruptcy, and administrative law judges-hold federal adjudicatory power but are not, under current doctrine, sheltered by the protections of Article III. See Judith Resnik, Judicial Independence and Article III-Too Little and Too Much, 72 S. CAL. L. REV. 657, 657-66 (1999). 
tors from inappropriate oversight. Rather, the packet of powers now encapsulated in the chief justiceship undermines judicial independence by embedding the judiciary in a series of instrumental agendas (some of which may well be appropriate, from administrative perspectives) that make their way into legislation and then return to the Court as legal questions to be adjudicated. As Chief Justice Charles Evans Hughes warned decades ago, ${ }^{31}$ when judges become identified with programmatic goals, questions emerge about the relationship between the judgments rendered in adjudication and the goals espoused in administration. Perhaps if federal judges lacked the power of judicial review, a form of pre-enactment advice could be useful. But today's system of double dipping-giving advice ex ante and providing adjudication ex post-offers the organized judiciary opportunities to influence legislation that federal courts will later be obliged to evaluate.

If one kind of criticism is that the judiciary ought not take on that kind of advisory role, another addresses the representative function taken on by the Chief Justice and the judiciary's policy-making body. Do the hundreds of sitting federal judges all subscribe to certain propositions? Presumably all want safe workplaces, reasonable compensation, help from support staff, and the protection of judicial independence, albeit differently interpreted. ${ }^{32}$ And certainly "the judiciary," writ large, has a professional obligation to advance the rule of law and to provide justice fairly administered. But beyond these general propositions, the judiciary is not supposed to represent any particular approach to social and political ordering, in order that it may serve as a disinterested adjudicator when conflicts emerge between special interest groups.

But the leadership of the federal judiciary has not limited its input to abstract commitments to justice or to the practical needs of more judges and support services. Rather, as is detailed below, under Chief Justices Burger and Rehnquist, the Judicial Conference of the United States (the judiciary's policy-making body) advised Congress not to create new federal rights enforceable in federal court and to reallocate a good deal of federal adjudicatory power to non-Article III judges. Furthermore, in

\footnotetext{
${ }^{31}$ See Resnik, Trial as Error, supra note 1, at 961-63; Theodore W. Ruger, The Judicial Appointment Power of the Chief Justice, 7 U. PA. J. CONST. L. 341, 386-87 (2004); infra notes 223-32 and accompanying text.

${ }^{32}$ For example, in Republican Party of Minnesota v. White, 536 U.S. 765 (2002), the Court split five to four over the enforceability of a regulation limiting the kinds of statements to be made by judicial candidates for elected office; whether the regulation violated the First Amendment was debated in the context of disagreements about the appropriate posture of judges, the meaning of judicial "impartiality," and the kind of campaign claims that candidates for judicial office could make.
} 
speeches to the nation, these Chief Justices often suggested that their own approaches and prescriptions were institutional rather than personal-as if "the Article III judiciary" could (and should) speak in a unified voice about topics such as the import of federalism or the classes of litigants to whom Congress should grant rights of access to the federal courts.

Our critique is not founded on standard objections to the "undemocratic" power of the judiciary, sometimes described as the "countermajoritarian difficulty" about which constitutional theorists have puzzled. ${ }^{33}$ Our position is that adjudication is a form of democratic ordering, and, when judicial power is exercised within the confines of adjudication, the resulting judgments provide one appropriate avenue for realizing the range of commitments in a constitutional democracy.

Nor is our premise that law is separate from politics. Instead, precisely because law expresses a form of politics, because rights of access to courts endow certain individuals with the ability to forward yet other political goals through law, and because judges—when adjudicating-have to make judgments that determine which persons have what rights and remedies, the judiciary as an institution should be chary of taking on too many nonadjudicatory roles and, in particular, ought to abstain from weighing in on the question of who among us ought to be given new rights and remedies in courts. Its leadership ought not to suggest that "the Federal Courts" have, as a corporate body, opted for one of several competing approaches to these basic questions that have occupied the American legal regime from its inception. The more frequent the exercise of a corporate judicial voice on such issues, the less the judiciary retains its character as an institution issuing judgments predicated on, constrained by, and tethered to the records of specific cases.

Our fourth and final point is to address the question of what kinds of changes are constitutionally permissible and pragmatically appealing. Because the powers of the Chief Justice are artifacts of custom and statute rather than the Constitution, revisiting the practices that have so enlarged the Chief Justice's charter is possible. Further, because these powers are problematic from the various standpoints outlined above, reconsideration is appropriate and necessary. The new Chief Justice could - as he may be doing - use the occasion of this change in leader-

${ }^{33}$ See, e.g., JOHn Hart Ely, Democracy AND Distrust: A TheOry OF Judicial REVIEW 4-5 (1980) (offering an analysis of the "central function" and "at the same time the central problem[] of judicial review: a body that is not elected or otherwise politically responsible in any significant way is telling the people's elected representatives that they cannot govern as they'd like"). 
ship as an opportunity to reconfigure its parameters. ${ }^{34}$ In addition, statutory revisions are in order to reduce the eclectic array of duties assigned to the Chief Justice. Most importantly, the Chief Justice ought not to have the power to assign individual judges to subject-matter-specific courts or to chair the Judicial Conference of the United States. In addition to altering the statutory powers of the chief justiceship, new legislation is needed to impose term limits, so that more people with a variety of skills and views are able to hold the office. ${ }^{35}$

These interventions are responsive to contemporary problems but ought not to be seen as a structure that will necessarily endure throughout the next century. The history of the federal courts and of the Office of Chief Justice is replete with examples of change, driven by a mixture of what is politically plausible and useful. ${ }^{36}$ The powers that reside in the chief justiceship now pose a problem for democracy that ought to be addressed by various institutions of government, and whatever judgments are made at this juncture will, in time, need to be revisited.

\section{AN ODD CONFIGURATION OF AUTHORITY}

\section{A. Running the Court}

A few facts help to underscore the distance between the role played by a Chief Justice of a Supreme Court that in its early years camped out with a small number of helpers in makeshift quarters on the ground floor of the Capitol, ${ }^{37}$ and the role that the Chief Justice now plays as the Court works in the imposing 1935 Cass Gilbert building. Today's Supreme Court has a staff of over four hundred fifty and a budget of more than sixty million dollars annually. ${ }^{38}$ The Chief Justice is the senior offi-

${ }^{34}$ See infra note 311 and accompanying text.

${ }^{35}$ Others have proposed that all Supreme Court Justices' terms be limited. See generally REFORMING THE COURT: TERM LIMITS FOR SUPREME COURT JUSTICES (Roger C. Cramton \& Paul D. Carrington eds., 2006) [hereinafter REFORMING THE COURT].

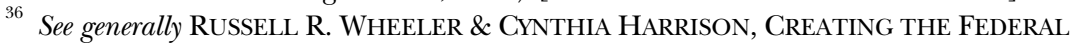
JUDICIAL SYSTEM (3d ed. 2005) (1989) (providing an overview of those developments and excellent diagrams detailing the expansion of the federal judicial system). The classic history of the federal courts through the Taft era is FELIX FRANKFURTER \& JAMES

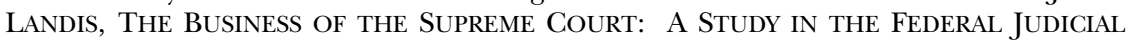
SYSTEM (1927).

37 See Robert L. Stern, Eugene Gressman, Stephen M. Shapiro, \& Kenneth S. Geller, Supreme COURT Practice 7-8 (8th ed. 2002) (detailing the Court's various quarters prior to 1935); The Supreme Court-Its Homes Past and Present, 27 A.B.A. J. 283, 283-89 (1941) (describing the same and including pictures).

38 See U.S. OfFICE OF MGMT. \& BUdGeT, BudGET OF THE U.S. GOVERNMENT, FiscAL YEAR 2007-APPENDIX, at 49-50, available at http://www.whitehouse.gov/omb/budget/ fy2007/pdf/appendix/jud.pdf. 
cial on the Court. As Peter Fish well described in the $1980 \mathrm{~s},{ }^{39}$ that position puts the Chief Justice in charge of a diverse array of activities, from admitting lawyers to the bar of the Supreme Court to policing the public and the private sessions of the Court. ${ }^{40}$ The Chief Justice plays a role in generating norms about the time allotted for arguments, the shape and pace of discussions, and the scheduling of cases accepted for consideration. ${ }^{41}$

As lawyers who seek Court review know well, the Court also promulgates its own, special rules of practice, again under the superintendence of the Chief Justice. ${ }^{42}$ Moreover, unlike the rulemaking that governs the practices and procedures of the lower courts, the Supreme Court does so free of statutory obligations for public notice and comment and of requirements that Congress have time to consider rules before they become effective. ${ }^{43}$

${ }^{39}$ Fish, Office of Chief Justice, supra note 3, at 19-36.

${ }^{40}$ The administrative aspects of the chief justiceship may obscure the intellectual leadership of some Chief Justices in altering the Court's jurisprudence. Steamer has also noted the importance of the Chief Justice's ability to "mass the Court" (a phrase he attributed to Taft). See STEAmER, supra note 17, at 8.

${ }^{41}$ See Alan B. Morrison, Opting for Change in Supreme Court Selection, and for the Chief Justice, Too, in REFORMING THE COURT, supra note 35, at 203, 219-21 (discussing Chief Justice Rehnquist's influence on the scheduling and acceptance of cases).

${ }^{42}$ See 28 U.S.C. $\$ 2071$ (a) (2000) (providing that the Supreme Court and the lower courts shall prescribe rules for the conduct of their business).

${ }^{43}$ See id. $\$ 2071$ (b) (providing that "any rule prescribed by a court, other than the Supreme Court ... shall be prescribed only after giving appropriate public notice and an opportunity for comment"). The Court's rule-making procedures have changed over time. In the early days, the Clerk catalogued orders, collected chronologically with amendments added periodically. Beginning in the middle of the twentieth century, Chief Justices added structure to the process: Chief Justice Fred Moore Vinson by creating a committee of Justices to review the Court's rules, Chief Justice Warren by designating a group of lawyers to serve as advisors, and Chief Justice Rehnquist by appointing members of the Court to a rules subcommittee that, on some occasions, has published draft rules circulated for public comment before their adoption. See Bennett Boskey \& Eugene Gressman, Supreme Court Rules: The 2003 Revisions, 213 F.R.D. 505, 506 (2003) (describing the rule-making process under Chief Justice Rehnquist); Frederick Bernays Wiener, The Supreme Court's New Rules, 68 HARV. L. REV. 20, 38-39 (1954) (describing the 1952 appointment of a committee of Justices by Chief Justice Vinson, as well as Chief Justice Warren's subsequent request that a "representative group of attorneys" convene to provide advice to the Court's committee); see also William H. Allen \& Alex Kozinski, Rules of the Supreme Court of the United States, 94 HARV. L. REV. 312, 312 (1980) (book review) (reviewing the Court's 1980 Rules, which arrived "with little fanfare ... [and] had the immediate effect of depreciating every practitioner's investment" in an authoritative manual of the Court's rules); Kenneth S. Geller \& Mark I. Levy, Rules for the 90s: Revision to High Court Procedures, A.B.A. J., Apr. 1990, at 70, 70 (1990) (noting that the Court provided "no explanation of the background and purposes of the new rules" nor did it comment on changes). 
The Chief Justice is also the executive manager of the Court. From supplies for and maintenance of the building to its staff, their holiday parties, and relations with the media, the Chief Justice either takes control or assigns such responsibilities to others. ${ }^{44}$ The federal statutes that create the offices of the Court's clerk, reporter, library, archivist, and curator give oversight responsibilities to the Chief Justice. ${ }^{45}$ Much of this daily work is delegated to others and, since Warren Burger's tenure, to an Administrative Assistant appointed by and reporting directly to the Chief. $^{46}$ The Chief Justice is also charged with the sad task of certifying the disability of Justices. ${ }^{47}$ And, the Chief is the diplomatic host for the Court as it welcomes foreign jurists, members of the national and state governments, and the public.

While many such duties are predicated on statutes, others arise from customs that, as other contributions detail, ${ }^{48}$ have changed over time. Ready examples of the fluidity come from the tenure of William Rehnquist, who undertook some tasks with a flair that generated news. He added colored stripes to his robe, ${ }^{49}$ convened what he termed "Christmas" parties, ${ }^{50}$ kept a fast pace for the Court's conferences, and

When making two revisions effective in 2005, the Court did not provide opportunities for notice and comment. See Bennett Boskey \& Eugene Gressman, Supreme Court Rules: Minor 2005 Changes, 228 F.R.D. 262, 262 (2005) (supporting the "usefulness of the Court's adopting and following a practice" of enabling public comment but noting that "minor changes" that "almost inevitably" flow from extant rules may appropriately be exempted).

${ }^{44}$ For example, Steamer reports that Chief Justice Burger oversaw the remodeling of the bench to create an arrangement that permitted the Justices, formerly seated in a straight line, to see each other; Burger also ordered that the inside of the Court's fountains be painted blue. STEAMER, supra note 17, at 178 .

45 The Court's Clerk, Marshal, Reporter, and Librarian are provided for by statute. See 28 U.S.C. $\$ \S 671-674$ (2000). Under these provisions, those appointments are made by the Supreme Court, with the Chief Justice designated to approve the "necessary assistants and messengers" for the Clerk's Office, $i d$. § 671(c), "necessary assistants and other employees" for the Marshal's Office, $i d$. $\$ 672$ (b), "necessary professional and clerical assistants and other employees" for the Reporter, id. §673(b), and "necessary assistants" for the Librarian, id. $\$ 674(\mathrm{~b})$. Further, the Chief Justice approves the Marshal's regulations for the building, 40 U.S.C. $\$ 6102$ (2000 \& Supp. II 2002), and the Marshal's regulations for policing the building, id. $\S 6121$.

${ }^{46}$ See 28 U.S.C. $\$ 677$ (a)-(b) (2000).

${ }^{47}$ See id. $\$ \$ 371-372$.

${ }^{48}$ See Linda Greenhouse, How Not To Be Chief Justice, 154 U. PA. L. REV. 1365 (2006); Hobson, supra note 6; Natalie Wexler, In The Beginning: The First Three Chief Justices, 154 U. PA. L. REV. 1373 (2006); White, supra note 11.

${ }^{49}$ See Henry J. Reske, Showing His Stripes: Operetta Inspires Chief Justice To Alter His Robe, A.B.A. J., Mar. 1995, at 35, 35 (describing the four gold stripes that the Chief Justice added to his black robe in 1995).

${ }^{50}$ See Craig Timberg, Sing-along Strikes a Sour Note: Chief Justice's Selection of 'Dixie' Distasteful, Some Say, WASH. POST, July 22, 1999, at B1 (discussing songs chosen by the 
led the Court in a dramatic reduction of the number of cases docketed for decision. ${ }^{51}$ Associate Justice Ruth Bader Ginsburg captured the array of powers stemming from many sources when, in her statement mourning the death of Chief Justice Rehnquist, she described him as the "fairest, most efficient boss" she had ever had..$^{52}$ The appellation "boss" is an important addition to the more common accolade of the Chief Justice as the "symbol of the Court."

This sketch of a significant packet of powers should not be read as ignoring the constraints on that authority. The ability of the Chief Justice to "boss" colleagues and staff has its limits, some generic to managers and others specific to this job. Advice to business leaders regularly includes a reminder of their dependence on those who work for them. The Chief Justice is particularly reliant on collegial accord because many

Chief at the Fourth Circuit's Judicial Conference and also noting that "Rehnquist ha[d] been ... resisting calls for the Supreme Court's annual Christmas Party to be renamed a 'Holiday Party,' and that he led "the singing of several Christmas carols and had a 25-foot tree erected at the [C] ourt"); see also Tony Mauro, Roberts Adheres to Precedent on High Court Revelry, LAw.COM, Dec. 16, 2005, http://www.law.com/jsp/ newswire_article.jsp?id=1134641110755 (registration required, on file with the University of Pennsylvania Law Review) (describing the concerns raised in the late 1980s about the focus on "Christmas," Chief Justice Rehnquist's insistence on using that term, and the invitations issued under Chief Justice Roberts in 2005 to the annual "Christmas Recess Party").

${ }^{51}$ See Arthur D. Hellman, The Shrunken Docket of the Rehnquist Court, 1996 SUP. CT. REV. 403, 403 (1996) (providing data on the Court's plenary docket, which in the 1988 Term included oral arguments and a written decision in 147 cases and by the 1995 Term involved hearing and deciding only 77 cases).

${ }^{52}$ See Statement of Justice Ruth Bader Ginsburg, Statements from the Supreme Court Regarding the Death of Chief Justice William H. Rehnquist (Sept. 4, 2005), available at http://www.supremecourtus.gov/publicinfo/press/pr_09-04-05b.html (adding that "William H. Rehnquist used to great effect the tools Congress and tradition entrusted to him").

${ }^{53}$ See Nomination of Justice William Hubbs Rehnquist, Hearings Before the Committee on the Judiciary, United States Senate, on the Nomination of Justice William Hubbs Rehnquist To Be Chief Justice of the United States, 99th Cong. 1, 2 (1986) (opening statement of Chairman Strom Thurmond), reprinted in 12 THE SUPREME COURT OF THE UNITED STATES: HEARINGS AND REPORTS ON SUCCESSFUl AND UNSUCCESSFUl NOMINATIONS 312 (Roy M. Mersky \& J. Myron Jacobstein eds., 1989), available at http://www.gpoaccess.gov/ congress/senate/judiciary/sh99-1067/browse.html (follow "Chairman Strom Thurmond" hyperlink) (last visited Apr. 5, 2006) [hereinafter HEARINGS AND REPORTS]. At that hearing, Senator Edward Kennedy offered a parallel comment, that the Chief Justice "symbolizes the rule of law in our society; he speaks for the aspirations and beliefs of America as a Nation." Nomination of William H. Rehnquist To Be Chief Justice of the United States, Report from the Committee on the Judiciary, United States Senate, Together with Additional, Minority, and Supplemental Views, S. EXEC. REP. No. 99-18, at 14 (1986) (supplemental views of Sen. Edward M. Kennedy), reprinted in 12A HEARINGS AND REPORTS 1549 (follow "Hon. Edward M. Kennedy" hyperlink). 
with whom the Chief Justice works have life tenure. ${ }^{54}$ Further, because of strong norms of collegiality and a shared affection for the Court as an institution, the Chief Justice may be especially solicitous of the views of colleagues on the Court and in the lower federal judiciary. ${ }^{55}$ Astute Chief Justices carefully use their authority over opinion assignment ${ }^{56}$ and appointments to special courts and committees to forward agendas cooperatively and to appease dissenters. ${ }^{57}$ Of course, insiders can recount instances in which the Chief Justice was unable to achieve a particular outcome and, on occasion, outsiders also learn of discord within. ${ }^{58}$

\section{B. Running the Federal Judicial System, Itself Transformed}

The Constitution mentions a "Chief Justice" ${ }^{\text {59 }}$ but does not use today's term: "Chief Justice of the United States." Neither did the Judiciary Act of 1789, which described "a chief justice" joining "five associate justices" on the Supreme Court. ${ }^{60}$ At some point thereafter, the title "the

${ }^{54}$ As Justice William O. Douglas commented, the "Chief Justice has as associates men who are sovereign in their own right, not men picked, like Cabinet officers, to do his bid$\operatorname{ding}[;] \ldots$ his tact and persuasiveness are his only appeal." William O. Douglas, Earl Warren-A Tribute, 58 CAL. L. REV. 3, 4 (1970).

55 See Deborah J. Barrow \& Thomas G. WAlker, A Court Divided: The Fifth Circuit Court of APPEAls AND the POLITICS OF Judicial ReForm 1-10 (1988) (discussing Earl Warren's selection of judges to serve on a special ad hoc committee of the Judicial Conference when a proposal surfaced to split the Fifth Circuit and members of the Judicial Conference did not agree on a response).

${ }_{56}$ See Ulmer, supra note 9, at 11; see generally Wahlbeck, supra note 9.

57 See, e.g., Laura E. Little, Loyalty, Gratitutde, and the Federal Judiciary, 44 AM. U. L. REV. 699 (1995).

${ }^{58}$ For example, Earl Warren had presumed that his fellow Justices would-as he thought right-agree to disclose their finances, an obligation then being applied to lower court jurists. Several of the Justices balked at a mandatory regime, and the Chief Justice could not bind them. See 1969 Ann. ReP. OF THE DiRECTOR OF THE Admin. OfFice of THE U.S. COURTS, Reports of the Proceedings of the Judicial Conference of the United States 42-43 (June 10, 1969); Edward Ranzal, 52 U.S. Judges Balk at Curb on Activities, N.Y. TIMES, July 3, 1969, at 1 (stating that a majority of Justices rejected Chief Justice Warren's suggestion that the Supreme Court adopt these rules). The Ethics in Government Act now requires Justices to make such disclosures. See Pub. L. No. 95-521, 92 Stat. 1824, 1851, $1861 \S \S 301,308(9)$ (Oct. 26, 1978) (codified as amended at 5 U.S.C. app. $4 \S \S 101(11), 109(10))$. Chief Justice Rehnquist also met opposition from members of the Judicial Conference when he sought to limit state prisoners' use of habeas corpus. See Stephen L. Wasby, The Revolt of the Chief Judges, 37 CRIM. L. Bull. 445 (2001).

${ }^{59}$ U.S. CONST. art. I, $§ 3$, cl. 6.

${ }^{60}$ The Judiciary Act of 1789 , ch. $20, \S 1,1$ Stat. 73. Also noted is that the Chief Justice, and other Justices, had the power to certify writs of error. Id. $\S 25$. Congress also designated chief justices for territorial courts. See, e.g., 1 SEN. EXEC. J. 282 (June 26, 1798) (statement of President John Adams) (announcing the nomination of the Chief Justice of the Mississippi Territory); 9 SEN. ExEC. J. 340 (June 22, 1854) (state- 
Chief Justice of the Supreme Court of the United States" came into use. ${ }^{61}$ After the Civil War, when the victorious North wanted to impress a federal stamp upon the nation, another title, "Chief Justice of the Union,"

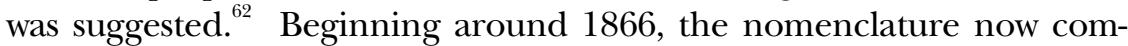
mon-Chief Justice of the United States-appeared in the text of federal statutes. $^{63}$

In 1888, Melville W. Fuller took the current title as part of his commission, as have Chief Justices thereafter. ${ }^{64}$ But in 1888, the title-Chief Justice of the United States — was inapt. Fuller did not have a range of ways to communicate to or affect the work of lower federal courts, nor did those judges have ready means of connecting to each other. ${ }^{65}$ The administrative needs of the federal judiciary were met in the early decades primarily by the Department of Treasury ${ }^{66}$ and then by the Department of the Interior ${ }^{67}$ before coming under the bailiwick of the Department of Justice, created in $1870 .^{68}$

Even as the twentieth century began, the hundred or so life-tenured federal judges, who were dispersed across the nation as they handled

ment of President Franklin Pierce) (announcing the nomination of the Chief Justice of the Territory of Nebraska); 18 SEN. EXEC. J. 154 (Jan. 23, 1868) (statement of President Andrew Johnson) (announcing the nominations of the Chief Justices of the Territory of Utah and the Territory of Arizona).

${ }^{61}$ Fish, Office of Chief Justice, supra note 3, at 9.

${ }^{62} I d$.

${ }^{63} I d$. at 10 (citing Act of July 23, 1866, 14 Stat. 205; Judiciary Act of April 10, 1869, ch. 22, 16 Stat. 44; Act of March 3, 1911, 36 Stat. 1089). The term "Chief Justice of the Supreme Court of the United States" was also used in some statutes. Id. (citing Act of June 17, 1910, 36 Stat. 469). Some attribute the change in nomenclature to the persistence of Chief Justice Salmon P. Chase, who reportedly insisted that Senators refer to him using that title when he presided at the impeachment hearings for President Andrew Johnson in 1869. See William A. Richardson, Chief Justice of the United States, or Chief Justice of the Supreme Court of the United States?, reprinted in 49 NEW ENG. HIST. \& GENEALOGICAL REG. 275, 277 (1895); see also CHARLES FAIRMAN, RECONSTRUCTION AND REunion, 1864-88, pt. 1, at 738 (The Oliver Wendell Holmes Devise History of the Supreme Court of the United States, vol. 6, Paul A. Freund ed., 1971).

${ }^{64}$ See Richardson, supra note 63, at 278.

${ }^{65}$ See Peter Graham Fish, The Politics of Federal Judicial Administration 89 (1973) (noting occasional correspondence).

${ }^{66}$ See Act of Sept. 2, 1789, 1 Stat. 65 (establishing the Department of Treasury with responsibility for disbursing all appropriated money from the Treasury and receiving all revenues, including funds for and from the federal courts).

${ }^{67}$ See Act of Mar. 3, 1849, § 4, 9 Stat. 395 (transferring court-related powers from the Department of Treasury to the Department of Interior, which was established by this act).

${ }^{68}$ See Act of June 22, 1870, $\S \S 1,2,15,18,16$ Stat. 162 (establishing the Department of Justice and the offices of Attorney General and Solicitor General, and transferring to the Department of Justice authority for the finances of the federal courts and the responsibility of publishing court opinions "deem[ed] valuable for preservation"). 
about thirty thousand cases a year, were mostly left to their own devices. They relied in large part on the procedural rules of the states in which they sat and they had few formal channels, outside of published opinions, through which to communicate with each other. As Chief Justice William Howard Taft complained in the early 1920s, each judge was left to "paddle[] his own canoe."

\section{A New Federal Bureaucracy}

Taft's leadership changed that isolation, as he helped bring into being the institutional presence of the federal judiciary; he launched a project that his successors, most notably Chief Justices Warren, Burger, and Rehnquist, elaborated. $^{70}$ Taft successfully pressed Congress to expand the number of jurists and to license judicial meetings to examine the business and needs of the judiciary. One dimension of these changes can be seen through the data provided in the table below, which outlines the number of judges and the duration of their service during three time periods. ${ }^{71}$

\footnotetext{
${ }^{69}$ William Howard Taft, Adequate Machinery for Judicial Business, Address Before the Judicial Section of the Am. Bar Ass'n, reprinted in 7 A.B.A. J. 453, 454 (1921).

${ }^{70}$ Even as Taft expanded the role, his duties as Chief Justice were "minimal" when compared to those of Burger. See STEAMER, supra note 17, at 13. For other discussions, see generally Fish, Office of Chief Justice, supra note 3; Post, supra note 11; Theodore W. Ruger, The Chief Justice's Special Authority and the Norms of Judicial Power, 154 U. PA. L. REV. 1551 (2006); Ruger, supra note 31.

${ }^{71}$ This table, jointly authored by Professor Resnik and Stephen Wu, Yale Law School, Class of 2005, reflects a series of decisions about how to count the length of service of jurists. Explanations and sources are provided in Resnik, Judicial Selection, supra note 1, at 648-58 chart 4 \& app. The underlying information comes from government databases on judges and their length of service. See Members of the Supreme Court of the United States, http://www.supremecourtus.gov/about/members.pdf (last visited Apr. 5, 2006); Biographical Directory of Federal Judges, Federal Judicial Center, http://www.fjc.gov/public/home.nsf/hisj; see generally Albert Yoon, Love's Labor's Lost? Judicial Tenure Among Federal Court Judges: 1945-2000, 91 CAL. L. REv. 1029 (2003).
} 
Table 1: Lengths of Service of Article III Judges: Contrasting Snapshots, 1800s/2000s

Federal Judges Whose Service Began Between 1789-1809

\begin{tabular}{lllll} 
Court & $\begin{array}{l}\text { \# of Judges } \\
\text { or Justices }\end{array}$ & $\begin{array}{l}\text { Avg. Length } \\
\text { of Service }\end{array}$ & $\begin{array}{l}\text { Avg. Age } \\
\text { at Start }\end{array}$ & $\begin{array}{l}\text { Avg. Age } \\
\text { at Death }\end{array}$ \\
\hline \hline Supreme & 16 & 14 years & 47 years & 67 years \\
\hline Lower & 47 & 16 years & 43 years & 64 years
\end{tabular}

Federal Judges Whose Service Terminated Between 1833-1853

\begin{tabular}{lllll} 
Court & $\begin{array}{l}\text { \# of Judges } \\
\text { or Justices }\end{array}$ & $\begin{array}{l}\text { Avg. Length } \\
\text { of Service }\end{array}$ & $\begin{array}{l}\text { Avg. Age } \\
\text { at Start }\end{array}$ & $\begin{array}{l}\text { Avg. Age } \\
\text { at Death }\end{array}$ \\
\hline \hline Supreme & 9 & 20 years & 49 years & 70 years \\
\hline Lower & 36 & 14 years & 47 years & 65 years
\end{tabular}

Federal Judges Whose Service Terminated Between 1983-2003

\begin{tabular}{lllll} 
Court & $\begin{array}{l}\text { \# of Judges } \\
\text { or Justices }\end{array}$ & $\begin{array}{l}\text { Avg. Length } \\
\text { of Service }\end{array}$ & $\begin{array}{l}\text { Avg. Age } \\
\text { at Start }\end{array}$ & $\begin{array}{l}\text { Avg. Age } \\
\text { at Death }\end{array}$ \\
\hline \hline Supreme & 6 & 24 years & 57 years & 88 years \\
\hline Lower & 530 & 24 years & 52 years & 75 years
\end{tabular}

Comparison of Lengths of Service: Lower Court Judges, 1800s/2000s

\begin{tabular}{lllll} 
Year Range & $\begin{array}{l}\text { \# of Judges } \\
\text { or Justices }\end{array}$ & $\begin{array}{l}\text { Avg. Length } \\
\text { of Service }\end{array}$ & $\begin{array}{l}\text { Avg. Age } \\
\text { at Start }\end{array}$ & $\begin{array}{l}\text { Avg. Age } \\
\text { at Death }\end{array}$ \\
\hline \hline $1789-1809$ & 47 & 16 years & 43 years & 64 years \\
\hline $1833-1853$ & 36 & 14 years & 47 years & 65 years \\
\hline $1983-2003$ & 530 & 24 years & 52 years & 75 years
\end{tabular}

As this table details, in the twenty years after the founding of the country, some sixteen people served for fourteen years as Justices; fortyseven lower court judges were on the bench for an average of sixteen years. Jumping forward almost two hundred years, the departure data provides one window into how much the ranks have swelled. Looking at roughly the last twenty years (between 1983 and 2003), 530 lower court judges left the bench after serving, on average, for twenty-four years. 
During that same interval, the six departing Supreme Court jurists similarly averaged about twenty-four years in that position. Chief Justice Rehnquist (who is not included in this data set because his service terminated in 2005) sat on the Court as either an Associate or Chief Justice for a total of thirty-three years. ${ }^{72}$

The growth in the number of judges is paralleled by the development of the federal judiciary's organizational shape. In 1922, Congress chartered the Conference of Senior Circuit Judges, ${ }^{73}$ and in 1939, it authorized the creation of an Administrative Office of the U.S. Courts (AO), which took over and revamped the tasks of budgeting and data collection, previously undertaken by the Department of Justice, and then developed new projects. ${ }^{74}$ With the 1948 reorganization of the parts of the U.S. Code dealing with the courts, the Conference of Senior Circuit Judges was renamed the Judicial Conference of the United States. ${ }^{75}$ In 1967, Congress chartered the Federal Judicial Center (FJC) $;^{76}$ the Chief Justice is the permanent chair of its Board. ${ }^{77}$ The FJC was charged with augmenting the research and teaching capacities of the judiciary. The FJC responds to research requests made by the Judicial Conference and its committees, launches its own projects, and conducts training sessions for judges—including "baby judges" school (the judiciary's two-week program for training new judges $)^{78}$ and special seminars.

In addition to chairing the FJC Board and having line authority over the Director of the AO, the Chief Justice presides at meetings of the Judicial Conference and is authorized by statute to submit reports of its

${ }^{72}$ See infra Appendix A, Tenure of Chief Justices of the United States, of Directors of the Administrative Office of the U.S. Courts, and of Directors of the Federal Judicial Center.

${ }^{73}$ See Act of Sept. 14, 1922, ch. 306, § 2, 42 Stat. 837, 838 (creating a conference of senior circuit judges "to advise [the Chief Justice] as to the needs of [each] circuit and ... the administration of justice in the courts of the United States").

${ }^{74}$ See Act of Aug. 7, 1939, ch. 501, 53 Stat. 1223 (codified as amended at 28 U.S.C. $\S \S 601-613(2000))$.

${ }^{75}$ Judicial Code of 1948, ch. 646, 62 Stat. 902 (June 25, 1948).

76 See Act of Dec. 20, 1967, Pub. L. No. 90-219, ch. 42, § 620, 81 Stat. 664 (codified as amended at 28 U.S.C. $\$ 621$ (2000)); see also Russell R. Wheeler, Empirical Research and the Politics of Judicial Administration: Creating the Federal Judicial Center, 51 L. \& CONTEMP. PROBS. 31 (1988); see generally ADMIN. OFFICE OF THE U.S. COURTS, THE FEDERAL COURT SYSTEM IN THE UNITED STATES: AN INTRODUCTION FOR JUDGES AND JUDICIAL AdMinistrators in OTHER COUNTRIES (2d ed. 2001) [hereinafter FEDERAL COURT SYSTEM].

${ }^{77} 28$ U.S.C. $\$ 621$ (2000). The Chief Justice also appoints three of the seven members of the Federal Judicial Center Foundation Board, which can accept funds to be used by the FJC. Id. $\S 629$.

78 "Baby Judges School” Jump Starts Learning Process, THIRD BRANCH, Aug. 2005, at 1. 
proceedings to Congress. ${ }^{79}$ Although specifically chartered by statute only to appoint the members of a standing committee on judicial discipline ${ }^{80}$ the Chief Justice (upon consultation with others) selects some two hundred fifty people who sit on the more than two dozen committees of the Judicial Conference. ${ }^{81}$ Those committees are staffed, in turn, by administrative personnel supervised by the Director of the $\mathrm{AO}$ and supported by FJC staff. The various administrative wings share headquarters in one of Washington's major buildings, named in the early 1990s after Justice Thurgood Marshall and located adjacent to Union Station. The day-to-day management of the entire judicial enterprise and its $\$ 5.4$ billion budget falls to the Director of the $\mathrm{AO} .{ }^{82}$

But it is the Chief Justice who today selects and has the power to remove the Director. ${ }^{83}$ Individual directors' tenures are, as is detailed in

7928 U.S.C. $\$ 331$ (2000).

${ }^{80}$ See id. ("If the Conference elects to establish a standing committee [on discipline], it shall be appointed by the Chief Justice ....").

${ }^{81}$ See Admin. Office of the U.S. Courts, JuRisdictional Statements: JURISDICTION OF COMMITTEES OF THE JUDICIAL CONFERENCE, http://www.uscourts.gov/ judconf_jurisdictions.htm (last visited May 7, 2006) [hereinafter COMMITTEES OF THE JUDICIAL CONFERENCE] (describing the committees of the Judicial Conference and their areas of responsibility). In 2004, the Judicial Conference, which had been relying on twenty-four committees, split the Facilities and Security Committee into two separate committees. See REPORT OF THE ProceEdings OF THE JUdicial CONFERENCE OF THE UNITED STATES 5 (Sept. 20, 2005), available at http://www.uscourts.gov/judconf/ sept05proc_final.pdf; see also Admin. Office of the U.S. Courts, Judicial Councils \& Conferences, http://www.uscourts.gov/understanding_courts/89914.htm (last visited Apr. 5, 2006) (listing the committees before the division of the Facilities and Security Committee).

${ }^{82}$ See 28 U.S.C. $\$ \S 601,602,604$ (2000) (creating the Administrative Office and vesting all of its functions and powers in the Director, including supervision of court administrative personnel, disbursal of funds, and collection of statistical data on the business of the courts for submission to the Judicial Conference, the Attorney General, and Congress).

${ }^{83}$ See id. $\$ 601$ (stating that the AO is to be "supervised by a Director and a Deputy Director appointed and subject to removal by the Chief Justice of the United States, after consulting with the Judicial Conference"). In practice, Chief Justices have long been central to the selection of the Director of the AO. Statutory authority to appoint the Director, however, resided with the Court as a whole until 1990. Federal Courts Study Committee Implementation Act of 1990, Pub. L. No. 101-650, § 307, 104 Stat. 5089, 5112 (Dec. 1, 1990) (amending 28 U.S.C. $§ 601$ to provide for appointment by the Chief Justice). As the House Report supporting the revision put it: "the Administrative Office... does not serve the Supreme Court per se, for which reason, vesting the Supreme Court with authority to appoint the Director of the Administrative Office is illogical," but the Chief Justice "works on a daily basis with the Director of the Administrative Office and has an obvious and substantial interest in naming a qualified person to fill this major judicial branch position." Federal Courts Study Committee Implementation Act of 1990, H.R. Rep. No. 101-734 (1990), reprinted in 1990 U.S.C.C.A.N. 6860, 6863-64. The 1990 legislation stemmed from a recommendation made by the Federal Courts Study Committee, an entity chartered by Congress in 1988 and which 
Appendix A, linked to those of the Chief Justices with whom they work. Most recently, for example, Leonidas Ralph Mecham, who was appointed in 1985 under Warren Burger and continued when William Rehnquist assumed that position in 1986, served as AO Director throughout Rehnquist's tenure and resigned shortly after the Chief Justice's death in 2005 . $^{84}$

Academics might respond to this description of the Chief Justice's responsibilities with a proverbial "so what." A catalogue of powers on paper does not necessarily correspond to changes with implications for democratic theory and constitutional interpretation. The details below will, we hope, make plain that what the infrastructure of "administrative" functions permits is a profoundly new set of opportunities for the Chief Justice to shape American law through methods less visible and accessible to law professors and the public than that of opinion writing. Given America's constitutional commitments not only to separation of powers but also to constrained and visible power, the Chief Justice's expanding jurisdiction is increasingly countercultural.

filed its report with Congress in 1990. See Federal Courts Study Act, Pub. L. No. 100702, 102 Stat. 4642, 4644 (Nov. 19, 1988); REPORT OF THE FEDERAL CourTS STUdY COMMITTEE 150 (1990).

${ }^{84}$ See Longtime AO Chief Mecham to Step Down, LEGAL Times, Dec. 19, 2005, at 3 (describing his retirement, at age 77 , after he had "reigned over the administrative side of the judicial branch with a strong, behind-the-scenes hand"). Other Chief Justices and directors also worked interdependently. See, e.g., Richard A. Chappell, Looking Back at Federal Probation, 66 FED. Probation 3, 5 (2002) (describing the creation of the AO in 1939 and discussing its first Director, Henry Chandler, who served under Chief Justice Hughes and who had a particular interest in the probation system; Chandler influenced Hughes' decision to create a Judicial Conference committee focused on performance standards for probation officers). Warren Olney III-described by one biographer as "perhaps Warren's closest personal acquaintance outside his family for the great bulk of Warren's public career"-served as Director for the majority of Warren's term as Chief Justice. G. EdWARD White, EARL WARREn: A PUblic Life 97-98 (1982); see also Wheeler, supra note 76, at 39 (noting that Olney was a "close associate" of Warren during Warren's tenure as Governor of California). Rowland Kirks, a friend of Warren Burger before his appointment, took on the job soon after Chief Justice Burger's tenure began in 1969 and remained in the position until Kirks died in 1977. See Jean Hailey, Rowland Kirks, Administrator of U.S. Courts, Dies, WASH. POST, Nov. 3, 1977, at C12. Director Kirks was succeeded by William Foley, who served until replaced by Ralph Meachan in 1985. See generally THE History OF THE AdMINISTRATIVE OfFice OF THE United States Courts: SiXty Years OF SERVICE to the United States JUdiciary (Cathy A. McCarthy \& Tara Treacy eds., 2000); infra Appendix A, Tenure of Chief Justices of the United States, of Directors of the Administrative Office of the U.S. Courts, and of Directors of the Federal Judicial Center. 


\section{Policymaking Through the Judicial Conference}

These various aspects of the administrative charter to the Chief Justice came into being through congressional responsiveness in the 1920s to the concerns of William Howard Taft. He made several proposals, including that a council of judges meet annually; ${ }^{85}$ as noted, Congress responded by creating the Conference of Senior Circuit Judges. ${ }^{86}$

Initially, the nine senior circuit judges were charged with advising the Chief Justice about the "needs of [their] circuit[s] and as to any matters in respect of which the administration of justice in the courts of the United States may be improved." ${ }^{, 87}$ Transcripts (stored in the National Archives) exist for about the first twenty years of the annual meetings. ${ }^{88}$ Discussion consisted of oral reports from the senior circuit judges, describing how the individual judges with whom they worked were (or were not) managing to stay abreast of the work, as well as whether to request more judgeships. As the decades advanced, topics ranged from better salaries, facilities, and supplies to concerns about rules of procedure, sentencing laws, and the need to provide indigent defendants with lawyers. $^{89}$

By mid-century, the Judicial Conference took on its current form. Chief Justice Earl Warren deserves credit for persuading the circuit judges to permit trial-level judges to join their ranks. ${ }^{90}$ Today, the Chief Justice presides over a Judicial Conference of twenty-seven members. ${ }^{91}$

${ }^{85}$ See Taft, supra note 69 , at 454 . Also proposed was reorganization of the judiciary and alteration of the jurisdiction of the Supreme Court to make most of it discretionary. See id.; William Howard Taft, Three Needed Steps of Progress, 8 A.B.A. J. 34 (1922); Hon. William Howard Taft, The Possible and Needed Reforms in the Administration of Justice in Federal Courts, 8 A.B.A. J. 601 (1922); see also Edward A. Hartnett, Questioning Certiorari: Some Reflections Seventy-Five Years After the Judges' Bill, 100 COLUM. L. REV. 1643, 1660-1704 (2000); Swindler, supra note 17, at 248.

${ }^{86}$ See Act of Sept. 14, 1922, ch. 306, § 2, 42 Stat. 837, 838; see also supra note 73 and accompanying text. In 1937, Congress added the chief judge of the United States Court of Appeals for the District of Columbia, and in 1948, the Conference of Senior Circuit Judges was renamed the Judicial Conference of the United States. See Act of June 25, 1948, ch. 646, 62 Stat. 902 (codified as amended at 28 U.S.C. $\$ 331$ (2000)).

${ }^{87}$ Act of Sept. 14, 1922, ch. 306, § 2, 42 Stat. 837, 838.

${ }^{88}$ See Judicial Conference Meetings Records, Record Group (RG) 116, National Archives, Washington D.C.; see also Resnik, Trial as Error, supra note 1, at 940 n.50 (describing how these materials are organized).

89 See Resnik, Trial as Error, supra note 1, at 955-58; Resnik, Constricting Remedies, supra note 17 , at $269-79$.

${ }^{90}$ District judges became a part of the Conference in 1957. Act of Aug. 28, 1957, Pub. L. No. 85-202, 71 Stat. 476 (codified at 28 U.S.C. $\$ 331$ (2000)).

${ }^{91} 28$ U.S.C. $\$ 331$ (authorizing the Chief Justice to call annual and special meetings and to preside at them, as well as to excuse attendance of individuals and to "summon" replacement judges). 
By statute, the chief judge of each federal circuit attends, as does the Chief Judge of the Court of International Trade. In addition, each circuit sends a district judge, who serves for a term of three to five years. ${ }^{92}$ The Conference now meets twice yearly and, aided by staff from the AO and the FJC, relies on an Executive Committee and more than two dozen standing committees appointed by the Chief Justice, some devoted to rulemaking and others addressing topics such as technology, criminal justice, and international judicial relations. ${ }^{93}$

In terms of the issues considered, in the early 1930s, the Conference was self-conscious about its own charter and concerned that its authorizing legislation did not permit it to consider a broad set of questions. The Conference sought legislative revision to expand its mandate, ${ }^{94}$ but Congress did not respond directly. ${ }^{95}$ Yet, over the decades, the Judicial Conference took on a wider set of concerns. ${ }^{96}$

92 Id.

${ }^{93}$ For example, the Committee on International Judicial Relations includes judges and a "liaison member from the State Department," and its "mission" includes coordinating "the federal judiciary's relationship with foreign judiciaries and other organizations interested in international judicial relations and the establishment and expansion of the rule of law." Preface to Federal COURT System, supra note 76. For the current committees of the Judicial Conference, see COMMITTEES OF THE JUDICIAL CONFERENCE, supra note 81.

${ }^{94}$ See Transcript at 335 (Oct. 3, 1930), in Judicial Conference Meetings Records, supra note 88, in Box 6 (Oct. 1929-Oct. 1930), Folder 1930 (Minutes and Transcript with index).

${ }^{95}$ The Conference asked a few times for authorization to make recommendations with regard to "changes in statutory law affecting the jurisdiction, practice, evidence and procedure." See, e.g., 1930 JUDICIAL CONFERENCE REPORT, reprinted in U.S. ATT'Y GEN. ANN. REP. FOR THE FISCAL YEAR 1930 6; 1931 JUDICIAL CONFERENCE REPORT, reprinted in U.S. ATT'Y GEN. ANN. REP. FOR THE FISCAL YEAR 1931 4, 12 (including the same request, to avoid "any question as to the scope of the authority which the Congress intended to confer upon the Conference"); 1932 JUDICIAL CONFERENCE REPORT, reprinted in U.S. ATT'Y GEN. ANN. REP. FOR THE FISCAL YEAR 1932 6, 12 (expressing intent to "renew its recommendation as to the advisability of this legislation"). Although not amending the provision creating the Conference, Congress did give the Supreme Court the power to make rules of "practice and procedure." See Rules Enabling Act of 1934, Pub. L. No. 73-415; 48 Stat. 1064 (codified as amended at 28 U.S.C. $\$ \$ 2071-2077$ (2000)). Revisions were made to the section dealing with the Conference in 1948, but they were intended to be stylistic rather than substantive. See Revision of Titles 18 and 28 of the United States Code: Hearings Before Subcomm. No. 1 of the H. Comm. on the Judiciary on H.R. 1600 E 2055, 80th Cong. 3 (1947) (statement of Rep. Edward J. Devitt) (commenting that the 1948 revisions to the U.S. Code did not alter the directive to the Conference). The 1948 revisions did include the provision that the Chief Justice should "submit to Congress an annual report of the proceedings of the Judicial Conference and its recommendations for legislation," explained by the Revisor's Notes as "authoriz[ing] the communications to Congress of information which now reaches that body only because [it is] incorporated in the annual report of the Attorney General." See Revisor's Notes, Legislative History of Title 28, United States Code, Judiciary and 
For example, during the tenure of Chief Justice Warren, the Conference took up what was then called "protracted" and is now termed large-scale or complex litigation. At the Conference's behest, Congress created the multidistrict litigation (MDL) panel, ${ }^{97}$ which determines whether to consolidate cases filed in different federal courts around the country and involving similar claims (such as those concerning injuries from airplane crashes or allegations of antitrust or securities violations). During the Warren era, the Judicial Conference also began to sponsor educational programs, aimed at teaching judges how to handle both protracted and more ordinary cases. Warren is also credited with having been instrumental in obtaining congressional support in the mid-1960s to create the FJC. ${ }^{98}$ Other areas of concern for Warren were bail reform, reconsideration of the bankruptcy system, and establishment of public defender organizations for criminal defendants in the federal courts. ${ }^{99}$ In addition, Warren guided discussions at the Judicial Conference that culminated in a recommendation to the American Law Institute that it study federal jurisdictional grants. ${ }^{100}$ The outcome was a 1969 ALI proposal to broaden federal question jurisdiction by dropping the amount in controversy requirement while narrowing diversity jurisdiction somewhat. ${ }^{101}$

By most accounts, however, the profound changes in agenda-setting occurred during the tenure of Warren Burger. Whatever the factors

Judicial Procedure at A1, A45 (Roy M. Mersky \& J. Myron Jacobstein eds., Gaunt \& Sons, U.S. Government Documents, 1971); see also Resnik, Constricting Remedies, supra note 17, at nn.304-06 and accompanying text.

${ }^{96}$ See Resnik, Trial as Error, supra note 1, at 957-96 (providing examples of positions taken by the Judicial Conference).

${ }^{97} 28$ U.S.C. $\$ 1407$ (2000). For the history of that innovation and a comparison of its development with that of class actions, see generally Judith Resnik, From "Cases" to "Litigation," 54 L. \& CONTEMP. PROBS. 5 (1991).

${ }_{98}$ See Resnik, Trial as Error, supra note 1, at 942-49; Swindler, supra note 17, at 25355; Earl Warren, Address to the American Law Institute, 40 A.L.I. PrOC. 25, 27 (1963); Wheeler, supra note 76 , at $38-41$.

${ }^{99}$ Warren, supra note 98 , at 30-32.

100 See 1956 JUdiCIAL CONFERENCE REPORT, reprinted in U.S. ATT'Y GEN. ANN. REP. FOR THE FISCAL YEAR 1956 at 15; Earl Warren, Address to the American Law Institute, 36 A.L.I. PROC. 27, 31-34 (1959).

${ }^{101}$ See ALI, STUdy OF THE Division Of JURISDiction BETWEen STATE AND FEDERAL COURTS 4 (federal question jurisdiction), 2-3 (diversity jurisdiction) (1969). One scholar has noted that in another context-a case study regarding proposed creation of a federal district court in San Diego-Warren served as a quiet participant and showed concern about what form of engagement was appropriate in light of his role. See Carl Baar, When Judges Lobby: Congress and Court Administration (Aug. 1969) (unpublished two-volume Ph.D. dissertation, University of Chicago), available for purchase at http://resources.library.yale.edu/online/viewrecorddetpublic.asp?whatcaseedit $=960$ (also on file with the Van Pelt Library, University of Pennsylvania). 
(different professional backgrounds, Congresses with whom they interacted, personal styles, political attitudes, judgments about the utilities of visible interventions or about judicial role, or jurisprudential philosophies) influencing Earl Warren's more circumspect stance, Chief Justice Burger took a different tack. As one commentator put it, within short order of assuming that position, Chief Justice Warren Burger had introduced a new type of activism into the role of Chief Justice: leader of law "reform" of both the federal and the state systems ${ }^{102}$ in a fashion "broader than anything in the nation's judicial experience."103 In 1974, Chief Justice Burger described his own first five years as full of "progress," evidenced by initiatives that included the creation of the Institute for Court Management to train administrators for state and federal courts, the establishment of Circuit Executive positions in the federal courts, the development of grievance procedures for prisoners, and the chartering of the National Center for State Courts to link state courts. ${ }^{104}$

Chief Justice Burger's administrative interests reflected his attitudes towards federalism and his skepticism about some of the Warren Court's constitutional reforms. ${ }^{105}$ Burger encouraged state courts to improve

${ }^{102}$ Swindler, supra note 17, at 241-42; see also id. at n.6 (citing a 1971 speech in which the Chief Justice stated that he had an "obligation to be concerned about the problems of state courts as well as the federal courts because the problems of justice are indivisible").

${ }^{103} I d$. at 264. "Activism" is the term used by others to capture Burger's efforts at court reform and his work as Chair of the Judicial Conference. See Arthur R. Landever, Chief Justice Burger and Extra-Case Activism, 20 J. PuB. L. 523, 523 (1971) ("The term 'activism' as used in this paper relates to the Chief Justice's myriad activities in judicial administration ...."); see also Tamm \& Reardon, supra note 17, at 452 (commenting on the degree to which Burger expanded the role of the Chief Justice); Comments of Jeffrey B. Morris, 1982 Virginia Conference, supra note 3, at 169 (characterizing Burger's tenure as a "watershed" in the federal judiciary's relations to state courts).

${ }^{104}$ Letter from Warren E. Burger to Chesterfield Smith, President of the American Bar Association (Aug. 8, 1974), reprinted in JUDICIAL ADMINISTRATION: TEXT AND READINGS 70-73 (Russell R. Wheeler \& Howard R. Whitcomb eds., 1977) [hereinafter JUDICIAL ADMINISTRATION]; see also Swindler, supra note 17, at 245 (describing the incorporation of the National Center for State Courts in 1971 as "traceable to the Chief Justice's affirmative proposals"); Tamm \& Reardon, supra note 17, at 454-92 (detailing initiatives to Congress on state-federal relations); STEAMER, supra note 17, at 188-92 (discussing those agendas). As Burger's Administrative Assistant, Mark Cannon, put it, "The very existence of the Institute for Court Management, the National Center for State Courts, the State-Federal Judicial Councils, the National Institute of Corrections, and others are due to him." 1982 Virginia Conference, supra note 3, at 170.

${ }^{105}$ Other commentators have also noted Burger's efforts to use his administrative position to advance his vision of the proper role of federal courts and the centrality of state court decisionmaking. See, e.g., Tamm \& Reardon, supra note 17, at 492-99. Further, in his jurisprudence as in his speeches, Chief Justice Burger argued that many decisions were "more properly left to the determination by the States and the people than to the courts operating under the broad mandate of the Fourteenth Amend- 
their own processes, ${ }^{106}$ in part as a means of enhancing advocates' abilities to argue to the Supreme Court that it, in turn, ought to constrain the reach of national powers in both civil and criminal contexts. ${ }^{107}$ Objecting to "added burdens" on the federal courts, ${ }^{108}$ Chief Justice Burger also sought to cut back on federal court jurisdiction-for example, by advancing proposals to abolish diversity jurisdiction ${ }^{109}$ and to limit prisoner litigation. ${ }^{110}$ Other techniques aimed at curbing use of courts,

ment." Gordon v. Lance, 403 U.S. 1, 6 (1971). The decision in Gordon reversed the West Virginia Supreme Court of Appeals, which had concluded that West Virginia's requirement that incurring public debt required a supermajority vote violated the Fourteenth Amendment. Justices Brennan and Marshall dissented, stating that the Supreme Court of West Virginia had correctly read the mandates of Baker v. Carr, 369 U.S. 186 (1962), and of Reynolds v. Sims, 377 U.S. 533 (1964), to require invalidation of the West Virginia system; the supermajority rule had, between 1964 and 1968, resulted in rejection of a series of efforts to increase public school funding through special bonds. Gordon, 403 U.S. at 8; Lance v. Bd. of Educ. of County of Roane, 170 S.E. 2d 783, 788-91 (W. Va. 1969).

${ }^{106}$ See Swindler, supra note 17, at 247 n.20 (citing a speech given by the Chief Justice before the National Association of Attorneys General on proposals for "self-help").

${ }^{107}$ See id.

${ }^{108}$ Warren E. Burger, Annual Report on the State of the Judiciary, Remarks of Warren E. Burger, Chief Justice of the United States, Before the American Bar Association Mid-Winter Meeting 1 (Feb. 23, 1975), reprinted in STATE OF THE FEDERAL JUdiCIARY: ANNUAL REPORTS OF THE Chief Justice OF THE Supreme COURT OF THE United STATES (Shelley L. Dowling ed., 2000) [hereinafter ANNUAL REPORTS OF THE CHIEF JusticE]; see also Warren E. Burger, Report on Problems of the Judiciary, Remarks of Warren E. Burger, Chief Justice of the United States, Before the American Bar Association 3 (Aug. 14, 1972), reprinted in ANNUAL REPORTS OF THE CHIEF JUSTICE (stating that additional federal judges are needed "not because anyone in the system wants this expansion," but because "there is no escape from constantly enlarging the federal judicial establishment except to adopt new judicial methods and improve performance ... and to have Congress carefully scrutinize all legislation that will create more cases").

${ }^{109}$ Warren E. Burger, Address to the American Law Institute (May 20-23, 1975), in 52 A.L.I. PROC. 29, 37-38 (1975) (stating that "something must be done" about the court's docket and recommending that Congress abolish diversity of citizenship, eliminate three-judge district courts, and remove all mandatory jurisdiction of the Supreme Court not constitutionally required).

${ }^{110}$ Burger was eager for prisons to develop grievance procedures to be used as a predicate to or in lieu of federal litigation. See Chief Justice Warren E. Burger, The Condition of the Judiciary, Year-End Report 5 (Jan. 3, 1976), reprinted in ANNUAL REPORTS OF THE CHIEF JUSTICE, supra note 108 (urging that "[f]ederal judges should not be dealing with prisoner complaints which, although important to a prisoner, are so minor that any well-run institution should be able to resolve them fairly without resort to federal judges"); see also Warren E. Burger, Report on the Federal Judicial Branch, Remarks of Warren E. Burger, Chief Justice of the United States to the American Bar Association 12 (Aug. 6, 1973), reprinted in ANNUAL REPORTS OF THE CHIEF JUSTICE, supra note 108 (recommending that Congress create "a statutory administrative procedure for federal prisons to provide for hearing prisoner complaints ... and require that these procedures be exhausted before any proceeding could be filed in federal courts"); Chief Justice Warren E. Burger, Year-End Report on the Judiciary 12-13 (Dec. 29, 1980), reprinted in ANNUAL 
promoted by Burger, were expanded reliance on alternative dispute resolution ${ }^{111}$ and on long-range planning. ${ }^{112}$

Commentators described Chief Justice Burger as using his authority over committee appointments as a means of advancing his agendas. Those chosen to serve on an Advisory Committee on the Criminal Rules were said to be more sympathetic to "a law enforcement perspective" than had been individuals selected under Chief Justice Warren ${ }^{113}$ (who might in turn have been characterized as more responsive to concerns about fair process for defendants). The appointments that Chief Justice Rehnquist made to committees have also been argued to be partisan. ${ }^{114}$ Further, as rule-making committees came in the 1960s and thereafter to serve as "continuing bodies," their powers grew, thereby enhancing the impact of the Chief Justice's ability to influence committees' composition and charters. ${ }^{115}$

REPORTS OF THE CHIEF JUSTICE, supra note 108 (discussing the need to improve prison conditions and for rehabilitation, as well as the utility of grievance procedures as a means of expediting the petition process and reducing the federal courts' caseload).

${ }^{111}$ See Warren E. Burger, Year-End Report on the Federal Judiciary 5 (Jan. 1, 1978), reprinted in ANNUAL REPORTS OF THE CHIEF JUSTICE, supra note 108 (reporting that the Judicial Conference, the Conference of Chief Justices, and the ABA sponsored a 1976 conference at which participants "probed at and challenged traditional assumptions of our justice system, particularly the view that litigation in the courts is the best means to resolve disputes"); Chief Warren E. Burger, Year-End Report 3 (Dec. 31, 1978), reprinted in ANNUAL REPORTS OF THE CHIEF JUSTICE, supra note 108 (describing an experimental arbitration program in three district courts and stating that the program provides "hope ... that many cases may be diverted away from the federal courts, with savings for all-in less time than in courts"); Chief Justice Warren E. Burger, Year-End Report on the Judiciary 3 (Dec. 31, 1979), reprinted in ANNUAL REPORTS OF THE CHIEF JUSTICE, supra note 108 (stating that the Federal Judicial Center, in cooperation with the Department of Justice, was evaluating the experimental programs in the district courts and that "[1] essons in the states suggest that court-annexed arbitration may reduce substantially the time and costs of resolving certain types of civil disputes"); Chief Justice Warren E. Burger, Year-End Report on the Judiciary 5 (Dec. 29, 1980), reprinted in ANNUAL REPORTS OF THE CHIEF JUSTICE, supra note 108 (stating that "[o]ften, minor disputes may be more effectively resolved, at less time and cost through informal channels rather than through extensive litigation in courts").

${ }^{112}$ See J. Clifford Wallace, The Future of the Judiciary: A Proposal, 27 CAL. W. L. REV. 361, 361-62 (1991) (describing Chief Justice Burger's request in 1980 that Judge Wallace help map a strategy for long-range planning).

113 See Carl Baar, Federal Judicial Administration: Political Strategies and Organizational Change, in JUDICIAL ADMINISTRATION, supra note 104, at 97, 109 n.25.

${ }^{114}$ See Jeffrey Stempel, Ulysses Tied to the Generic Whipping Post: The Continuing Odyssey of Discovery "Reform," 64 L. \& CONTEMP. PROBS. 197, 250-51 (2001) ("In short, under Chief Justice Rehnquist, the Committee process has been ideologized and politicized to the point where its credibility is subject to serious question.").

${ }^{115}$ Baar, supra note 113, at 106-07; see also id. at 109 n.28 (noting that "Chief Justice Burger has both criticized Supreme Court decisions on criminal procedure and sup- 
When Chief Justice Rehnquist came into office in 1986, his management approach was sufficiently distinct to prompt Linda Greenhouse to call Burger a "negative model" for Rehnquist. ${ }^{116}$ However much their styles varied, the agendas of Chief Justice Rehnquist forwarded much of what Chief Justice Burger had begun. To augment the judiciary's institutional resources devoted to planning, an "Office of Judicial Impact Assessment" came into being in 1991 inside the AO to focus on anticipating the effects of proposed legislation. ${ }^{117}$ That process proved complex and controversial. One issue was how to count the costs and the benefits of proposed new causes of action, new federal crimes, or of different remedies. Another was the challenge of estimating the number of claims that would be brought if a new law were to be enacted. ${ }^{118}$ In general, the focus has been on predicting whether and how much federal court dockets would change; projections of additional filings have generally been assumed to have negative consequences. ${ }^{119}$

In the early 1990s, under Chief Justice Rehnquist, the Judicial Conference created a committee on Long Range Planning; in 1995, it put forth the judiciary's first (and currently only) Long Range Plan, making

ported increased responsibilities for the Judicial Conference Advisory Committee on Criminal Rules") (citation omitted).

${ }^{116}$ Greenhouse, supra note 48, at 1367.

117 See Judith Resnik, The Programmatic Judiciary: Lobbying, Judging, and Invalidating the Violence Against Women Act, 74 S. CAL. L. REV. 269, 271 (2000); see also LONG-RANGE Planning for Circuit Councils: Speeches Presented at the MeEting of the JuDiCial Conference OF THE NinTH CirCuit (Fed. Jud. Ctr. 1992) (discussing the need to do so at a circuit level as well).

${ }^{118}$ The idea of assessing the "impact" of proposed legislation on courts was promoted by Chief Justice Burger in his 1970 State of the Judiciary Address and thereafter. See, e.g., Warren E. Burger, Remarks on the State of the Judiciary, Before the American Bar Association 18 (Aug. 10, 1970), reprinted in ANNUAL REPORTS OF THE CHIEF JUSTICE, supra note 108 (urging creation of a Judiciary Council to advise Congress, the President, and the Judicial Conference on matters affecting the federal courts and to report to Congress on the impact of any proposed legislation likely to enlarge federal jurisdiction); Warren E. Burger, Report on Problems of the Judiciary, Remarks of Warren E. Burger, Chief Justice of the United States, Before the American Bar Association 3 (Aug. 14, 1972), reprinted in ANNUAL REPORTS OF THE CHIEF JUSTICE, supra note 108 (suggesting that "every piece of legislation creating new cases be accompanied by a "court impact statement"”); Warren E. Burger, Annual Report on the State of the Judiciary, Remarks of Warren E. Burger, Chief Justice of the United States, Before the American Bar Association 11 (Feb. 23, 1975), reprinted in ANNUAL REPORTS OF THE CHIEF JUSTICE, supra note 108 (stating that because Congress undertook no "impact study" of the Speedy Trial Act, "we [referring to the Administrative Office] have undertaken to do so" and providing the results of that study); see also Tamm \& Reardon, supra note 17, at 474-75.

119 See generally CONFERENCE ON ASSESSING THE EFFECTS OF LEGISLATION ON THE Workload of The Courts: PAPERs ANd Proceedings (A. Fletcher Mangum ed., Fed. Jud. Ctr. 1995). 
ninety-three recommendations. ${ }^{120}$ Included was a request that Congress have a presumption against enacting any new rights for civil litigants, if those actions were to be enforced in federal court, as well as a presumption against prosecuting more crimes in federal courts. ${ }^{121}$ The Judicial Conference formally adopted that position as its policy, and the Conference also endorsed many other recommendations related to the allocation of power among state, federal, and administrative adjudicators and to the structure of decisionmaking and administration within the federal courts. $^{122}$

To summarize, under the leadership of the last three Chief Justices and with the support of the AO and the FJC, the Judicial Conference has enlarged its own purview in a variety of directions, and the Chief Justice's job has changed. In many respects, the judiciary's growth resembles that of other administrative agencies seeking to equip themselves to discharge assigned tasks. As concerns grew that demands of the cases filed exceeded the resources provided by Congress to decide them, the Federal Judicial Center developed and the Judicial Conference approved a "weighted case" system for the district courts to document why more slots were needed in particular courts. ${ }^{123}$ Further, when seeking resources for building courthouses or for staffing the Probation Department, paying public defenders, and keeping abreast of the workload, the judiciary has learned that it needs to provide data to a sometimes unin-

${ }^{120}$ See LONG RANGe Plan FOr the Federal Courts (Jud. Conf. of the U.S. 1995), 166 F.R.D. 49 (1995) [hereinafter LONG RANGE PLAN]. Congress had originally charged the Federal Courts Study Committee-a body that it created-with developing such a plan. See Federal Courts Study Act, supra note 83, § 102, 102 Stat. at 4644 (creating the Federal Courts Study Committee to "examine problems and issues currently facing the courts of the United States" and to "develop a long-range plan for the future of the Federal judiciary"). The congressionally-created committee encouraged the Judicial Conference to enhance its own long-range planning capability. See REPORT OF THE FEDERAL COURTS STUdy COMMITTEE, supra note 83, at 146.

${ }^{121}$ See LONG RANGe Plan, supra note 120, at 23, 166 F.R.D. at 83 (detailing Recommendation 1); $i d$. at 24-25, 166 F.R.D. at 84 (detailing Recommendation 2); $i d$. at 28-29, 166 F.R.D. at 88-89 (detailing Recommendation 6).

${ }^{122}$ The Conference formally adopted the ninety-three recommendations but did not specifically approve the commentary of the drafting committee. See Memorandum from L. Ralph Mecham, Secretary, Judicial Conf. of the United States, in LONG RANGE PLAN, supra note 120, at 1, 166 F.R.D. at 51.

${ }^{123}$ The Conference revised its case weighting system in 2004. See Admin. OfFicE OF THE U.S. COURTS, Caseload Highlights, in JUdICIAL BuSINESS OF THE U.S. COURTS 2223 (2004) [hereinafter 2004 JUDICIAL BUSINESS OF THE U.S. COURTS], available at http://www.uscourts.gov/judbus2004/front/caseload.pdf; PATRICIA LOMBARD \& CAROL KrafKa, 2003-2004 District COURT CASE-WEighting Study (Fed. Jud. Ctr. 2005), available at http://www.fjc.gov/public/home.nsf/pages/665. 
terested, unreceptive, or critical Congress. ${ }^{124}$ Under the leadership of several Chief Justices, the Judicial Conference and the AO have supported arguments for the judiciary with documentation in order to persuade Congress to provide resources.

But the parameters of the lobbying efforts on behalf of the judiciary and its leadership require further examination. While proposals for better facilities or more staff fall under the rubric of requests that would be made by any organization hoping to protect or to improve its own situation, other recommendations-such as taking stances against increasing the ranks of life-tenured judges, against more avenues to the federal courts through congressional enactment of specific new civil causes of action and federal crimes, or for transferring more responsibility from federal courts to administrative adjudicators-embody serious questions of constitutional law and of policy. While the Judicial Conference once categorized a range of matters as issues of "legislative policy" about which it should not comment, the Conference now regularly lets Congress know its views on an array of pending bills. The Chief Justice and the Conference have become important presences in the legislative process. ${ }^{125}$

Furthermore, the retrenchment in federal rights enforcement that marked the jurisprudence of both the Burger and Rehnquist chief justiceships can also be seen in the administrative agendas that they personally championed and that the Judicial Conference, under their leadership, often endorsed. ${ }^{126}$ Through a host of discretionary judgments,

124 See, e.g., Where the Money Goes: A Look At How The Judiciary's FY 2005 Budget Is Divided, THIRD BRANCH, Feb. 2005, at 1 (describing that about a quarter of the judiciary's budget supports courthouses, as the federal judiciary has to pay "rent" to the General Services Administration for the use of facilities). The federal judiciary has often used the term "crisis" to capture concerns about insufficient funds. See, e.g., Press Release, Leonidas R. Mecham, Director of the Administrative Office (Dec. 20, 2005) (announcing his retirement and stating that he would have retired earlier had the judiciary not been in "the midst of a debilitating financial crisis"); As Workload and Resources Head in Opposite Directions, Crisis Looms for Federal Courts, THIRD BRANCH, Mar. 2004, at 1. In 2006, Representative Sensenbrenner and Senator Specter, chairs of the House and Senate Judiciary Committees respectively, introduced new legislation to limit judicial rent to the actual costs of operating and maintaining judicial accommodations. See Judiciary Rent Reform Act of 2006, H.R. 4710, 109th Cong. (2006); A Bill To Provide Relief for the Federal Judiciary from Excessive Rent Charges, S. 2292, 109th Cong (2006).

${ }^{125}$ Resnik, Constricting Remedies, supra note 17, at 281-91; see also 2004 JUDICIAL BUSINESS OF THE U.S. COURTS, supra note 123, at 2 (reporting that "[a]t the direction of the Judicial Conference, the Administrative Office continued to pursue an active legislative agenda" in 2004).

${ }^{126}$ See also Carolyn Dineen King, Commentary, A Matter of Conscience, 28 Hous. L. REV. 955, 961-62 (1991) (discussing Chief Justice Rehnquist's advocacy of "congres- 
these Chief Justices have used their status as presiding officers to shape institutional decisions about what jurisdictional and remedial powers ought to reside in courts and agencies, both state and federal.

\section{Addressing the Nation}

In addition to guiding the Judicial Conference as it adopts formal policy through voting and influencing the work of the AO and FJC, the Chief Justice has an independent platform from which to speak. Chief Justice Taft and his successors went regularly to the American Bar Association and to the American Law Institute to give major addresses on their views of the judiciary's needs and priorities. ${ }^{127}$ Proposals to do more surfaced periodically, ${ }^{128}$ and, in the 1980s, Chief Justice Burger initiated another practice: providing annual "state of the judiciary" reports. While not quite the dramatic presentation to joint houses of Congress that some had suggested, ${ }^{129}$ the Chief Justice's annual statements, now customarily released on January 1, gain some attention in the national news as they recap one year and set out concerns for the next. ${ }^{130}$

Reading the statements of the different Chief Justices serving between the 1920s and today, certain issues-the size of dockets, the needs for regularization and rulemaking, and support of and funding for the judiciary-are regularly addressed. But under Warren Burger and William Rehnquist, another theme-curtailing the jurisdiction of the federal district courts-came into sharp relief. On several occasions, Burger opined against enlarging federal jurisdiction: "[T] he federal court system is for a limited purpose .... People speak glibly of putting all the problems of pollution, of crowded cities, of consumer class actions and

sional restraint in creating federal causes of action" and his concerns about keeping federal judgeships as prestigious positions, attractive to talented individuals).

${ }^{127}$ See FisH, supra note 65, at 50.

${ }^{128}$ See id. at 315-16 (describing Chief Justice Warren's support for a "State of the Judiciary" speech).

129 See E. Barrett Prettyman, Jr., The Chief Justice Should Address Congress, 56 A.B.A. J. 441, 441 (1970) (citing such a suggestion made in 1953 by William P. Rogers). Prettyman argued that the "new and frightening set of figures on the growth of litigation" warranted more attention, planning, and financing, and that public support could be generated through such national addresses that would pressure Congress to be more forthcoming in response to the judiciary's requests. Id. at 441, 444. According to Peter Fish, when Warren Burger proposed going to the Congress to deliver such addresses, the Nixon White House objected that such presentations could overshadow those of the President. See Fish, Office of Chief Justice, supra note 3, at 117. Fish also recounts that Judge Biggs had proposed that the Chief Justice address Congress. FISH, supra note 65, at 315-16.

${ }^{130}$ See Sofia Yakren, Chief Justices' Addresses to the ALI and the ABA, March 2, 2003 (memorandum on file with the authors). 
others in the federal courts." ${ }^{131}$ Chief Justice Burger objected to liberal standing doctrine, too "expansive" interpretations of federal statutes, too many prisoner petitions, and too narrow understandings of the immunity of government officials. ${ }^{132}$

While changing the format somewhat in terms of the style and timing of the yearly reports, William Rehnquist also used that medium to insist that too many issues were before the federal courts. ${ }^{133}$ For example, in one address, he cited as problematic new civil causes of action, such as the Child Support Recovery Act of 1992 (nicknamed the "Deadbeat Dad Act" and aimed at using federal courts to enforce support obligations of out-of-state parents). ${ }^{134}$ In another year-end report, he opposed the creation of new federal crimes, "such as those involving juveniles and handgun murders." ${ }^{135}$ Chief Justice Rehnquist also identified whole sets of cases, such as those filed under the Federal Employee Liability Act (FELA) and the Jones Act, as candidates for Congress to remove from the federal docket. ${ }^{136}$

${ }^{131}$ Warren E. Burger, Remarks on the State of the Judiciary, Before the American Bar Association 17 (Aug. 10, 1970), reprinted in ANNUAL REPORTS OF THE CHIEF JUSTICE, supra note 108; see also Warren E. Burger, Address to the American Law Institute, 49 A.L.I. PROC. 23, 29 (1972) ("Our basic system of justice, of course, lies within state power and it should remain that way, with Federal Courts functioning, as the Constitution intended they should, as courts of special and limited jurisdiction.").

${ }^{132}$ Warren E. Burger, Address to the American Law Institute, 57 A.L.I. Proc. 29, 33-34 (1980); see also id. at 32-33 (attributing the "litigation explosion" in part to federal courts' "expansive, rather than restricted" interpretation of new statutes providing federal causes of actions "along with a narrowing of the scope of immunity of government officials"); Warren E. Burger, Report on the Federal Judicial Branch, Remarks of Warren E. Burger, Chief Justice of the United States, to the American Bar Association 12-13 (Aug. 6, 1973), reprinted in ANNUAL REPORTS OF THE CHIEF JUSTICE, supra note 108 (suggesting that prisoners' claims be resolved by informal grievance procedures or administrative hearings, and that habeas cases be referred to "magistrates" or to special masters).

${ }^{133}$ See infra notes 158-59 and accompanying text; see also William H. Rehnquist, The 1997 Year-End Report on the Federal Judiciary 6 (Jan. 1, 1998), reprinted in ANNUAL REPORTS OF THE CHIEF JUSTICE, supra note 108 (stating that "the Effective Death Penalty Act and the [Prison Litigation Reform Act] appear to be promising examples of how Congress can reduce the disparity between resources and workload in the federal judiciary without endangering its distinctive character").

${ }^{134}$ See William H. Rehnquist, Address to the American Law Institute, 75 A.L.I. Proc. 55,58 (1998) (stating that "one senses [about this and other bills] from the context in which they were enacted that the question of whether the states are doing an adequate job in this particular area was never seriously asked"); Child Support Recovery Act of 1992, Pub. L. No. 102-521, 106 Stat. 3403 (Oct. 25, 1992) (codified as amended at 18 U.S.C. $§ 228$ ).

${ }_{135}$ William H. Rehnquist, 1993 Year-End Report on the Federal Judiciary 5 (1993), reprinted in ANNUAL REPORTS OF THE CHIEF JUSTICE, supra note 108.

${ }^{136}$ See Chief Justice William H. Rehnquist, 1991 Year-End Report on the Federal Judiciary, THIRD BRANCH, Jan. 1992, at 3 (citing a recommendation from the Federal Courts Study Committee, described, supra notes 83 and 120). 
Interested in limiting the role of courts, both Chief Justices Burger and Rehnquist also encouraged reliance on alternative dispute resolution. ${ }^{137}$ Their commitment to such alternatives can be seen in their public speeches and in the jurisprudence of the Court. During the chief justiceships of both Burger and Rehnquist, the Court moved away from the case law of earlier decades that had refused to enforce contracts requiring arbitration in lieu of pursuing federal statutory claims in court. ${ }^{138}$ In the 1980s and thereafter, plaintiffs who had signed contracts to arbitrate were sent to privately run dispute resolution programs to present their claims under federal securities, Truth-in-Lending laws, or state antidiscrimination statutes; the Court concluded that, as long as such resolution programs provided a sufficient method to vindicate such rights, contracts that precluded litigation were enforceable. ${ }^{139}$

${ }^{137}$ See supra note 111 (providing examples of Chief Justice Burger's admiration for alternative dispute resolution programs); William H. Rehnquist, 1986 Year-End Statement 5 (1986), reprinted in ANNUAL REPORTS OF THE CHIEF JUSTICE, supra note 108.

${ }^{138}$ See, e.g., Wilko v. Swan, 346 U.S. 427, 438 (1953) (declining to enforce the parties' arbitration clause when a plaintiff's claim was based on section 12(2) of the Securities Act of 1933 and discussing arbitration as too flexible and unregulated to serve as a substitute for adjudication), overruled by Rodriguez de Quijas v. Shearson/American Express, Inc., 490 U.S. 477, 485 (1989) (reinterpreting the Securities Act to permit enforcement of predispute arbitration agreements, lauding arbitration for its flexibility and informality, and noting that adjudication and arbitration both were forms of dispute resolution).

${ }^{139}$ During Burger's tenure, the Court initiated this line of cases when it decided Mitsubishi Motors Corp. v. Soler Chrysler-Plymouth, Inc., 473 U.S. 614 (1985). As the Court there explained its view: "By agreeing to arbitrate a statutory claim, a party does not forgo the substantive rights afforded by the statute; it only submits to their resolution in an arbitral, rather than a judicial, forum." $I d$. at 628. The Court later relied on Mitsubishi to hold in Gilmer v. Interstate/Johnson Lane Corp., 500 U.S. 20, 35 (1991), that an arbitration clause contained in an application to register as a securities representative with the New York Stock Exchange barred federal court review of a statutory age discrimination claim so long as the alternative forum provided an adequate means to vindicate statutory rights. More recently, in Green Tree Financial Corp. v. Bazzle, 539 U.S. 444, 453 (2003), the Court relied on these earlier precedents to hold that an arbitrator rather than a federal court must decide whether an arbitration clause contained in a standard loan agreement required arbitration of a class dispute. See also Buckeye Check Cashing, Inc. v. Cardegna, 126 S. Ct. 1204 (2006) (reversing the Florida Supreme Court's ruling that an arbitration clause could not be severed from an allegedly unlawful contract, and holding that the question of the contract's validity must be sent to arbitration). Further, although some lower courts had carved out a view that claims of discrimination in employment ought to be differently handled, the Court disagreed in Circuit City Stores v. Adams, 532 U.S. 105 (2001). For further discussion, see generally Paul D. Carrington \& Paul H. Haagen, Contract and Jurisdiction, 1996 SUP. CT. REV. 331 (1996); Judith Resnik, The Rights of Remedies: Collective Accountings For and Ensuring Against the Harms of Sexual Harrassment, in Directions in SEXual Harrassment Law 247-71 (Catharine MacKinnon \& Reva B. Siegel eds., 2004). 
During the last few years of his tenure, Chief Justice Rehnquist also regularly addressed the values of judicial independence. He criticized Congress and the Executive for engaging in behavior that, he believed, suggested that the coordinate branches of government did not sufficiently appreciate what an independent judiciary brings to a thriving democracy. ${ }^{140}$ In his last such annual report in 2004, Chief Justice Rehnquist objected specifically to attacks against individual judges' rulings but noted that the President could, through selection, seek to appoint judges more congenial to his point of view. ${ }^{141}$ On January 1, 2006, Chief Justice Roberts carried on the "30-year-old tradition," with a short statement focused mostly on the need for better funding for the judiciary and better salaries for judges. ${ }^{142}$

\section{Lobbying the Congress}

In the literature on judicial lobbying, Burger is infamous-with many commentators citing in particular his impact on the design of the bankruptcy system. When considering what came to be known as the 1978 reforms, members of Congress contemplated creating life-tenured judgeships for bankruptcy judges. ${ }^{143}$ The Judicial Conference took a position against that proposition, and the Chief Justice was a very present lobbyist opposed to conferring Article III status on bankruptcy judges. ${ }^{144}$

${ }^{140}$ See, e.g., Chief Justice William H. Rehnquist, 2004 Year-End Report on the Federal Judiciary, THIRD BRANCH, Jan. 2005, at 1 [hereinafter Rehnquist, 2004 Year-End Report] (discussing the "crisis" in funding and the attacks on the judiciary); see also Chief Justice William H. Rehnquist, Key Note Address, 46 AM. U. L. REv. 263, 267, 271-74 (1996) (discussing the value of judicial independence and appropriate and inappropriate ways to criticize and to influence the courts).

${ }^{141}$ See Rehnquist, 2004 Year-End Report, supra note 140, at 2-3 (stating that "public reaction to judicial decisions, if it is sustained and widespread, can be a factor in the electoral process and lead to the appointment of judges who might decide cases differently" but arguing that "Congress's authority to impeach and remove judges should not extend to decisions from the bench"); see also Russell R. Wheeler, Chief Justice Rehnquist as Third Branch Leader, 89 JUDICATURE 116, 118-19 (2005) [hereinafter Wheeler, Chief Justice Rehnquist] (discussing Chief Justice Rehnquist's comments on judicial independence and attacks on the judiciary).

${ }^{142}$ Chief Justice John G. Roberts, 2005 Year-End Report on the Federal Judiciary, THIRD BRANCH, Jan. 2006, at 1.

${ }^{143}$ See H.R. REP. NO. 95-595, at 7 (1977) (discussing House Bill No. 8200 and explaining that bankruptcy judges would become Article III judges, appointed by the President upon the consent of the Senate to life terms).

${ }^{144}$ See Vern Countryman, Scrambling to Define Bankruptcy Jurisdiction: The Chief Justice, the Judicial Conference, and the Legislative Process, 22 HARV. J. ON LEGIS. 1, 7-12 (1985). 
Although Burger's personal efforts at persuasion annoyed some members of the Senate, ${ }^{145}$ the legislation enacted bore signs of his impact. Instead of Article III status, Congress authorized bankruptcy judges to serve for fourteen-year terms. ${ }^{146}$ Yet these jurists also had jurisdictional authority over both "core" and "related" bankruptcy matters. ${ }^{147}$ In 1982, a plurality of the Supreme Court, not including Chief Justice Burger, concluded that this broad a grant of jurisdiction exceeded the constitutional limits of delegation to jurists lacking Article III tenure and salary protections. ${ }^{148}$ Chief Justice Burger's dissent, in turn, insisted that Congress need not respond by undertaking "a radical restructuring of the present system of bankruptcy adjudication."

The Court stayed its mandate to enable Congress to revise the bankruptcy system, ${ }^{150}$ but new legislation was not immediately forthcoming. ${ }^{151}$ In the interim, the $\mathrm{AO}$, at the request of the Judicial Conference, implemented an "emergency rule" under which district courts delegated bankruptcy matters to the bankruptcy judges in a manner understood to be constitutional. ${ }^{152}$ Chief Justice Burger used the opportunities of his 1982 and 1983 year-end reports to praise the effectiveness of the interim measures and to inveigh against granting bankruptcy judges Article III

${ }^{145}$ See Eric A. Posner, The Political Economy of the Bankruptcy Reform Act of 1978, 96 Mich. L. REv. 47, 90 (1997) (quoting Senator Dennis DeConcini describing Burger as having "not only lobbied, but pressured and attempted to be intimidating"); Nancy L. Ross, Carter Expected to Sign Revised Bankruptcy Bill, WASH. POST, Oct. 10, 1978, at D8 (noting that " $[\mathrm{s}]$ everal legislators accused the Chief Justice of breaching the doctrine of separation of powers").

${ }_{146}$ See Bankruptcy Reform Act of 1978, Pub. L. No. 95-598, § 201 (a), 92 Stat. 2549, 2657-58 (1978). The statute authorized bankruptcy judges to continue service beyond the 14-year term until such time as a successor was appointed and took office. Id.

${ }^{147}$ See id. $\$ 241(\mathrm{a}), 92$ Stat. at 2668-69.

148 See N. Pipeline Constr. Co. v. Marathon Pipe Line Co., 458 U.S. 50 (1982) (plurality opinion) (Brennan, J. joined by Marshall, J., Blackmun, J., and Stevens, J.); id. at 89-92 (Rehnquist, J., concurring, joined by O'Connor, J.); id. at 92 (Burger, C.J., dissenting); $i d$. at 92-118 (White, J., dissenting, joined by Burger, C.J., and Powell, J.). The exact parameters of the unconstitutionality have since been a source of debate. See generally Richard H. Fallon, Jr., Of Legislative Courts, Administrative Agencies, and Article III, 101 HARV. L. REV. 915 (1988); Judith Resnik, The Mythic Meaning of Article III Courts, 56 U. COLO. L. REV. 581 (1985).

${ }^{149}$ N. Pipeline, 458 U.S. at 92 (Burger, C.J., dissenting).

${ }^{150} I d$. at 88 (staying judgment until October 4, 1982); N. Pipeline Constr. Co. v. Marathon Pipe Line Co., 459 U.S. 813 (1982) (granting the Solicitor General's motion to stay the judgment until December 24, 1982).

${ }^{151}$ N. Pipeline Constr. Co. v. Marathon Pipe Line Co., 459 U.S. 1094 (1982) (declining, on December 23, 1982, the Solicitor General's motion to extend the stay).

${ }^{152}$ See Admin. OfFice of The U.S. Courts, Proceedings of the Judicial ConFERENCE OF THE UNITED STATES 91 (1982) (directing the Administrative Office to implement an emergency rule). 
status. ${ }^{153}$ The federal judiciary did not, according to the Chief Justice, support "casually resorting to creation of specialized [Article III] courts." ${ }^{\prime 154}$ In 1984, Congress passed a revised version of the statute that narrowed the jurisdictional grant somewhat and did not give life tenure to bankruptcy judges. ${ }^{155}$

Chief Justice Rehnquist pursued a similarly focused campaign, when he opposed aspects of the Violence Against Women Act (VAWA), legislation that was first introduced in 1990 and enacted in 1994. This multi-faceted statute had provisions for new federal criminal jurisdiction, funding for programs to protect victims of violence (with special attention paid to college campuses), enforcement of interstate protection orders, and a new civil rights damage remedy in federal court for victims of violence motivated by gender. ${ }^{156}$ It was the proposed new cause of action-permitting private damage actions in federal district court-that drew the Chief Justice's ire. After an initial draft was introduced in the early 1990s, the Judicial Conference chartered an Ad Hoc Committee on Gender-Based Violence, appointed by Chief Justice Rehnquist, to review the pending statute.

${ }^{153}$ See Warren E. Burger, 1983 Year-End Report on the Judiciary 5 (1983), reprinted in ANNUAL REPORTS OF THE CHIEF JUSTICE, supra note 108 (explaining that "due to congressional inaction following [Northern Pipeline], bankruptcy cases ha[d] been heard under a model interim bankruptcy rule recommended by the Judicial Conference of the United States" and that given the effectiveness of this rule, "[n]o extravagant, longrange expansion of the bankruptcy system is justified, and there is no need whatever to create 300 or more Article III 'lifetime judgeships' to deal with a passing problem”).

${ }^{154}$ Warren E. Burger, 1982 Year-End Report on the Judiciary 2-3 (1982), reprinted in ANNUAL REPORTS OF THE CHIEF JUSTICE, supra note 108; see also id. at 3 (stating that creation of "specialized Article III courts" would be "a remedy worse than the "disease'”).

${ }^{155}$ See Bankruptcy Amendments and Federal Judgeship Act of 1984, Pub. L. No. 98-353, § 104, 98 Stat. 333, 336 (codified at 28 U.S.C. $§ 152(a)(1)$ (2000)). More conflict between the Courts and Congress followed. In addition to setting bankruptcy judges' terms and defining their jurisdiction, the 1984 Act retroactively extended the terms of the bankruptcy judges then in office. William Foley, Director of the AO, thought that provision of questionable constitutionality and refused to authorize the pay for judges sitting with extended terms. Bankruptcy judges and commentators criticized Foley's action, and Director Foley eventually relented. See Bankruptcy Judge Debate, N.Y. TimeS, July 19, 1984, at D18; Stuart Taylor, Jr., Burger Said To Support Ban on Bankruptcy Pay, N.Y. Times, July 14, 1984, at A35; Stuart Taylor, Jr., U.S. Official Won't Pay Bankruptcy Judges, N.Y. Times, July 13, 1984, at D1.

${ }^{156}$ See Violence Against Women Act of 1994, Pub. L. No. 103-322, §§ 40001-40304, 108 Stat. 1796, 1902-42 (codified in scattered sections of 8, 18, and 42 U.S.C.) [hereinafter VAWA]. 
The Ad Hoc Committee's recommendation of opposition ${ }^{157}$ became official federal judicial policy. ${ }^{158}$ The Chief Justice explained that position in his 1991 year-end report, stating that the "broad definition of criminal conduct is so open-ended, and the new private right of action so sweeping, that the legislation would involve the federal courts in a whole host of domestic relations disputes." ${ }^{\text {"159 }}$ Relying on claims that a flood of lawsuits (tens of thousands, with costs estimated to range from "\$44 million dollars and 450 work years" to "\$81 million dollars and 922 work years" ${ }^{\$ 160}$ ) would follow if women had federal remedies for genderbased violence, the Judicial Conference reported to Congress that it did not support enactment of the new civil rights remedy of VAWA.

After the draft legislation was modified in response to the concerns raised by both state and federal judges and its scope narrowed, the Judicial Conference took no position on the propriety of enacting the civil rights remedy and supported aspects of the legislation related to education on fair treatment in courts. ${ }^{161}$ In 1994, with the support of attorneys general from some forty jurisdictions and many others, VAWA came into being. That version of the legislation included the provision of new federal jurisdiction (supplemental to that available in state courts) giving civil remedies to victims of gender-motivated violence. ${ }^{162}$

${ }^{157}$ Report of the Judicial Conference Ad Hoc Committee on Gender-Based Violence 1, 7 (1991).

${ }^{158}$ See Chief Justice William H. Rehnquist, Chief Justice's 1991 Year-End Report on the Federal Judiciary, THIRD BRANCH, Jan. 1991, at 1 (objecting that the proposed private right of action was too "sweeping").

${ }^{159} I d$. at 3 .

${ }^{160}$ A first estimate in 1991 put the annual cost to the judiciary as $\$ 62.5$ million and 691 work years; a second, in January of 1992, suggested " \$44 million and 450 work years," and a third, in June of 1992, offered an estimate of $\$ 81$ million and 922 work years. See Violence Against Women: Victims of the System: Hearing on S. 15 Before the Senate Comm. on the Judiciary, 102d Cong. 10 (1991) (quoting an Office of Judicial Impact Assessment estimate); Office of Judicial Impact Assessment, Admin. Office of the U.S. Courts, Judicial Impact Statement: Violence Against Women Act of 1991, S. 15 as Reported 2 (Jan. 8, 1992); Office of Judicial Impact Assessment, Admin. Office of the U.S. Courts, Judicial Impact Statement: Violence Against Women Act of 1991, S. 15 as Reported 1 (June 8, 1992).

${ }^{161}$ See Admin. Office of the U.S. Courts, Reports of the Proceedings of the JUDiCIAL CONFERENCE OF THE UNITED STATES 28 (1993) (“[T] he Conference takes no position on specific provisions of the proposed Violence Against Women Act ....").

${ }^{162}$ See VAWA, Pub. L. No. 103-322, § 40302(c), 108 Stat. 1796, 1941, which provided:

A person (including a person who acts under color of any statute, ordinance, regulation, custom, or usage of any State) who commits a crime of violence motivated by gender and thus deprives another of the right declared in subsection (b) shall be liable to the party injured, in an action for the recovery of 
Thereafter, the Chief Justice continued his criticism of VAWA. In 1998, in a speech before the American Law Institute, Chief Justice Rehnquist cited the civil rights remedy of VAWA (as well as other statutes) as an inappropriate expansion of federal jurisdiction. In his view, "traditional principles of federalism that have guided this country throughout its existence" should have relegated these issues to state courts. ${ }^{163}$ In 2000, in United States $v$. Morrison, the Chief Justice wrote the majority opinion that ruled, five to four, that Congress lacked the power under either the Commerce Clause or the Fourteenth Amendment to create the civil rights remedy of VAWA. ${ }^{164}$

And, as discussed above, Chief Justice Rehnquist's dislike of the expansion of federal remedies was not limited to his administrative and adjudicative opposition to VAWA. More generally, he guided the Judicial Conference, and he selected colleagues to lead the Conference's long-range planning that developed policies discouraging Congress from the creation of new federal rights. ${ }^{165}$ Constitutional scholars often speak of the "Rehnquist Court" but ought instead call his era the "Rehnquist Judiciary" to capture his effectiveness, of which doctrinal developments in the Court were only one aspect.

\section{Appointing Judges to Special Courts and Committees}

Yet another aspect of the powers held by the Chief Justice is important: the authority to select sitting jurists to serve on specialized courts and on committees. In the federal system, Congress has created a series of courts staffed by life-tenured judges already commissioned and temporarily assigned an extra obligation. Rather than using a system that mixes elements of randomness with purposive sampling (for example, drawing one name by lot from judges grouped by circuits), Congress has endowed the Chief Justice with the power to pick individual judges to sit on particular tribunals.

compensatory and punitive damages, injunctive and declaratory relief, and such other relief as a court may deem appropriate.

${ }^{163}$ See Chief Justice William H. Rehnquist, Remarks at Monday Afternoon Session, May 11-14, 1998, in A.L.I., 75TH ANNUAL MEETING: REMARKS AND ADDRESSES, at 57, 58 (1998) (citing bills on juvenile crime, the Anti-Car Theft Act of 1992, the Freedom of Access to Clinic Entrances Act of 1994, and the Child Support Recovery Act of 1992, in addition to VAWA). According to press reports, the Chief Justice also decided that the AO should not resist budget cuts aimed at cutting off funds for gender and race bias task forces. See Bruce D. Brown, Judiciary Won't Fight for Court Bias Studies, AM. LAWYER, Nov. 13, 1995, at 1 .

${ }^{164}$ United States v. Morrison, 529 U.S. 598, 627 (2000).

${ }^{165}$ See supra notes 120-22 and accompanying text (discussing the LONG RANGE PLAN); see also King, supra note 126, at 961. 
Specifically, the Chief Justice appoints the seven judges on the Judicial Panel on Multidistrict Litigation, ${ }^{166}$ the body created in the 1960s at the behest of the Judicial Conference to decide whether to consolidate cases pending around the country and to centralize pretrial decisionmaking in a judge designated by that panel. The Chief Justice also chooses the eleven judges who sit for seven-year terms on the Foreign Intelligence Surveillance Act (FISA) court $^{167}$ (now frequently in the news), which, since 1979, is reported to have approved more than 18,000 government requests for surveillance warrants. ${ }^{168}$ Furthermore, the Chief Justice selects the three judges comprising the appellate body empowered to review FISA Court denials of government requests-an activity that reportedly rarely occurs. ${ }^{169}$ The Chief Justice holds the power to select the five judges who constitute the Alien Terrorist Removal Court, chartered in 1996 to respond if and when the Department of Justice files cases seeking to deport legal aliens suspected of aiding terrorists. ${ }^{170}$ Until recently, the Chief Justice also designated the three members of the special division of the D.C. Circuit charged with appointing independent counsels. ${ }^{171}$ As a result of these various statutes, according to Professor

${ }^{166}$ See 28 U.S.C. $\$ 1407$ (d) (2000).

${ }^{167}$ See 50 U.S.C. $\$ 1803(\mathrm{a})$,(d) (2004); see also 50 U.S.C. $\$ 1842(\mathrm{~b})(2)$ (2000 \& Supp. I 2001) (authorizing the appointment by the Chief Justice of Magistrate Judges to hear applications to install wiretaps); id. § 1862(b) (1)(B) (2000 \& Supp. I 2001) (authorizing the Chief Justice to appoint a magistrate judge to hear applications for subpoenas).

${ }^{168}$ See FISA Annual Reports to Congress, available at http://www.fas.org/irp/ agency/doj/fisa/\#rept (follow "FISA Annual Reports to Congress" hyperlink; then follow hyperlink for desired year) (last visited May 7, 2006). For discussion of the FISA Court and the Chief Justice's appointment power more generally, see Ruger, The Judicial Appointment Power of the Chief Justice, supra note 31, at 365-67.

${ }^{169}$ See FISA Annual Reports to Congress, supra note 168; see also In re Sealed Case, 310 F.3d 717 (Foreign Int. Surv. Ct. Rev. 2002) (holding that neither FISA nor the Fourth Amendment barred the government from procuring a FISA warrant for the primary purpose of prosecuting a foreign agent where foreign intelligence gathering was also a significant purpose).

${ }^{170}$ See Antiterrorism and Effective Death Penalty Act of 1996, Pub. L. No. 104-132, 110 Stat. 1214 (codified in scattered sections of 8, 18, 28, 42 U.S.C.). The provision for appointment is 8 U.S.C. $§ 1532$.

${ }^{171}$ See 28 U.S.C. $\$ 49$ (d) (1994). Although the statute authorizing the Chief Justice to appoint members to the special division has not been repealed, the provision of the Independent Counsel Reauthorization Act of 1994 authorizing the division to appoint special counsels expired in 1999. See 28 U.S.C. $§ 599$. The division remains in existence only to monitor ongoing investigations and to dispose of petitions for attorneys' fees in concluded investigations. See id.; see also U.S. Court of Appeals for the District of Columbia, Division for the Purpose of Appointing Independent Counsels, http://www.cadc.uscourts.gov/internet/internet.nsf/content/Independent+Counsel (describing the current activities of the special division). As Professor Ruger has noted, commentators criticized Chief Justice Rehnquist's appointment of Judge David 
Theodore Ruger, Chief Justice Rehnquist made "over fifty such special court appointments," a total that Ruger noted was greater than the number of judicial appointments made during the first several decades of the United States. ${ }^{172}$

That this appointment authority is an important power can be seen from opposition to the idea of the Chief Justice wielding it. In the first decades of the twentieth century, Taft (both before and after he became Chief Justice) sought to detach the appointment of judges from a position on a particular court. Taft argued that Congress ought to depart from its practice (which persists today) of making line-by-line authorizations of individual judgeships designated for a specific district or circuit court. Instead, Taft wanted Congress to commission eighteen "judges-atlarge" to be dispatched at the discretion of the Chief Justice. ${ }^{173}$ Given that the lower federal courts had, in 1914, about 126 judges, ${ }^{174}$ the Taft proposal would have both increased the ranks of the judiciary by fourteen percent and helped to produce a cohort more affiliated with the national system than a particular locality.

Upon becoming Chief Justice in 1921, Taft continued to support the creation of his "flying squadron of judges," ${ }^{175}$ which was presented as draft legislation to Congress by the Attorney General. ${ }^{176}$ The concept was rebuffed, in part because opponents were concerned that the Chief Justice would dispatch judges supportive of the national edict on Prohibition to recalcitrant jurisdictions and in part because it undercut local

Sentelle, a former Republican party official, to head this division. See Ruger, The Judicial Appointment Power of the Chief Justice, supra note 31, at n.10 and accompanying text.

${ }^{172}$ Ruger, The Judicial Appointment Power of the Chief Justice, supra note 31, at 343.

${ }^{173}$ See Taft, Adequate Machinery for Judicial Business, supra note 69, at 454 (proposing the idea of "judges at large").

${ }^{174}$ Henry P. Chandler, Some Major Advances in the Federal Judicial System: 1922-1947, 31 F.R.D. 307, 322 (1963).

${ }^{175}$ See Ruger, The Judicial Appointment Power of the Chief Justice, supra note 31, at 356; Taft, The Possible and Needed Reforms in the Administration of Justice in Federal Courts, supra note 85 .

${ }^{176}$ See Additional Judges, U.S. District Courts: Hearings on S. 2432, 2433, 2523 Before the S. Comm. on the Judiciary, 67th Cong. 11 (1921). Taft is said to have drafted an initial version of this legislation but sought to keep a low profile. See Jeremy Buchman, Judicial Lobbying and the Politics of Judicial Structure: An Examination of the Judiciary Act of 1925, 24 JUST. SYS. J. 1, 9-14 (2003) (discussing Taft's strategic efforts to minimize his role); Walter F. Murphy, Chief Justice Taft and the Lower Court Bureaucracy: A Study in Judicial Administration, 24 J. POL. 453, 455 (1962) (describing Taft's role); see also 62 CONG. REC. 202 (1922) (statement of Sen. Walsh) (commenting that the proposal had been made by the Chief Justice and forwarded by him to the Senate and House Judiciary Committees). 
politicians' patronage possibilities. ${ }^{177}$ Understood then was the potential that the power to select appointees and to make assignments could affect the outcomes of cases.

Although Taft formally lost that fight, he won a congressional license for the Chief Justice to reassign judges (upon request of the borrowing court) temporarily from one court to serve on another. ${ }^{178}$ Several statutes now authorize "lending" practices within circuits, ${ }^{179}$ but only the Chief Justice can designate district and circuit court judges to serve on courts outside the circuits to which they are appointed. ${ }^{180}$ While the Chief Justice no longer does that work personally but relies instead on the Judicial Conference Committee on Intercircuit Assignments to approve requests, ${ }^{181}$ the Chief Justice appoints that committee and retains the power to allocate judges. ${ }^{182}$

More generally, and in conjunction with the Director of the AO, the Chief Justice appoints many committees, some of which are standing

${ }^{177}$ See, e.g., 62 CONG. REC. 4862 (1922) (statement of Sen. Shields) ("The action of the antisaloon interest in favoring this bill simply forecasts that its representatives will attempt to influence the Chief Justice to assign judges selected by them solely for the purpose of trying prohibition cases and without regard to the interest of other litigants of greater importance and the mass of the business pending in the courts."); id. at 4858 (statement of Sen. Shields) ("The Chief Justice has no more to do with the judges of the district courts of the United States, and with the trial of cases, and procedures in those courts, or the congestion of business in them, than does King George."); see also David H. Burton, William Howard Taft: In the Public Service 125-27 (1986); Murphy, supra note 176, at 458; Robert Post, Traditional Values and Positive Law: The Case of Prohibition in the Taft Court Era (unpublished manuscript, on file with the University of Pennsylvania Law Review).

${ }_{178}$ See Act of Sept. 14, 1922, ch. 306, § 3, 42 Stat. 837, 839.

179 See 28 U.S.C. $\$ \$ 291$ (b), 292(b) (2000).

${ }^{180}$ See id. $\$ 291$ (a) (providing for temporary transfer of circuit judges to other circuits); $i d . \S 292(\mathrm{~d})$ (providing for temporary transfer of district judges to act as circuit or district judges in other circuits or on the Court of International Trade); see also id. $\S 293$ (a) (authorizing the Chief Justice to transfer Court of International Trade judges temporarily to perform judicial duties in any circuit upon showing of need); $i d$. $\S 294$ (a) (authorizing the Chief Justice to assign willing and able retired Justices to perform judicial duties in any circuit); $i d$. $\$ 294(\mathrm{~b})$, (d) (authorizing the Chief Justice to assign senior judges to perform judicial duties in any circuit); 48 U.S.C. $\$ \S 1614$, 1821, 1424 (2000) (authorizing the Chief Justice to designate judges to sit on territorial courts in the Virgin Islands, the Northern Mariana Islands, and Guam, respectively). The Chief Justice may not assign an active judge to perform judicial duties in another circuit unless the chief judge of the circuit (or of the court in the case of the Court of International Trade) from which the judge will be transferred first consents. 28 U.S.C. $\S 295$ (2000). For further discussion of visiting judge practices and procedures in the federal district courts, see JENNIFER EVANS MARSH, THE USE OF VISITING JUDGES IN THE Federal District Courts: A Guide for Judges and Court Personnel (Fed. Jud. Ctr. 2001).

${ }^{181}$ Fish, Office of Chief Justice, supra note 3, at 110.
${ }^{182}$ See 28 U.S.C. $\$ \S 291-295,331$. 
committees of the Judicial Conference and others of which are groups convened (like the Ad Hoc Committee on Gender-Based Violence, discussed above ${ }^{183}$ ) to review a particular issue. As decades of scholarship about federal court rulemaking activities have made clear, a line between "practice and procedure" and "substantive rights" is hard to draw. ${ }^{184}$ As Judicial Conference committees craft rules that create or narrow opportunities for access to courts (through pleading and class action requirements, for example) or for information disclosure (through discovery and disclosure obligations), the range of opportunities for plaintiffs and defendants change. ${ }^{185}$ The appointment power gives the Chief Justice the ability to select particular people who shape these decisions.

Further, given that lower court judges average twenty-four years on the bench, ${ }^{186}$ the Chief Justice can also come to know the approaches of individual judges and to rely on some specially. Appointment powers thus permit the Chief to reward certain judges by putting them in the limelight (or the hotseat, depending on one's viewpoint)—as rulemakers, as opinion shapers, as adjudicators on specialized courts or courts in other federal jurisdictions, and as emissaries to Congress or to jurists from other jurisdictions. ${ }^{187}$ Because committee work can be interesting and enables those involved to step back from individual cases to consider structural issues, the Chief Justice has the ability to endow some jurists with significant social (or juridical) capital—and to marginalize others. ${ }^{18}$

\section{Additional and Peculiar Powers: From the Smithsonian to Garnishment}

A review of yet other statutory powers of the Chief Justice reveals an odd assortment of assignments running with the position. Some of the

${ }^{183}$ See supra notes 157-59 and accompanying text.

${ }^{184}$ See Lori A. Johnson, Creating Rules of Procedure for Federal Courts: Administrative Prerogative or Legislative Policymaking?, 24 JUST. SYS. J. 23, 23-24 (2003) (summarizing those debates).

${ }^{185}$ See Baar, supra note 113 (discussing Burger's appointments); Stempel, supra note 114 (discussing Rehnquist's appointments). Russell Wheeler noted that "Rehnquist no doubt favored Republican-appointed judges," but argued that considering data that focused on Conference committee chairs and excluded ad hoc committees, did so "not as much as meets the eye." Wheeler, Chief Justice Rehnquist, supra note 141 , at 118 .

${ }^{186}$ See supra Table 1, Lengths of Service of Article III Judges: Contrasting Snapshots, 1800 s/2000s.

187 See Little, supra note 57, at 737 ("Executive officials occasionally solicit nomination advice from present and former members of the judiciary.").

${ }^{188}$ Our concern is not that this is an unconstitutional delegation of power, but rather that it is an unwise allocation of power. See infra note 310 and accompanying text. 
duties relate to the judiciary, and others are further afield; ${ }^{189}$ many are delegated and given little attention. For example, Congress has authorized the Chief Justice to promulgate regulations on garnishment of the wages of members of the judicial branch. ${ }^{190}$ The Chief also has rulemaking power to prevent disclosure of classified information by the federal courts. ${ }^{191}$ Moving outside the federal courts (and potentially raising an important question of the power of Congress to do so), the Chief Justice approves selections of persons to sit on special North American Free Trade Agreement (NAFTA) dispute resolution panels. ${ }^{192}$ In terms of other kinds of appointment powers, the Chief Justice is statutorily assigned to designate two of the eleven members of the Citizens' Commission on Public Service and Compensation ${ }^{193}$ and one of the fifteen members of the National Historical Publications and Records Commission. $^{194}$

Congress has also authorized the Chief Justice to assist the Library of Congress in purchasing books for the law library ${ }^{195}$ and to recommend individuals to serve on the Board of Trustees of the James Madison Memorial Fellowship Foundation. ${ }^{196}$ In addition, the Chief Justice serves on various boards, including the Smithsonian Institution (of which, through custom, the Chief Justice serves as chancellor), ${ }^{197}$ the National Gallery of Art, ${ }^{198}$ and the Hirshhorn Museum and Sculpture Garden. ${ }^{199}$ Some Chief Justices take on more; Warren Burger served as an honorary chairman of

${ }^{189}$ See infra Appendix B, Statutory Duties of the Chief Justice of the United States.

${ }^{190}$ See 5 U.S.C. $\$ 5520 \mathrm{a}(\mathrm{J})(1)(\mathrm{e})$ (2000) (expressly allowing the Chief Justice to delegate this authority).

191 U.S.C. app. $\$ 9(2000)$.

19219 U.S.C. $\$ 3432(2000)$.

1932 U.S.C. $\$ 352(2000)$.

19444 U.S.C. $\S 2501$ (2000).

1952 U.S.C. $\$ 135(2000)$.

19620 U.S.C. $\$ 4502$ (2000).

${ }^{197}$ Id. $\$ 41$; see Act of Aug. 10, 1846, 9 Stat. 102 (establishing the Smithsonian Institution and designating the Chief Justice a constituting member of that organization and a member of its Board of Regents). While not specified, the tradition has been that the Chief serves as chair. See Tamm \& Reardon, supra note 17, at 450.

${ }^{198} 20$ U.S.C. $\$ 72$ (2000); see Act of Mar. 24, 1937, 50 Stat. 51, 52 (establishing the National Gallery of Art and stating that its board "shall be composed as follows: The Chief Justice of the United States, the Secretary of State, the Secretary of the Treasury, and the Secretary of the Smithsonian Institution, ex officio; and five general trustees who shall be citizens of the United States, to be chosen as hereinafter provided").

19920 U.S.C. § 76cc (2000); see Act of Nov. 7, 1966, Pub. L. No. 89-788, § 3, 80 Stat. 1403, 1404 (Nov. 7, 1966) (establishing the Hirshhorn Museum and Sculpture Garden and providing that its "Board of Trustees shall be composed of the Chief Justice of the United States and the Secretary of the Smithsonian Institution, who shall serve as ex officio members, and eight general members"). 
the Supreme Court Historical Society and on various other boards. ${ }^{200}$ Chief Justices also take time to visit law schools, to attend circuit conferences, and to be a presence in many venues around the country and the world. These tasks may seem trivial or ceremonial, but according to those who have served within the judiciary, the work-for example, chairing the Smithsonian Board-involves real contributions of time and energy. $^{201}$

Further, as is familiar, Presidents have sometimes turned to Chief Justices to take on other tasks. ${ }^{202}$ Twentieth-century examples include chairing investigations such as the 1960s Warren Commission inquiry into the assassination of President Kennedy and arbitrating border disputes in the 1930s between Guatemala and Honduras. ${ }^{203}$ In short, just as the Chief Justice is both a "boss" and a symbol of the Supreme Court, the Chief Justice is also a practical as well as an iconic leader of the federal judiciary. Time and again, individual Chief Justices have proven to be the judiciary's most effective lobbyists, the judiciary's most visible spokespersons, and the nation's most important judicial leaders.

\section{The ANOMALY OF LIFE-TENURED MULTI-TASKING}

\section{A. Mixing Roles}

The concentration of the powers of adjudication and administration in the chief justiceship prompts questions about how one role affects the other. Through the obligation to multi-task, the Chief Justice is distracted from being either a full-time adjudicator or administrator. When the two roles are combined, a well-intentioned and astute Chief Justice, aiming to forward only legally appropriate policy proposals, has to think

${ }^{200}$ Tamm \& Reardon, supra note 17 , at 451 .

${ }^{201}$ See Comment of Jeffrey Morris, 1982 Virginia Conference, supra note 3, at 16768 (describing the "relentlessness" of the Chief Justice's many ceremonial, diplomatic, managerial, and other tasks). Morris, who served as a Judicial Fellow and Research Associate during Chief Justice Burger's term, offered as examples the countless jurists from other countries that Chief Justice Burger entertained and his attendance in September of 1980 at a two-day meeting of the Smithsonian Board of Regents, followed by a two-and-a-half day meeting of the Judicial Conference, shortly before the Court's 1980-1981 Term began.

${ }^{202}$ In the early days of the Republic, Chief Justices undertook significant extrajudicial duties. Chief Justices Jay and Ellsworth, for example, served as the foreign ambassadors to England and France, respectively, and Marshall concurrently acted as Chief Justice and as Secretary of State. See Wexler, supra note 48; Russell Wheeler, Extrajudicial Activities of the Early Supreme Court, 1973 SUP. CT. REV. 123, 123 (1973).

${ }^{203}$ Robert P. McKay, The Judiciary and Nonjudicial Activities, 35 L. \& ConTEMP. Probs. 9, 32, 34-35 (1970). 
simultaneously about the administratively desirable, the politically feasible, and the constitutionally plausible.

But none of those categories exists ex ante. Adjudication can reframe administrative possibilities, just as administration can make clear why constitutional parameters ought to be reexamined. As is analyzed below, the interaction between roles is complex and at times contradictory, as the amalgam both amplifies the power of the individual serving as the Chief at a potential cost to the collective power of the Court and puts at risk the disinterested quality required of adjudication.

One worry is distraction: in principle, being a Justice is a full-time position. Given the expanding demands of the chief justiceship, the person so denominated becomes both a part-time Justice and a part-time administrator-neither of which is desirable, as Phillip Kurland noted in the early 1970s. ${ }^{204}$ And whatever choices Associate Justices make to travel, lecture, or write, the portfolio they select is of their own choosing, with a flexibility that the Chief Justice as administrator does not have.

Hence, one kind of critique is managerial. The Chief Justice's current tasks-ceremonial head, diplomat, manager, speaker, planner, career-enhancer, policymaker, adjudicator, intellectual leader, CEO, trustee, rulemaker, museum trustee-are implausible from a bureaucratic perspective. ${ }^{205}$ In personal terms, the challenge of endurance has been noted repeatedly by those close to the process. Warren Burger himself described how he spent "four to six hours a day on administrative matters apart from my judicial work" and that such a schedule was "not possible—not physically possible—to continue" for too long. ${ }^{206}$

${ }^{204}$ Philip B. Kurland, The Lord Chancellor of the United States, TRIAL, Nov.-Dec. 1971, at 11, 28 (arguing that the Chief Justice of the United States is "not particularly well equipped ... to supervise substantive or procedural law reform throughout the nation").

${ }^{205}$ See, e.g., Daniel J. Meador, The Federal Judiciary and Its Future Administration, 65 VA. L. REV. 1031, 1041-44 (1979) (describing the Chief Justice's duties and concluding that "[i]t requires no empirical data beyond that already available to conclude that the array of duties involved in administering the entire judicial system, combined with the responsibility of presiding over and participating in the adjudicative business of the Supreme Court, places upon the Chief Justice a workload that can be carried only by one of nearly superhuman energy"); see also Wheeler, Chief Justice Rehnquist, supra note 141, at 120 (predicting that the Chief Justice's considerable administrative power will at some point require a shifting of some duties to the Judicial Conference or the Supreme Court).

${ }^{206}$ Landever, supra note 102, at 530-31 (citing Exclusive-Interview with the Chief Justice, U.S. NEWS \& WORLD REP., Dec. 14, 1970, at 32, 44) (emphasis added by Landever omitted); see also Chief Justice Warren E. Burger, Address at the American Enterprise Institute for Public Policy Research's Conference on the Role of the Judiciary in America (Dec. 14, 1978), quoted in Meador, The Federal Judiciary and Its Future Administration, supra note 205, at 1044 ("If the burdens of this office continue to increase as 
Of course, in practice, the Chief Justice delegates to others, but unlike dozens of comparable federal positions regulated by statutes requiring senatorial confirmation, ${ }^{207}$ the three high-level officials in the judiciary's bureaucracy obtain their jobs through the Chief Justice. The first, the Director of the AO, is the most powerful. ${ }^{208}$ While outsiders may have little sense of the managerial authority of the Director, insiders-including life-tenured judges-have found themselves constrained by policies promulgated by the Director who, if protected by the Chief Justice, may be able to prevail over disgruntled Article III judges. A rare public glimpse of this form of conflict occurred when, without notification, the AO began to monitor judges' computers to learn about personal use, having "installed software to detect downloading of music, streaming video, and pornography." ${ }^{209}$

A second important position, created in 1972 at Chief Justice Burger's behest, is the Administrative Assistant to the Chief Justice, a position designed to "relieve the Chief Justice of many of the timeconsuming details involved in the nonadjudicative responsibilities of the office." ${ }^{210}$ Apparently, concern about the degree of authority devolved

they have in past years, it may be impossible for the occupant to perform all the duties well and survive very long."). At the 1982 roundtable at the University of Virginia, a retired executive, who joined a group of law professors, government officials, and practicing lawyers, was debriefed by members of Chief Justice Burger's staff about the scope of the job; the businessman commented that he thought the job "physically impossible." See 1982 Virginia Conference, supra note 3, at 189 (statement of J. Wilson Newman, former Chairman and CEO, Dun \& Bradstreet). Mark Cannon, the Chief Justice's Administrative Assistant, also described the "relentlessness of the job" of the Chief Justice. Id. at 170 (statement of Mark Cannon); see also Jack B. Weinstein, The Role of the Chief Judge in a Modern System of Justice, reprinted in JUDICIAL ADMINISTRATION, supra note 104, at 144 (proposing that the chief jurist should have fewer opinions to write than other judges on a court and ought to delegate more to others).

${ }^{207}$ For example, within the Department of Justice and in addition to the Attorney General, several other high ranking officers (the Deputy Attorney General, the Solicitor General, the Inspector General, the Associate Attorney General, and various Assistant Attorney Generals) are presidential nominees requiring senatorial confirmation. The United States Attorneys and United States Marshals in each district do, as well. See 28 U.S.C. $\$ \S 503,504,504 a, 505,506,507,541,561$ (2000).

${ }^{208}$ As Appendix A, The Tenure of Chief Justices of the United States, of Directors of the Administrative Office of the U.S. Courts, and of Directors of the Federal Judicial Center, makes plain, the Director's tenure is tied to the Chief Justice's. See also supra note 84 (discussing close relationships between Chief Justices and Directors of the AO).

${ }^{209}$ See Neil A. Lewis, Rebels in Black Robes Recoil at Surveillance of Computers, N.Y. TIMES, Aug. 8, 2001, at A12 (reporting that Judge Kozinski drafted and distributed an "18-page legal memorandum arguing that the monitoring was a violation of [an] antiwiretap statute"); Wasby, supra note 58, at 471-74 (detailing the episode).

${ }^{210}$ S. REP. NO. 92-616 (1972), as reprinted in 1972 U.S.C.C.A.N. 1977, 1979; see Act of Mar. 1, 1972, Pub. L. No. 92-238, 86 Stat. 46 (codified as amended at 28 U.S.C. $§ 677$ (2000)); see also S. REP. NO. 92-616, as reprinted in 1972 U.S.C.C.A.N. at 1977-80 (discuss- 
under Chief Justice Burger to a single individual (Mark Cannon, who held the position for many years), prompted Chief Justice Rehnquist to limit the term of his own Administrative Assistants somewhat. ${ }^{211}$

The third position, Director of the Federal Judicial Center, came into being in 1967 when the FJC was established. ${ }^{212}$ The Chief Justice chairs the FJC's nine-member Board ${ }^{213}$ that selects the Director. The custom has developed that the Director serves a limited term, ranging from about four to seven years. ${ }^{214}$ Retired Justice Tom Clark took that post first, and he has been followed by one law professor and several Article III judges, all of whom have enjoyed more independence than many other senior administrators.

The Chief Justice has also been in the position to mediate the tensions that have arisen between the authority of the AO and the FJC, whose mandates overlap to some degree. As a reporter covering a dispute in the mid-1990s put it, both the AO and the FJC "serve the same masters: Chief Justice William Rehnquist, the U.S. Judicial Conference, and almost 2,000 federal judges." ${ }^{215}$ That article quotes the AO Director

ing the many "nonadjudicative responsibilities" of the Chief Justice and explaining that an administrative assistant could relieve the Chief Justice in a relationship that would be "a close one involving constant and personal contact, some of it of a confidential nature"); Letter from Rowland Kirks, Director of the Administrative Office, to Spiro Agnew, President of the Senate (Mar. 6, 1971), as reprinted in 1972 U.S.C.C.A.N. at 1980-81 (transmitting a draft bill to create the office). By statute, the position has a salary not to exceed that of the Director of the Administrative Office of the United States Courts. 28 U.S.C. $\$ 677(\mathrm{a})$. For descriptions of some of the work performed by the Administrative Assistant, see Mark W. Cannon \& Warren I. Cikins, Interbranch Cooperation in Improving the Administration of Justice: A Major Innovation, 38 WASH. \& LEE L. REV. 1, 8 (1981).

${ }^{211}$ Mark Cannon acted as Administrative Assistant for fourteen years-from 1972 (when the position was created) to 1986, the end of Chief Justice Burger's tenure. In contrast, several of Chief Justice Rehnquist's Administrative Assistants held the position for two-year terms. See Charles Lane, Serving in the Chief Justice's Shadow, WASH. PoST., Feb. 7, 2005, at A19. Rehnquist's last Administrative Assistants, James Duff and Sally Rider, served for four and five years, respectively. See id at A19.

${ }^{212}$ See 28 U.S.C. $\$ 620$ (2000).

${ }^{213}$ In addition to the Chief Justice, the Director of the Administrative Office and seven judges (two circuit judges, three district judges, one bankruptcy judge, and one magistrate judge) elected by the Judicial Conference sit on the Federal Judicial Center Board. 28 U.S.C. $\$ 621$ (a). While the Chief Justice and the Director of the AO are permanent members, the seven elected judges serve four-year terms and may not be reelected. Id. $\S 621(\mathrm{~b})-(\mathrm{c})$.

${ }^{214}$ See infra Appendix A, Tenure of Chief Justices of the United States, of Directors of the Administrative Office of the U.S. Courts, and of Directors of the Federal Judicial Center.

${ }^{215}$ See Robert Schmidt, A Turf War Over Training Judges, LEGAL TIMES, Sept. 29, 1997, at 1 (discussing the "turf" battle in which, as funds for the judiciary became tighter, the FJC and the $\mathrm{AO}$ vied for support). 
as calling for the abolition of the FJC as an independent entity, and describing the FJC as an "agency out of control ... with its own agenda that has at times opposed the Judicial Conference." ${ }^{216}$ Chief Justice Rehnquist reportedly supported the FJC, and an ad hoc Judicial Conference committee, appointed by the Chief Justice, thereafter rejected the suggestion to fold the FJC into the AO. ${ }^{217}$ In short, the federal judiciary has attributes familiar to many bureaucracies, complete with internal disputes and power struggles whose outcomes are affected by the Chief Justice, who as the CEO, can choose how involved to be in the policymaking of these subdivisions of the judiciary.

As the thicker description of the administrative apparatus of the federal judiciary makes plain, the Chief Justice has a significant amount of work, even if minimally involved in superintending the judicial enterprise. One problem is that the two sides of the job, adjudication and administration, compete with each other for time and attention. Another concern is that each role constrains and influences the other in ways that can be undesirable. For example, however insistent Warren Burger might have been as a lobbyist, he did not have available to him all of the persuasive techniques that other lobbyists have used. ${ }^{218}$ Being an adjudicator ought to hamstring how the Chief Justice functions as a political operative, ${ }^{219}$ for, unlike others who walk the halls at the Hill to garner support or opposition for particular legislative initiatives, the Chief should have few promises or threats to make. However, once attuned to administrative challenges, the Chief Justice as adjudicator may see more readily why doctrine should change to make possible functional responses (such as delegation of tasks to non-life-tenured judges) to truly challenging problems (such as too many cases).

On top of distraction and constraint, the dual roles also permit amplification of authority. While synergy is often applauded, here it poses problems of various sorts. For Chief Justices who stay long enough in that office, the capacity to maneuver administratively as well as through adjudication may give the Chief forms of leverage that could encroach on the power of the Supreme Court itself. A Chief Justice's ability to use

${ }^{216} I d$. at 1; see id. (discussing the FJC's creation, in response to the conflict, of its own strategic planning committee, which noted that the FJC's "research activity, or at least the manner of its dissemination, has been at odds with the judiciary's efforts to develop consistent policy on important issues and present that policy in a coherent manner").

${ }^{217}$ See Admin. OfFice of THE U.S. Courts, Report OF the Proceedings OF THE JUdiCIAL CONFERENCE (Mar. 10, 1998).

${ }^{218}$ See Charles Gardner Geyh, Paradise Lost, Paridigm Found: Redefining the Judiciary's Imperiled Role in Congress, 71 N.Y.U. L. REv. 1165, 1221-22 (1996).

${ }^{219}$ See id. at 1191-1206 (considering whether constitutional and ethical constraints proscribe lobbying authority). 
administrative directives and programs to reframe legal parameters can undercut caselaw generated through collaborative efforts of the other Justices.

Further, a Chief Justice can shape the Court's doctrine to make feasible certain kinds of administrative innovations that once seemed legally troubling. Examples include Chief Justice Burger's insistence on delegation of authority to judges without life tenure, ${ }^{220}$ and Chief Justice Rehnquist's efforts to restrict habeas corpus through rulemaking. ${ }^{221} \mathrm{Al}-$ though initially faced with what commentators have styled a "revolt" or "rebuff" in the Judicial Conference, Rehnquist was able-by staying focused over many years-to limit habeas petitions through Court-made doctrine and interpretations of congressional legislation. ${ }^{222}$

Yet, as the Chief Justice gains power, erosion of certain other forms of authority is also a risk. Chief Justice Hughes (whose term, from 1930 to 1941 , spanned a period before and after the 1939 creation of the Administrative Office) is identified with raising the concern that administration and lobbying involve judges in political conflicts that could potentially undermine the understanding that the Court's decisions are legally, rather than politically, motivated. ${ }^{223}$ Hughes also worried that,

${ }^{220}$ See Countryman, supra note 144, at 7-12 (discussing Burger's activities related to bankruptcy legislation). Chief Justice Burger also sought-administratively and adjudicatively - to enhance the authority of magistrates, who in 1990 gained the title "magistrate judge." In 1975, Chief Justice Burger gave a speech arguing that " $[\mathrm{t}]$ he statutes relating to United States magistrates should be clarified to give them broader powers, subject to final decision by a district judge, in order to release district judges for fullscale trials." Warren E. Burger, Annual Report on the State of the Judiciary, Remarks of Warren E. Burger, Chief Justice of the United States, Before the American Bar Association 7-8 (Feb. 23. 1975), reprinted in ANNUAL REPORTS OF THE CHIEF JUSTICE, supra note 108. A year earlier, he had argued in dissent:

The Federal Magistrates Act was both "designed to create an upgraded lower tier judicial office," and "intended ... to cull from the ever-growing workload of the U.S. district courts matters that are more desirably performed by a lower tier of judicial officers." The Court's holding that federal magistrates may not conduct evidentiary hearings in federal habeas corpus cases is both inconsistent with the new status of magistrates ... and serves to defeat the objective of the Act, described by Senator Tydings, its principal sponsor, "to provide district judges with more time to devote to the actual trial of cases and the writing of opinions."

Wingo v. Wedding, 418 U.S. 461, 475-76 (1974) (Burger, C.J., dissenting) (citations omitted).

${ }^{221}$ See Linda Greenhouse, Vote Is a Rebuff for Chief Justice, N.Y. TIMES, Mar. 15, 1990, at A16 (describing that the Judicial Conference as a whole modified proposals, which had been made by a special committee appointed by the Chief Justice, to limit habeas corpus).

${ }^{222}$ See Wasby, supra note 58, at 464-71; Greenhouse, supra note 221, at A16.

${ }^{223}$ See supra note 31 and accompanying text. 
were any misbehavior of judges or staff in lower courts to occur, the linking of the lower and high courts through the AO could tarnish the image of the Supreme Court. ${ }^{224}$ Hughes may have been particularly sensitive to hostility directed at judges, as he came into the position of Chief Justice not long after Congress had debated whether to create a Conference of Senior Circuit Judges. One member of the House had warned that such a group would be a "propaganda organization for legislation for the benefit of the Federal judiciary," "self-seeking," and aimed at performing "a legislative function" incompatible with judicial work. $^{225}$ Further, during Hughes' tenure, a painful debate took place about the constitutionality of the New Deal and of the Court-packing plan.

On several occasions, Chief Justice Hughes counseled caution in the judiciary developing an administrative apparatus and speaking in unity. For example, in the early 1930s, members of Congress proposed the abolition of diversity jurisdiction. ${ }^{226}$ During that era, progressives saw the federal courts as bastions of property interests and as hostile to unions. Moreover, federal enforcement of Prohibition was yet another source of antipathy from some towards the federal judiciary. In terms of the specific question of diversity jurisdiction, as Edward Purcell has explained, corporate defendants were able to remove cases from state courts to federal courts and thereby to impose significant litigation costs on less wellto-do plaintiffs. ${ }^{227}$

While progressives therefore sought to limit resort to the federal courts, many federal jurists were proponents of diversity jurisdiction, which represented a significant percentage of the federal docket and which, until Erie Railroad Co. v. Tompkins, ${ }^{228}$ was also a major source of federal lawmaking. ${ }^{229}$ Despite that judicial enthusiasm for and interest in

${ }^{224}$ FISH, supra note 65, at 136-37; see also id. at 114 (noting that "the public behavior of some judges," including that of a Second Circuit judge who reportedly accepted bribes, fueled congressional antipathy toward the judiciary during the 1930s).

${ }^{225} 62$ CONG. REC. 202-03 (1921) (statement of Rep. Lea).

${ }^{226}$ See Limiting Jurisdiction of Federal Courts, Hearings on S. 937, S. 939, and S. 3243 Before Subcomm. of S. Comm. on the Judiciary, 72d Cong. 1-25 (1932).

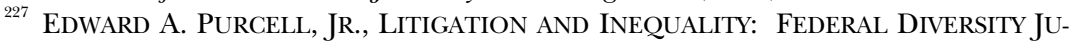
RISDICTION IN INDUSTRIAL AMERICA, 1870-1958, at 20-27 (1992).

${ }^{228} 304$ U.S. 64 (1938).

${ }^{229}$ Indeed, a 1951 committee report reaffirmed that position, explaining that "diversity jurisdiction has been recognized from the beginning as essential to the proper administration of justice under the dual sovereignty established by our Constitution." Report of the Committee on Venue and Jurisdiction of the Judicial Conference, at 6, 11, in Judicial Conference Meetings Records, RG 116, supra note 88, Box 54 (Mar. 1951-Sept. 1951). This study committee, chaired by Judge John Parker of the Fourth Circuit, came into being because of renewed proposals to abolish diversity jurisdiction. 
protecting diversity jurisdiction, Chief Justice Hughes argued that it would not be wise for the Conference to advance a collective viewpoint. To record opposition formally would, he explained, put judges in a "very vulnerable position" that would "weaken ... their prestige, and their independence, if they appeared to be campaigning in their own interests." ${ }^{230}$ Hughes urged that individual judges make contact with bar associations but that no collective action be undertaken. Similarly, in the wake of the Court-packing controversy, when the Administrative Office was created in $1939,{ }^{231}$ Hughes was hesitant, again seeing the risk that administrative agendas or errors could reflect negatively on the Court. ${ }^{232}$

Yet, as the discussion above of the positions taken by Chief Justices Burger and Rehnquist illustrates, ${ }^{233}$ the approach of Chief Justice Hughes has been replaced by a very different stance. The Conference now regularly records its views. Moreover, rather than protest against divesting the federal courts of jurisdiction, the Judicial Conference, with Chief Justices Burger and Rehnquist at its helm, has supported divestiture of many forms of federal jurisdiction, diversity included. ${ }^{234}$ Further (and in some respects as Chief Justice Hughes feared), we have gained the capacity to compare administrative stances and adjudicative outcomes. We can review, for example, Chief Justice Rehnquist's comments in speeches, the Judicial Conference's calls under his leadership for retrenchment in federal jurisdiction, both civil and criminal, and the con-

${ }^{230} 1932$ Transcript at 241-42, in Judicial Conference Meetings Records, RG 116, supra note 88, Entry 4; see also FISH, supra note 65, at 69 (recounting that position).

${ }^{231}$ See Peter Graham Fish, Crises, Politics, and Federal Judicial Reform: The Administrative Office Act of 1939, 32 J. POL. 599, 604-07 (1970) (arguing that struggles over status, including the failed Court-packing effort, prompted judges to be interested in controlling their own administration); FISH, supra note 65, at 124 (quoting Hearings on S. 188 Before the Subcomm. of the S. Comm. on the Judiciary, 76th Cong. 9 (1939) (statement of D. Lawrence Groner)) (stating that judges moved to "cclean their own house, rather than be subject to the embarrassment and destruction of our theory of government by having it done by someone else"”).

${ }^{232}$ See FiSH, supra note 65, at 127-28.

${ }^{233}$ See supra Part II.B.2.

${ }^{234}$ ADMIN. OFFICE OF THE U.S. COURTS, REPORT OF THE PROCEEDINGS OF THE JUDICIAL CONFERENCE 8-9, 52 (1977); Warren E. Burger, Year-End Report on the Federal Judiciary 3-4 (Jan. 1, 1978), reprinted in ANNUAL REPORTS OF THE CHIEF JUSTICE, supra note 108 (stating that the House Judiciary Subcommittee on Courts, Civil Liberties, and the Administration of Justice had reported a bill "curtailing a large segment of [diversity] jurisdiction" and opining that "[w]ith few exceptions, [diversity] cases belong in the State courts and their transfer from 397 Federal district judges to approximately 6,000 State court judges of general jurisdiction will impose no significant new load on the State courts"). 
stitutional decisions in cases such as United States $v$. Lopez $^{235}$ and United States v. Morrison. ${ }^{236}$ In both of those decisions, the Chief Justice was part of a bare majority concluding that Congress lacked the constitutional power to confer jurisdiction on the federal courts over the kind of claims the "administrative" judiciary had advocated be curtailed.

In addition to the amplification of certain forms of authority at a cost to (or erosion of) other forms of authority, another kind of problem is the well-intended but inappropriate conflation of the administratively desirable with the legally permissible. If the federal bench did not exercise the power of judicial review, then perhaps judicial consideration of pending legislation on topics including the Court's own authority would be less troubling. Moreover, such advisory processes could be formalized and regulated, as is illustrated by the practices in France of its Conseil Constitutionnel, which has a fixed period of time to consider a law's legality before that provision becomes effective. ${ }^{237}$ There, the Conseil's charge is to render legal judgments on a law's permissibility, not its desirability.

In contrast, the criteria for Judicial Conference evaluation are unspecified, leaving unclear what metrics are used. While one might balk at the Conference offering its opinion on the constitutionality of a law, that seems the most appropriate (if legally off-putting) tack to take, for the added value provided by judges comes from their expertise on the law rather than from a subset of judges assessing a proposed law's potential trade-offs or utilities-tasks which are within the bailiwick of the legislative branch. Yet the Judicial Conference and the Chief Justice do not discuss directly the constitutionality of proposed bills but often comment instead on the bills' wisdom and the possible effects such enactments could have on their workload.

The two roles (advisor ex ante and adjudicator ex post) cannot help but bleed into one another. Many important legal questions are inde-

${ }^{235} 514$ U.S. 549, 567-68 (1995) (holding that Congress exceeded its power under the Commerce Clause when, in the Gun Free School Zones Act, it made it a federal offense to knowingly possess a firearm in a local school zone).

${ }^{236} 529$ U.S. 598 (2000); see also supra notes 156-64 and accompanying text (discussing Morrison).

${ }^{237} 1958$ CONST. art. 61 (Fr.) (providing for the Conseil Constitutionnel's preimplementation review of legislation). French law provides a separate entity-the Conseil Constitutionnel-to consider the constitutionality of laws. The Conseil reviews Acts of Parliament after they are approved but before publication. Once a law has passed through or by the Conseil, the French courts have no power to strike it down on grounds of illegality. See generally Roger Pinto, Elisabeth Zoller, Henri Ader, \& Wallace Baker, A Primer on French Constitutional Law and the French Court System, 5 TUL. J. INT'L \& COMP. L. 365, 368-74 (1997). 
terminate, with answers changing over time. One such example is the issue on which Chief Justice Burger spent much of his personal capitallife tenure for bankruptcy judges. The question was (and remains) how much of the power of judgment should and can constitutionally be devolved to federal adjudicators who lack the Article III attributes of life tenure and protected salaries. As an administrator, Chief Justice Burger did not want bankruptcy judges to have life tenure. Of the various reasons that he and others proffered, one major argument was (and is) that qualified individuals would not be interested in Article III judgeships if too many slots were open. ${ }^{238}$ As an adjudicator, Burger believed-unlike other members of the Court who found the 1978 bankruptcy reforms gave too much power to non-tenured judges-that the broad grant of jurisdictional authority was constitutional. ${ }^{239}$ His views as the chief administrator, appropriately attuned to the needs of the federal courts, may well have affected his understanding of the constitutionality of outsourcing adjudication to non-Article III actors. Indeed, he should not have supported any administrative innovation that he thought was not constitutionally viable.

Just as synergy is typically extolled but here does harm, so too multitasking is often celebrated but here has a negative effect. Were the job of adjudication not so peculiar, the rich repertoire of prerogatives of the Chief Justice would be less troubling (holding aside the problems of concentration of power, which raise different kinds of concerns in democratic polities, as is discussed below). But adjudication is purposefully unlike other forms of decisionmaking. Judging is a role that, when fully inhabited, situates the person so endowed both with unusual power over other persons' lives and property and with unusual constraints, in terms of the kind and nature of information received and the kinds of discourse permitted. Ethics rules and customs seek to extract judges from other activities in order to enshrine role delineations that are much harsher than those of many other government posts. ${ }^{240}$ Yet the Chief

\footnotetext{
${ }^{238}$ See Countryman, supra note 144 , at 9 (observing that some argued that increasing the number of Article III judges would "dilute" the status of those positions).

${ }^{239}$ See N. Pipeline Constr. Co. v. Marathon Pipe Line Co., 458 U.S. 50, 92 (1982) (Burger, C.J., dissenting).

${ }^{240}$ See MODEL CODE OF JUdicial CONDUCT (2004), available at http:// www.abanet.org/cpr/mcjc/mcjc_home.html (last visited Mar. 30, 2006); CODE OF CONDUCT FOR UNITED STATES JUDGES, available at http://www.uscourts.gov/guide/vol2/ ch1.html (last visited Mar. 30, 2006). The Code of Conduct for United States Judges, adopted by the Judicial Conference, requires, for example, that judges refrain from engaging in political activities and admonishes judges against commenting on the merits of pending actions or participating in extrajudicial activities that might create an actual conflict in a current or future proceeding or even an appearance of impropri-
} 
Justice, the most visible icon of adjudication in the country, is now the least protected from having to function in realms appropriately labeled political.

\section{B. Undue Accumulations of Power}

The packet of powers now possessed by the Chief Justice is thus unduly enabling and also disabling, with one set of tasks either constraining or invading the work to be done under the other rubric. In addition, the concentration of power undermines democratic governance that is committed to distributing and accounting for power.

The distance between the Chief Justice's packet of powers, as it has evolved in the United States, and those of other high court justices, illuminates the anomalous American federal position. Take the length of tenure. $^{241}$ Many other democracies shape the mandate of their high court jurists by requiring either retirement at a fixed age or a term of office limited to a specified number of years. ${ }^{242}$ For example, both Australia and Israel set the age of retirement at seventy, ${ }^{243}$ and India requires its Supreme Court judges to step down at sixty-five. ${ }^{244}$ In Canada, mandatory retirement comes at seventy-five. ${ }^{245}$ The constitutional courts of

ety. See id. The Code allows judges to engage in extrajudicial activities to "improve the law, the legal system, and the administration of justice" so long as doing so "does not cast reasonable doubt on the capacity to decide impartially any issue that may come before the judge." Id. at Canon 4 .

${ }^{241}$ A different cut has been offered by political scientist Kevin McGuire, who details that, holding aside some highs and lows, the median term for Justices on the Supreme Court tends to be about fifteen years. See Kevin T. McGuire, Are Justices Serving Too Long? An Assessment of Tenure on the U.S. Supreme Court, 89 JUDICATURE 8, 12 (2005).

${ }^{242}$ See Lee Epstein, Jack Knight \& Olga Shvetsova, Comparing Judicial Selection Systems, 10 WM. \& MARY BILL RTS. J. 7, 23 (2001).

${ }^{243}$ Until 1977, when the Constitution was amended by a referendum, Australian High Court judges were appointed for life; judges appointed after the date of that amendment serve until the age of seventy. See AUSTL. CONST. ch. III, $\$ 72$ ("The appointment of a Justice of the High Court shall be for a term expiring upon his attaining the age of seventy years, and a person shall not be appointed as a Justice of the High Court if he has attained that age."); see also id. (providing that judges of "other courts created by the Parliament," that is the federal courts, must also retire at age seventy). Israeli law has a similar requirement. See Basic Law: The Judiciary, 57441984, 38 LSI 101, §§ 1-24 (Isr.) (providing for judges' terms to end upon resignation, removal, or "retirement on pension," now set at seventy years); see also The State of Israel, The Judicial Authority, http://elyon1.court.gov.il/eng/system/index.html (follow "The Judges" hyperlink) (last visited May 7, 2006).

${ }^{244}$ INDIA CONST. pt. 5, ch. $4, \S 124, \mathrm{cl} .2$.

${ }^{245}$ Supreme Court Act, R.S.C., ch. S-26 § 9(2) (1985) (Can.) (“A judge shall cease to hold office on attaining the age of seventy-five years."). 
Germany and France rely on another system: fixed terms. ${ }^{246}$ The new International Criminal Court has adopted that model, providing for a nine-year non-renewable term. ${ }^{247}$ Within the United States, Massachusetts, Vermont, New Jersey, and New Hampshire authorize lifetime judgeships, yet also require retirement at age seventy. ${ }^{248}$

Moreover, the chief justiceship's mixture of an unending term and so much unfettered and relatively invisible discretion is not readily assimilated into either the model of adjudication or administration. ${ }^{249} \mathrm{Ju}$ rists on appellate courts work collectively; they must persuade others of the correctness of their views in order to prevail. And because both constitutional and common law traditions mandate openness in courts, most decisions are explained by reasons that are available to public scrutiny and then revisited as new cases arise. In contrast, the administrative powers of the Chief Justice are neither officially shared nor constrained by obligations of accounting other than very general reports to Congress.

The many grants of power to the Chief Justice contrast sharply with the shape of authority of other executive officials. Even as we currently have a President who asserts extraordinary powers, he still cannot continue in office beyond the end of his second term. Heads of independent agencies generally also have limited terms, and cabinet members serve at the pleasure of the President. But currently, the Chief Justice

${ }^{246}$ In Germany, judges serve for a twelve-year nonrenewable term. Bundesverfassungsgericht [Federal Constitutional Court], Mar. 12, 1951, BGBl.I at 243, last amended by Gesetz, July 16, 1998, BGBl.I at 1823 (F.R.G.). In France's special constitutional body, the Conseil Constitutionnel, members serve for a nine-year, nonrenewable term. See 1958 CONST. art. 56 (Fr.).

${ }^{247}$ Rome Statute of the International Criminal Court art. 36, July 17, 1998, 2187 U.N.T.S. 90 (describing the initial election of judges with staggered terms and other than those selected through that initial process, generally prohibiting the service in office of more than nine years and barring eligibility for reelection).

${ }^{248}$ Massachusetts's 1780 constitution was amended in 1972 to include a retirement provision. MASS. CONST. amend. art. XCVIII. New Hampshire's constitution has, since 1792, required judges to retire at the age of seventy. N.H. CONST. pt. 2, art. 78. In New Jersey, judges and justices serve for a seven-year term and, once reappointed, obtain life tenure with mandatory retirement at seventy. N.J. ConsT. art. VI, § VI. In Vermont, after selection by appointment, the mandatory retirement age is "not less than seventy years of age, as the General Assembly may prescribe by law, or, if the General Assembly has not so provided by law, at the end of the calendar year or at the end of the term of election" in which the judge turns seventy. Retired judges may serve by appointment for special assignments. VT. CONST. ch. II, § 35. In contrast, Rhode Island imposes no time or age limits, instead providing justices on its supreme court with service during "good behavior." R.I. CONST. art. 10, § 5; see also infra Appendix C, Tenure and Methods of Selection of State Chief Justices.

${ }^{249}$ Judith Resnik \& Theodore Ruger, Op-Ed., One Robe, Two Hats, N.Y. TiMES, July 17, 2005, § 4, at Week in Review 13; see generally Resnik, Democratic Responses, supra note 1. 
has lifetime consolidated authority over the administration of both the Supreme Court and the lower federal courts, and does not have legal obligations to share that power with other jurists or administrators, nor to explain decisions made.

Further, in contrast to increased insistence on accountability for, and transparency in, governance, the chief justiceship has accumulated, during the twentieth century, power that is neither easily seen nor required to be explained. As Ronald Dworkin has suggested, during the nineteenth century, parliamentary processes were seen as best expressing the hopes of democracy; such faith was, however, undermined by the rise through majoritarianism of fascism. ${ }^{250}$ In response, and around the world, countries have turned to judiciaries as important contributors to democratic republics. In the United States and abroad, individuals have gained rights to call their governments to account, and to do so often through courts. In parallel fashion, statutory regimes such as the Freedom of Information Act (FOIA) ${ }^{251}$ impose obligations of openness in decisionmaking.

Yet much of the administrative work of the chief justiceship and the federal judiciary's other policymaking bodies have no such obligations. The judiciary has a statutory exemption from both FOIA ${ }^{252}$ and Title VII. ${ }^{253}$ Additionally, as mentioned above, while Congress has mandated

${ }^{250}$ Ronald Dworkin, Presentation, The Secular Papacy, in JUDGES IN CONTEMPORARY DEMOCRACY: AN INTERNATIONAL CONVERSATION 67, 75-77 (Robert Badinter \& Stephen Breyer eds., 2004).

${ }^{251}$ Freedom of Information Act, 5 U.S.C. $\$ \$ 551-557$ (2000).

${ }^{252} I d$. $\$ 551$ (1) (A) \& (B) (exempting the federal courts and Congress from the requirements of FOIA by excluding those two entities from the definition of "agency").

${ }^{253} 42$ U.S.C. \$ $2000 \mathrm{e}$ (b) (2000) (defining employer so as to exempt federal government employees from protection under the statute); see also 29 U.S.C. $§ 630$ (2000) (exempting the United States government from coverage under the Age Discrimination in Employment Act); 42 U.S.C. § 12111(5)(B) (1) (2000) (excluding the U.S. government from coverage by the Americans with Disabilities Act). In 1995 and 1996, Congress enacted laws - the Congressional Accountability Act and the Presidential and Executive Office Accountability Act-overriding the Title VII exemption with respect to the legislative and executive branches by making Title VII and other laws applicable to employees in those branches. See Congressional Accountability Act, Pub. L. No. 1041, § 102, 109 Stat. 3, 5 (1995) (codified at 2 U.S.C. \$ 1302); Presidential and Executive Office Accountability Act, Pub. L. No. 104-331, § 402, 110 Stat. 4053, 4054 (1996) (codified at 3 U.S.C. $\$ 402$ ).

Congress did not pass a similar act with respect to the courts but instead required that the Judicial Conference prepare a report, to be submitted to Congress by the Chief Justice, evaluating the application of Title VII and other laws to judicial employees and recommending any legislation needed to protect judicial branch employees. See $§ 502,109$ Stat. at 41-42. Thereafter, the Judicial Conference stated that it was "wellestablished judiciary policy and practice to follow the equal employment opportunity principles applicable to private sector and government employers." JUDICIAL CONFER- 
openness in rulemaking for the lower courts, the Supreme Court has authority to make its rules without any such obligation. ${ }^{254}$

\section{Representation Undermining Disinterest}

A different kind of democratic failure comes to light when one considers the platform that Chief Justices have erected. Both Chief Justices Burger and Rehnquist often suggested that their various comments represented positions of "the federal judiciary." As a procedural matter, the official mechanism from which positions emerge and become "policy" is the Judicial Conference, which takes formal votes on specific questions.

But how does this group of under thirty know how to vote and speak on behalf of the twelve-hundred-plus Article III judges and the eighthundred-or-so non-life-tenured judges? The majority of the members of the Judicial Conference-the appellate court judges-cannot rely on their selection mechanisms to validate their representation, for they obtain their seats because they are the chief judges of their respective circuits. That position, in turn, derives from a statutory system that gives it to judges who have not yet reached the age of sixty-five but are senior to their other colleagues, in terms of when they were appointed to the bench. ${ }^{255}$ The district court representatives on the Judicial Conference serve for a term, with each circuit setting up its own manner of selection, including some reliance on elections. ${ }^{256}$

ENCE OF THE U.S., STUdY OF JUdicial BRANCH COVERAGE PURSUANT TO THE CONGRESSIONAL ACCOUNTABILITY ACT OF 1995, at 6 (1996). The Conference's report further explained that "[d]ifferences between current judiciary practice and the underlying CAA laws lie mainly in the details of enforcement and dispute resolution," and that " $\mathrm{t}]$ he primary goals of the judiciary in addressing potential changes to current policies are to retain enforcement within the judicial branch structures . . . to avoid unnecessary bureaucracy, and to remain sensitive to legitimate needs of the individual judges and courts." Id. at 15.

Beginning in 1981, before the 1996 legislation, the Administrative Office published an annual Fair Employment Practices Report that included some demographic data about the judiciary's workforce. See, e.g., ADMIN. OfFICE OF THE U.S. COURTS, THE JUdiCIARY FAIR EMPLOYMENT PRACTICES, 25TH ANN. REP. (2005) 1-3 (providing a history of the report); see also Edward M. Chen, The Judiciary, Diversity, and Justice for All, 91 CAL. L. REV. 1109, 1111-13 (2003) (discussing the statistics provided in the 2002 report); ADMIN. OfFICE OF THE U.S. COURTS, ANN. REP. OF THE DIRECTOR 43 (2004) (discussing a new "Fair Employment Practices System," utilized by the AO in the preparation of the Fair Employment Practices report and by the federal courts in the collection and distribution of demographic and employment dispute resolution information).

${ }^{254}$ See supra note 43 and accompanying text.

255 U.S.C. $\$ \S 45(\mathrm{a}), 136$ (a) (2000).

${ }^{256}$ Id. $\$ 331$. 
On specific positions (such as limiting habeas corpus, supporting alternative dispute resolution in lieu of adjudication, or life tenure for bankruptcy judges), the Conference members have not polled the many sitting judges before opining. ${ }^{257}$ Of course, were one to espouse a theory of virtual representation, this system would suffice under the rationale that all judges (trial and appellate, life-tenured and not) are so situated as to hold similar views. ${ }^{258}$ As discussed above, that justification is likely viable on issues such as safety, security, and fair compensation. But the hundreds of federal judges are not likely to subscribe to the same views on matters of constitutional law, statutory interpretation, or democratic process, which are implicated by stances taken by the Judicial Conference about whether access to federal courts should be limited (and for whom) or more decisions should be relegated (or delegated) to non-lifetenured federal judges and to the state courts.

Indeed, the elaboration of principles through adjudication assumes that judges differ. In dialogic exchanges over time, questions are played out through the prism of the facts and relevant law of particular cases; judgments made by small cohorts of judges attentive to nuances shape the law. Dissent has become an important part of these exchanges, ${ }^{259}$ yet norms of administration-expressed recently in the context of the conflict between the $\mathrm{FJC}$ and the $\mathrm{AO}^{260}$-now seek to damp down difference in order to forward judicial "policy" with a single voice.

Move beyond a perspective internal to the judges for whom the Chief Justice and the Conference purport to speak and turn to the constitutional concept of the Article III judiciary, created not to "represent" anything or anyone, but to exercise "the judicial Power of the United

${ }^{257}$ In the era before district judges were permitted to sit on the Judicial Conference, the custom of the Conference was to elicit opinion by polling judges at annual circuit conferences. But after 1957, when each circuit placed one district judge on the Judicial Conference, that practice abated. See Resnik, Trial as Error, supra note 1, at 96465 (discussing debates within the Conference about the Conference's ability to speak to and for federal judges). On occasion, the Federal Judicial Center has conducted surveys. See, e.g., Planning FOR the Future: Results of a 1992 Federal Judicial CENTER SURVEY OF UNITED STATES JUdGES (1994).

${ }^{258}$ This form of representation theory animates rules creating certain kinds of class actions, with the representative being a person from within the class. See John Bronsteen \& Owen Fiss, The Class Action Rule, 78 Notre Dame L. Rev. 1419, 1420 (2003) ("There is no consent and no agency relationship in a class action, and as a consequence interest representation is the only justification for conceiving class actions as representative lawsuits."); Samuel Issacharoff, When Substance Mandates Procedure: Martin v. Wilks and the Rights of Vested Incumbents in Civil Rights Consent Decrees, 77 CORNELL L. REV. 189 (1992).

${ }^{259}$ See Post, supra note 11, at 1274-75.

${ }^{260}$ See supra notes $215-17$ and accompanying text. 
States." Judges are not supposed to have an "interest" as an institutional matter in a particular interpretation of a legal rule, nor are individual judges - whether or not affiliated in the past with political partiessupposed to bring a "party position" to bear. Further, while pressures to democratize the judiciary are sometimes couched in the language of representation, once selected and confirmed, judges are not charged with pressing any point of view. And the better argument for a diverse judiciary is not an essentialist one that all women or men of a particular color or class hold a certain view but rather that, as a matter of equality, the distribution of judgeships ought not to track exclusively one set of demographic characteristics. When the Chief Justice and the Judicial Conference, however, put forth positions on federalism and the allocation of power to non-life-tenured judges and use their powers to shape programmatic agendas for the federal judiciary, they undermine the signature of adjudication as the activity of the disengaged, rendering judgments with no individual and no collective interest to be furthered.

\section{A Creature of Congress and Customs, Not the Constitution}

\section{A. Constitutional Opportunities}

We began by considering how, over the last century, the nature, shape, and work of the federal judiciary has changed, along with the range of persons seen as rightsholders and the obligations of democratic government to exercise its power in an accountable and transparent fashion. We then detailed various forms of authority that have accrued to the Chief Justice and analyzed how, from a range of perspectives, the enlarged repertoire coupled with a life-tenured position as an adjudicator is unwise.

A distinct question is whether, as a matter of constitutional law, such a system is compelled, illicit, or revisable. As is discussed throughout this Symposium, the part of the Constitution devoted to establishing the judicial branch makes no mention of the office of the Chief Justice. ${ }^{261}$ Peter Fish put it well: "[t]he American Constitution envelops the office of Chief Justice with silence." ${ }^{262}$ The one and only constitutional reference

${ }^{261}$ U.S. CONST. art. III. Although the constitutional text is sparse on this subject, many federal statutes advert to the position of the Chief Justice. See, e.g., 28 U.S.C. § 1 (2000) (describing the Supreme Court as comprised of eight Associate Justices and a "Chief Justice of the United States"). That usage began in the First Judiciary Act. See The Judiciary Act of 1789, ch. 20, § 1, 1 Stat. 73, 73 (describing the Supreme Court as consisting of "a chief justice and five associate justices").

${ }^{262}$ Fish, Office of Chief Justice, supra note 3, at 9. 
is found in the discussion of presidential impeachments-Article I specifies that "the Chief Justice shall preside" when a President is tried by the Senate. ${ }^{263}$

Under some schools of constitutional interpretation, textual silence leaves the structure of the chief justiceship wide open, with congressional input possible. Just as Congress has decided the number of Associate Justices serving on the Court and has varied that number over time,${ }^{264}$ so might Congress limit the years a person may serve as Chief Justice or redistribute aspects of the Chief's powers. But other ways to read the Constitution consider the intent of the Framers, precedent, structure, and practices, and, hence, more remains to be explored.

Other contributions focus on the history of what was known about the attitudes of the Constitution's drafters towards the chief justiceship. Given the occasional and largely tangential references to a Chief Justice in the records of the Convention, ${ }^{265}$ and that, according to Professor White, the debates on ratification made no mention of the Chief Justice at all, ${ }^{266}$ not much exists upon which to erect a theory that the current chief justiceship stems from the intent or the original understanding of the Framers.

${ }^{263}$ U.S. CONST. art. I, § 3, cl. 6.

${ }^{264}$ See 1 Stat. at 73; Act of Feb. 24, 1807, ch. 16, $\$ \S 1-5$, 2 Stat. 420 (adding a new circuit court and a sixth Associate Justice); An Act to Amend the Judicial System of the United States, ch. 34, $\S 1,5$ Stat. 176 (1837) (increasing the number of circuits and Justices to nine); Act of Mar. 3, 1863, ch. 100, $\$ 1$, 12 Stat. 794 (adding a tenth circuit and Justice); Act of July 23, 1866, ch. 210, § 1, 14 Stat. 209 (providing that no Associate Justice of the Supreme Court would be replaced until the Supreme Court had only six Associate Justices); Act of Apr. 10, 1869, ch. 22, § 1, 16 Stat. 44 (setting the Court at its current size of nine Justices).

${ }^{265}$ Max Farrand's collection of records from the 1787 convention includes only a few mentions of a Chief Justice. Gouvenour Morris of New York suggested that the Chief Justice be included in the line of succession to the presidency. Others mentioned a Chief Justice as one member of various councils proposed to advise the Executive. See 2 The Records of THE Federal Convention of 1787, at 427 (Max Farrand ed., rev. ed. 1966) (Aug. 27, 1787) (recording Gouverneur Morris's objection to succession of the President by the President of the Senate and proposal that the Chief Justice be named instead); $2 i d$. at 367 (Aug. 22, 1787) (describing a proposed PrivyCouncil to include the Chief Justice, the heads of the Senate and the House of Representatives, and "principal Officer[s]" of government departments, whose duty it would be "to advise [the President] in matters respecting the execution of his Office"); $2 \mathrm{id}$. at 335-37 (Aug. 20, 1787) (describing a Council of State to assist the President in "conducting the Public Affairs" and to include the Chief Justice, expressly charged with "recommend[ing] such alterations of, and additions to, the Laws of the United-States as may in his opinion be necessary to the due administration of Justice, and such as may promote useful learning and inculcate sound morality throughout the Union"). None of these suggestions became a part of the constitutional structure.

${ }^{266}$ White, supra note 11, at 1465. 
That neither the role of the Chief Justice nor its term of office were in focus at the founding is not surprising. Then, the concern was on judges too dependent on the political branches. Only in 1701 had England rejected the practice that judges' commissions ended with that of a given individual's kingship; the Act of Settlement of 1701 created judges' independence from the Crown by providing them with terms of office that could be concluded only through a formal request by the two Houses of Parliament. ${ }^{267}$ Further, when the United States was a fledgling country, its leaders had many opportunities for government service. The job of federal jurist was not necessarily more desirable than other positions. John Jay, for example, left the Supreme Court bench to become Governor of New York. ${ }^{268}$ As Table 1 detailed, more generally during the twenty-year period of 1789 to 1809 , Justices averaged fourteen years of service. In contrast, today's Justices average twenty-four years, bringing to the fore the problem of too long a tenure on the bench for all lifetenured jurists. Yet even as recently as the 1982 Virginia Conference on the chief justiceship, no mention was made of term limits. Today, however, several proposals have been made for such constraints on the Chief Justice as well as for Associate Justices and lower court judges. ${ }^{269}$

Even if lacking much by way of text, consensus at the framing, or implicit structure, but nonetheless still interested in finding constitutional prescriptions as to the length of term, the mode of selection, or the content of the job of the Chief, one could turn to another constitutional interpretative technique-developing premises from an amalgam

${ }^{267}$ See Act of Settlement, 1701, 12 \& 13 W. \& M. 3, c. 2 (Eng.); see also DAVID LEMMINGS, The Independence of the Judiciary in Eighteenth Century England, in THE LIFE OF THE LAW: Proceedings of THE TENTH BRitish Legal History CONFERENCE 125 (Peter Birks ed., 1991) (concluding that, while creating a form of independence in one respect, the Act of Settlement made judges more dependent on parliament as they sought "supplementary places and honours" and, hence, that some politicization of the judiciary resulted); Raoul Berger, Impeachment of Judges and "Good Behavior" Tenure, 79 YALE L.J. 1475, 1478 (1970) (discussing the Act of Settlement).

${ }^{268}$ Felix Frankfurter, Chief Justices I Have Known, 39 VA. L. REv. 883, 884 (1953) (criticizing Jay for leaving).

${ }^{269}$ See Morrison, Opting for Change in Supreme Court Selection, and for the Chief Justice, Too, supra note 41 (proposing a rotating chief justiceship wherein the President would designate the Chief from among the sitting Justices to act as Chief until the expiration of that person's term on the Court, which for all Justices would be limited to eighteen years); Resnik, Democratic Responses, supra note 1, at 197 (discussing term limits for the Chief Justice); Confirmation Hearing on the Nomination of John G. Roberts as Chief Justice of the United States, Before the S. Comm. on the Judiciary, 109th Cong. 535-36 (2005) (statement of Judith Resnik) [hereinafter Resnik Testimony] (suggesting limits and discussing their legality); see also REFORMING THE COURT, supra note 35 (collecting proposals and rationales for limiting the terms of the Justices of the Supreme Court). 
of text and practice. ${ }^{270}$ Article III provides that the "judicial Power of the United States" shall vest in courts with judges holding "their Offices during good Behavior." ${ }^{271}$ The Constitution does not define either the words "hold" or "Offices" or the phrase "during good Behaviour."

Since the country's founding, however, Article III judges have not had either a defined term of office or an age at which retirement is mandatory. Further, since the founding, the practice has been for the President to nominate a Chief Justice and for the Senate to hold a separate confirmation hearing even when an individual (such as Chief Justice Rehnquist $^{272}$ ) has already been confirmed for an associate justiceship. If one reads the prescription that judges hold their offices "during good Behaviour" to require an unfettered run, adds the fact that the nomination of a Chief Justice has been treated as a separate commission, and then invokes concerns that congressional intervention could violate separation-of-powers principles, one could mount an argument that the system currently in place-of an unending term of office for anyone taking the commission of the Chief Justice-is a constitutional requirement. ${ }^{273}$

But competing interpretations are also possible. First, one can argue that the lack of mention of the chief justiceship in the part of the Constitution specifically devoted to the courts gives Congress a range of per-

${ }^{270}$ That approach can be found in Article III case law, which is replete with examples of doctrine tolerating departures from text. The Court has often taken a functionalist approach that sometimes, as Paul Bator argued, verges on the incoherent. See Paul M. Bator, The Constitution as Architecture: Legislative and Administrative Courts Under Article III, 65 IND. L.J. 233 (1990). For example, although Article III appears to commit the "judicial Power of the United States" to judges appointed through Article III processes and protected by Article III attributes, the Court has upheld significant delegations of that power to non-life-tenured jurists (such as bankruptcy and magistrate judges) in courts and in agencies. See, e.g., United States v. Raddatz, 447 U.S. 667 (1980); Commodity Futures Trading Comm'n v. Schor, 478 U.S. 833 (1986); see also Resnik, Inventing the District Courts, supra note 1, at 625-49.

${ }^{271}$ U.S. CONST. art. III, $\S 1$.

${ }^{272}$ Chief Justice Rehnquist was the fifth Chief Justice to be elevated within the Court. His predecessors-Stone, Hughes, Edward D. White, and John Rutledge-all received two commissions, first to be Justice and later Chief Justice of the Supreme Court. Rutledge, a recess appointment, was not confirmed for the chief justiceship and then resigned from the Court.

${ }^{273}$ At the hearings on the nomination of John Roberts, Professor Resnik proposed that Congress impose term limits for chief justiceships. See Resnik Testimony, supra note 269, at 535-36. Professor Charles Fried, who testified on the same panel of law professors, subsequently sent a letter to Senator Arlen Specter, the Chair of the Senate Judiciary Committee, explaining that he thought the suggestion not constitutionally permissible. Letter from Charles Fried, Beneficial Professor of Law, Harvard Law Sch., to Senator Arlen Specter, with copy provided by Professor Fried to Professor Resnik (Sept. 16, 2005) (on file with the University of Pennsylvania Law Review). 
missible constitutional choices for restructuring-so long as the chosen congressional intervention meets the Article III requirements that jurists "hold their Offices during good Behaviour" and does not undermine the capacity of the Court or its Chief Justice to perform essential functions. ${ }^{274}$ Second, one can bracket the administrative portfolio of the Chief Justice and argue that it does not merit Article III protection. Doctrinal support for that analysis comes from the law of judicial immunity, in which the Supreme Court has held that when judges are sued for actions taken as they administer or promulgate rules, they cannot assert the defense of judicial immunity but can only rely on the kind of immunity accorded to officials from other branches discharging analogous functions. ${ }^{275}$

Third, were one tempted to claim that Article III commissions run exclusively to one particular office, that approach would render constitutionally suspect congressional statutes, extant since 1922, authorizing the Chief Justice to license judges to "sit by designation" in districts and circuits other than those to which they had been appointed as well as to appoint some judges to specialized tribunals. Further put into question would be innovations of the second half of the twentieth century, when Congress set term limits for the chief judgeships of the lower courts. ${ }^{276}$ In short, a good deal of practical evidence supports an understanding that Congress can define different charters for sitting jurists without undermining the constitutional guarantees of Article III.

Another potential hurdle for enthusiasts of term limits for the Chief Justice is the meaning of Article III's protection of service during "good Behaviour." That phrase has been of interest on various occasions, such as when members of Congress have sought to impeach a judge or to create sanctions short of impeachment. ${ }^{277}$ For example, when members of

${ }^{274}$ The "essential function" theory of Article III is associated with several academics, including Henry Hart, Jr., The Power of Congress to Limit the Jurisdiction of Federal Courts: An Exercise in Dialectic, 66 HARV. L. REV. 1362 (1953); Leonard G. Ratner, Congressional Power Over the Appellate Jurisdiction of the Supreme Court, 109 U. PA. L. REV. 157 (1960); and Theodore Eisenberg, Congressional Authority to Restrict Lower Federal Court Jurisdiction, 83 YALE L.J. 498 (1974).

${ }^{275}$ See Supreme Court of Va. v. Consumers Union of the U.S., 446 U.S. 719, 731-34 (1980) (holding that, when the Virginia Supreme Court promulgated and administered disciplinary rules, that Court was not entitled to "judicial" immunity but rather, under a functional analysis, the forms of immunity accorded to either legislators or executive branch members).

${ }^{276}$ See 28 U.S.C. $\S 45(3)$ (A) (2000) (limiting the term of chief judges of circuit courts to seven years); id. $\S 136$ (3) (A) (limiting the term of chief judges of district courts to seven years).

${ }^{277}$ For example, in support of his argument that Congress has the power to define a breach of "good Behaviour" to include more than a "high crime and misdemeanor," Professor Raoul Berger noted that the phrase "hold[ing] their Offices during good Behav- 
Congress considered the problems of disabled or poorly functioning judges, the question emerged: did the guarantee of service during "good Behaviour" preclude Congress from doing anything other than impeachment to stop judges from working in ways harmful to the administration of justice? ${ }^{278}$ The answer has repeatedly been that it does not, as Congress has provided for certifications of disability ${ }^{279}$ as well as enacted the Judicial Councils Reform and Judicial Conduct and Disability Act of $1980,{ }^{280}$ which includes a range of sanctions administered by the judiciary. Congress there authorized the judiciary to ask a judge to retire voluntarily or to certify that jurist's disability yet not order "removal from office." stitutionality, ${ }^{282}$ with courts distinguishing ending the service of a judge from that judge's "removal from office." These statutory examples support the proposition that the chief justiceship could be a term-limited job without breaching Article III's "hold office" in "good behaviour" provisions.

Additional support comes from congressional legislation (mentioned earlier) imposing term limits on the lower courts' chief judges.

iour" dated from the 1701 Act of Settlement, which protected judges "so long as they conduct[ed] themselves well," while also creating procedural requirements to limit their terms of service. See Berger, supra note 267, at 1478, 1530; see also id. at 1500-01 (discussing further the Act of Settlement); Burke Shartel, Federal Judges-Appointment, Supervision, and Removal-Some Possibilities Under the Constitution, 28 MICH. L. REV. 870 (1930); Note, Removal of Federal Judges: A Proposed Plan, 31 ILL. L. REv. 631, 636-39 (1937).

${ }^{278}$ See RusSELl R. WHEELER \& A. LEO LEVIN, JudiCIAL DISCIPLINE AND REMOVAL IN THE UNITED STATES 49-54 (1979); see generally REPORT OF THE NATIONAL COMMISSION ON JUDicial Discipline \& REMOVAL 17-32 (1993); Stephen B. Burbank, The Architecture of Judicial Independence, 72 S. CAL. L. REV. 315, 340, 346-48 (1999); Richard L. Marcus, Who Should Discipline Federal Judges, and How?, 149 F.R.D. 375 (1993).

${ }^{279}$ Enacted in 1957, 28 U.S.C. $\$ 372$ (b) authorizes circuit Judicial Councils to certify judges as disabled, thereby allowing the President to appoint an additional judge to serve on the circuit in addition to the disabled judge. Act of Sept. 2, 1957, Pub. L. No. 85-261, 71 Stat. 586. The Chief Justice bears responsibility under this statute for certifying the disability of the Chief Judge of the Court of International Trade. 28 U.S.C. $\S$ 372(b). Statutes allowing certain judges to relieve disabled judges of their duties (but not their Article III commissions) date back as far as 1801. For a historical overview of these statutes, see Charles Gardner Geyh, Informal Methods of Judicial Discipline, 142 U. PA. L. REV. 243, 271-76 (1993).

${ }^{280}$ Pub. L. No. 96-458, 94 Stat. 2035 (codified as amended in scattered sections of 28 U.S.C., including $\$ \S 351,372$ ); see generally Marcus, supra note 278 (assessing the costs and benefits of judicial discipline under the Act); Stephen B. Burbank, Procedural Rulemaking Under the Judicial Councils Reform and Judicial Conduct and Disability Act of 1980, 131 U. PA. L. REV. 283 (1982).

${ }^{281} 28$ U.S.C. $\$ 354$ (a) (3) (A) (2000 \& Supp. II 2002).

282 See, e.g., McBryde v. Comm. to Review Circuit Council Conduct and Disability Orders of the Judicial Conference of the U.S., 264 F.3d 52, 64-69 (D.C. Cir. 2001) (rejecting Article III and separation of powers challenges to the Act). 
During the 1950s, Congress provided age limits for the chief judges of the lower federal courts. ${ }^{283}$ That innovation occasioned relatively little debate. Proponents explained simply that constitutionality remained intact because a "distinction [was] made between the judge in his judicial capacity and in his administrative capacity;" and the statute proposed only to take away administrative tasks. ${ }^{284}$ In short, the federal system could (as several academics now propose) ${ }^{285}$ meet its obligation to insulate jurists in general from retribution by having a fixed endpoint to their service ${ }^{286}$ and could do so specifically for the Chief Justice of the United States. ${ }^{287}$

Thus, a better reading of the Article III requirements is that, so long as a person retains the office of a federal judge with salary protected, both reassignment from one particular post to another and divestiture of administrative responsibilities are permissible. Moreover, given the absence of a mention of the chief justiceship in Article III, no special rule about "holding office" attaches to that post. Therefore, the Constitution would permit a rotating chief justiceship similar to that of some state $\operatorname{courts}^{288}$ and of the lower federal courts, ${ }^{289}$ with the position of chief justice moving by seniority or some other system.

Two constitutional caveats are required. Article I requires the Chief Justice to preside at impeachment trials of the President. A statute fixing term limits for the chief justiceship would have to provide for that

283 See supra note 276 and accompanying text.

${ }^{284}$ S. REP. NO. 85-1780 (1958), as reprinted in 1958 U.S.C.C.A.N. 3526, 3528.

${ }^{285}$ See, e.g., Steven G. Calabresi \& James Lindgren, Term Limits for the Supreme Court: Life Tenure Reconsidered, in REFORMING THE COURT, supra note 35, at 15. But see Stephen B. Burbank, Alternative Career Resolution II: Changing the Tenure of Supreme Court Justices, 154 U. PA. L. REV. 1511 (2006).

${ }^{286}$ See Resnik, Democratic Responses, supra note 1, at 182 (identifying the United States as anomalous in not imposing term limits).

${ }^{287}$ See id. at 181-201.

${ }^{288}$ Several state constitutions provide for rotation of the chief justiceship, creating a term for that office that is shorter than the general term of service as a justice on the court. See, e.g., ALASKA CONST. art. 4, § 2(b) (providing that the members of the Alaska Supreme Court shall select a new chief justice every three years); IDAHO CONST. art. V, $\S 6$ (providing that the justices of the Idaho Supreme Court shall serve six-year terms but that the chief justice shall be selected by the other justices of the supreme court to hold office for a term of four years); WASH. CONST. art. $4, \S 3$ (providing that the Washington Supreme Court judges, who serve seven-year terms, shall select a chief justice from among them to serve a four-year term). The state of Colorado authorizes its supreme court to select one of its members to serve as chief justice "at the pleasure of a majority of the court." ColO. ConsT. art. VI, $\S 5$. For a complete overview of states' methods of selecting chief justices and states' designated terms for the position, see infra Appendix C, Tenure and Methods of Selection of State Chief Justices.

${ }^{289}$ See supra note 255 and accompanying text. 
unlikely contingency by including automatic extensions of a Chief Justice's term if an impeachment trial were underway. Further, Article III protects against the diminution of judicial salaries and, currently, the Chief Justice receives a small increment in compensation over that paid to Associate Justices. ${ }^{290}$ To avoid violating the non-diminution mandate, the salaries of all Justices could be equalized or the person who serves as Chief could continue to receive that modest premium after ceasing to hold that special post.

Another constitutional question would then need to be addressedhow to select successor Chief Justices. Could Associate Justices select the Chief Justice (as in some state systems ${ }^{291}$ ), or does that proposition violate the Appointments Clause, with its mandate to the President to appoint "Judges of the supreme Court?" ${ }^{292}$ Once again, constitutional silence (no mention of a special appointment or designation process for the Chief Justice) makes difficult the claim of a constitutional breach, so long as the President has nominated the person to the Supreme Court. Further, given the tradition of inherent judicial powers and statutes that authorize self-governance of the judiciary, ${ }^{293}$ selection from within by other jurists could be seen as supportive of the independence of the Supreme Court.

That Congress could constitutionally alter the term of the Chief Justice does not mean that either the President or the Congress could shape the job in a way that undercuts the Court's capacity to work. The more general rubric of separation of powers requires the preservation of the Supreme Court specifically (and of the federal courts more generally) as a coordinate branch of government, not to be micromanaged by Congress, which could, through thousands of small cuts, immobilize the federal judicial system. Were Congress, for example, to require that the chief justiceship change for each case or each month, such a statute would be unconstitutional. ${ }^{294}$ Similarly, if either the President or the

${ }^{290}$ For 2006 , the Chief Justice is to be paid $\$ 212,100$, while Associate Justices are to be paid $\$ 203,000$. Exec. Order No. 13,393, 70 Fed. Reg. 76,655, 76,660 (Dec. 22, 2005).

${ }^{291}$ See infra Appendix C, Tenure and Methods of Selection of State Chief Justices.

${ }^{292}$ U.S. CONST. art. II, § 2, cl. 2.

293 See, e.g., Pub. L. No. 96-458, 94 Stat. 2035.

${ }^{294}$ See, e.g., Starrs v. Ruxton, 2000 J.C. 208 (H.J.C. 1999) (Scot.) (relying on Article 6(1) of the European Convention on Human Rights and Fundamental Freedoms to conclude that too short a term of office is a violation of the right to "an independent and impartial tribunal," as a judge in such a position "might be influenced by his hopes and fears as to his prospective advancement"). Some Canadian cases address a comparable concern. See, e.g., Reference re Territorial Court Act (N.W.T.) s.6(2) [1997], 152 D.L.R. (4th) 132 (N.W.T.). 
Congress were to reappoint Chief Justices at brief intervals, or the President were to use every opening to put a new person in the chief justiceship, the ability of the Court to function would be disrupted.

In contrast, if the person who served in the position of the Chief Justice did so for seven years (to parallel the length of service described in the statutes addressing the chief judges of the district and appellate courts), and afterwards retained the status of a federal judge or Justice, that person's tenure would be protected but that person's power cabined. Such a rule would also enable an orderly succession of service that in turn has administrative advantages.

\section{B. Statutory Innovations and Occasions for Self-Restraint}

Given the constitutional possibilities, we turn then to whether Congress should act. Because the chief justiceship as we have come to know it is, in large measure, a creature of Congress rather than the Constitution, congressional restructuring seems particularly appropriate to constrain the entrenchment of power and the disproportionate impact that one individual can have on American law through unduly long terms. ${ }^{295}$ Action is appropriate despite the allure, for some, of strong executive power. Term limits and reduced statutory powers-sketched belowwould not prevent a Chief Justice from continuing to be a visible and

\footnotetext{
${ }^{295}$ At a few points in the last decades, proposals to constrain some of the functions of the Chief Justice or the Court have been made. For example, in 1986, the ABA Standing Committee on Federal Judicial Improvements urged creation of an office of "chancellor" to identify an individual designated as the head of the judicial system and to relieve the Chief of administrative duties other than those related to the Supreme Court. See Letter from Daniel Meador to Hon. Joseph F. Weis (May 8, 1989) reprinted in REPORT OF THE SUbCOMMITTEE ON ADMINISTRATION, MANAGEMENT, AND STRUCTURE,

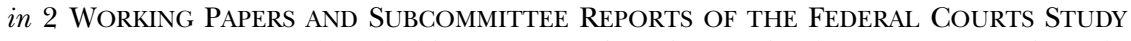
COMMITTEE Part IV.K. (1990) (discussing and enclosing the 1986 recommendation). The congressionally created Federal Courts Study Committee, described supra notes 83 and 120, acknowledged the ABA proposal for a "chancellor" but deferred to Chief Justice Rehnquist's suggestion that the issue of reconfiguration be assigned to a Judicial Conference committee. See Report of the Federal Courts Study CommitTee, supra note 83, at 145-46. The Federal Courts Study Committee recommended that "very careful and extended consideration by knowledgeable persons under the aegis of the Chief Justice" be given to the "chancellor" proposal, but that whatever conclusion is reached, the Chief Justice should remain "the acknowledged head of the entire federal judiciary." Id. at 146.

In 1995, the Judicial Conference's Long Range Plan concluded that an additional administrative post was unnecessary. The Long Range Plan recommended that " $[t]$ he Chief Justice of the United States should remain the head of the federal judicial system, retaining the traditional authority and responsibility of that office in matters of judicial administration.” See LONG RANGE PLAN, supra note 120, at 77, 166 F.R.D. at 137 (detailing Recommendation 41); see also Wheeler, Chief Justice Rehnquist, supra note 141, at 120 (discussing the proposal for a chancellorship).
} 
important spokesperson for a set of issues, such as judicial independence, when the need arises.

To explore how to alter the length of tenure, discussion of more of the history of term positions for the chief judges of the lower courts is useful, as is some understanding of current economic incentives to serve long terms. The interest in limiting the tenure of chief judges of the lower courts came from within-in light of concerns that some individuals holding the position of chief judge were either inept administrators or too old to handle the workload. In 1956, a committee of the Judicial Conference of the United States commissioned a survey of chief judges; learned was that the average age of circuit chief judges was about seventy-two. Chief judges of the district courts were somewhat younger, averaging about sixty-five years of age. The terms of office for both groups averaged about eight-and-a-half years. ${ }^{296}$

The Conference concluded that, while many judges of older years did "excellent work," the "toll of years has a tendency to diminish celerity, promptitude, and effectiveness." ${ }^{297}$ These concerns reflect what has come to be standard advice for other organizations-that ensuring regular turnover in leadership enables an institution to revitalize its practices. The Conference proposed that Congress enact legislation to "relieve chief judges of the circuit and district courts from their administrative duties upon reaching the age of seventy-five, so that they may devote their entire time to the law work of the courts and not to the administrative details." ${ }^{298}$ With support from the Department of Justice and the Judiciary, an age limit—set at seventy—became law. ${ }^{299}$

In the 1970s, in a report from a Commission on Revision of the Federal Court Appellate System, the issue was revisited. Noted were the problems with a straight seniority system, including that no account was taken of the abilities of an individual for administration. ${ }^{300}$ Rejecting election by one's peers as politicizing the decision, the Commission recommended that a chief judge serve a single term of a maximum of seven years. The results can be found in statutes providing that, upon a va-

${ }^{296}$ S. REP. NO. 85-1780 (1958), as reprinted in 1958 U.S.C.C.A.N. 3526, 3527.

${ }^{297} I d$. at 3528. More recent commentary on the difficulties that age imposes for Supreme Court Justices and the role played by older Justices includes David J. Garrow, Mental Decrepitude on the U.S. Supreme Court: The Historical Case for a 28th Amendment, 67 U. CHI. L. REV. 995 (2000); and Epstein, Knight \& Shvetsova, supra note 242, at 25-27.

${ }^{298}$ S. REP. NO. 85-1780, supra note 296, at 3526.

${ }^{299}$ See Act of Aug. 6, 1958, Pub. L. No. 85-593, 72 Stat. 497 (codified as amended at 28 U.S.C. $\$ \S 45(3)(\mathrm{C}), 136(3)(\mathrm{C})(2000))$.

${ }^{300}$ Commission on the Revision of the Federal Court Appellate System: Structure and Internal Procedures: Recommendations for Change, 67 F.R.D. 195, 274-75 (1975). 
cancy, chief judges of both trial and appellate courts are to be those persons "senior in commission" who are sixty-four or under, have served for one or more years as a judge, and have not previously been the chief judge; such persons then have an opportunity to serve a seven-year term as chief. ${ }^{301}$

An alternative to a mandatory length of service is to create economic incentives to prompt the Chief Justice to relinquish the post. As the table contrasting different average lengths that justices and judges have served over the last two centuries indicates, ${ }^{302}$ federal judges now serve, on average, about twenty-four years. While many factors have helped to produce the growth in the length of service of life-tenured judges, ${ }^{303}$ a key variable is the pension system which, as currently configured by Congress, creates economic incentives for judges to stay on the bench. ${ }^{304}$ Specifically, when Article III judges or Justices retire by taking "senior status," they open up a judgeship slot (allotted by statute) for the courts on which they serve. ${ }^{305}$ But they need not resign in order to take a form of retirement that permits a new appointment to be made. Moreover, the current structure makes continuing to work economically attractive. Thus, many retirees on the lower courts continue to sit as judges, and, as Professor Albert Yoon has detailed, ${ }^{306}$ still shoulder a significant amount of judicial work. ${ }^{307}$

Congress could use its pension system differently by providing significantly better pension benefits with special bonuses to Chief Justices who serve for no longer than a set period. Economic models could assist

${ }^{301}$ See Stephen L. Wasby, The Work of a Circuit's Chief Judge, 24 JUST. SYS. J. 63, 66 (2003) (discussing examples in which individuals stepped aside before their seven-year term ended to enable others, who would have missed the opportunity because they would have become sixty-five, to serve as chief judge); see also supra note 276.

${ }^{302}$ See supra Table 1, Lengths of Service of Article III Judges: Contrasting Snapshots, 1800 s/2000s.

${ }^{303}$ See Albert Yoon, The End of the Rainbow: Understanding Turnover Among Federal Judges 13-14, available at http://www.irs.princeton.edu/seminars/yoon.pdf (last visited May 7, 2006) (unpublished manuscript). Further, in recent decades, selection processes have focused on judges serving at a lower court as a pool from which to draw jurists for higher courts. Relying on a career ladder for appointing judges produces jurists with more total years in the judiciary. Whether being a federal judge correlates with longevity is another possibility.

${ }^{304}$ See id. at $31-32$.

${ }^{305} 28$ U.S.C. $\$ 371(\mathrm{~d})$ (2000) (providing that the President shall appoint a successor to the retiring judge or Justice).

${ }^{306}$ See Albert Yoon, As You Like It: Senior Federal Judges and the Political Economy of Judicial Tenure, 2 J. OF EMPIRICAL LEGAL STUD. 495, 499 (2005).

${ }^{307}$ See id. at 495, 515, 522 (estimating that senior judges comprise thirty-seven percent of all sitting Article III judges and that, on average, a senior district court judge carries sixty-three percent of the caseload of an active district court judge). 
in fashioning an optimal intervention, similar to some universities' packages of benefits and salary that have prompted tenured professors to take early retirement. Yet for persons of significant or sufficient independent means, monetary rewards are less enticing, making an incentive system operate differently depending upon an individual's wealth or that of the person's household. A more direct and helpful intervention would thus be to impose statutory limits. As for the constitutional question of whether such a provision could apply to a sitting Chief Justice, prospective application would avoid the issue. And, the Chief Justice then in office could choose whether to set a voluntary example by following the new regime.

Turning from the length of the term to the scope of the powers, Congress is the body that endowed the Chief Justice with the task of presiding at the Judicial Conference and the power to assign sitting judges to special courts. Thus, the legislature can-and shouldrevisit these grants of power. The idea of restructuring the tasks assigned to the Chief Justice is not new; proposals have surfaced periodically for a "Chancellor" or other officer freed from oversight by the Chief Justice but accountable to the Judicial Conference. ${ }^{308}$ Similarly, an inter-branch commission has been suggested to focus on the needs of the judiciary. ${ }^{309}$

One way to begin the process of revision is to review the statutes giving powers to the Chief Justice, which are set forth in Appendix B, and which are listed to be comprehensive rather than classified by impact. The Chief Justice need not be the jurist assigned to chair the Judicial Conference or to pick the members of its committees. Alternatives include requiring that the chair rotate among judges who serve on the Conference or that members of the Conference select their own chair, again for a specified and limited term. Congress should

${ }^{308}$ See, e.g., Meador, The Federal Judiciary and Its Future Administration, supra note 205, at 1047-53 (proposing both the creation of a position of a high-level assistant (to be filled by a person already serving as an Article III judge) to aid the Chief Justice and the creation of a new and relatively independent administrative position held by a person not under the supervision of the Chief Justice); Wheeler, Chief Justice Rehnquist, supra note 141, at 120 (discussing such proposals). Chief Justice Burger discussed the creation of an office of Circuit Justice for Administration (to be filled by a federal judge with trial and appellate experience) but did not elaborate the content of a portfolio for the proposed position. See Burger, Address at the American Enterprise Institute, supra note 206, at 1047; see generally RUSSELL R. WHEELER \& GORDON BERMANT, Federal Court Governance: Why Congress Should-ANd Why CONGRess Should Not-Create a Full-Time Executive Judge, Abolish the Judicial CoNFERENCE, AND REMOVE CirCuIT JUdGES From District COURT GOVERNANCE (Fed. Jud. Ctr. 1994).

${ }^{309}$ See Geyh, supra note 218, at 1234-41. 
also revisit how specialty courts are created. Appointments to courts such as the Foreign Intelligence Surveillance Act Court could be through mechanisms like random selection from various circuits rather than by the Chief Justice.

As for the Chief Justice's power to appoint lower court judges to special courts and to select senior executives, that power is not without its problems, for appointments can provide opportunities for patronage. Yet Congress has and can continue to "vest the Appointment" of "inferior Officers" in the "Courts of Law," Chief Justice the power to appoint various court officials. But Congress ought to explore alternatives not only for special tribunals but also for two senior positions, the Director of the AO and the Director of the FJC, both of which could either be subject to confirmation, as are many other senior executive positions in the federal government, or be chosen by committees or commissions operating independently of the Chief Justice. The Administrative Assistant, in contrast, working directly and closely with the Chief Justice, ought to remain a person selected by the Chief Justice.

Change need not come only from Congress. Just as Chief Justices have in the past been the source of so many aspects of the current job, so could the new and future Chief Justices affect expectations and reshape customs. The new Chief Justice could alter practices either by sharing the work within or by going to Congress to seek revision of some of the statutory charters that run to that office. Some evidence of interest in broadening participation has come in the months since Chief Justice Roberts was appointed. After the resignation of Ralph Mecham, the most recent Director of the AO who long served Chief Justice Rehnquist, the Chief Justice appointed a committee of several

${ }^{310}$ U.S. CONST. art. II, § 2, cl. 2; see Freytag v. Comm'r, 501 U.S. 868, 883, 888-92 (1991) (construing "Courts of Law" to include the legislatively created Tax Court and rejecting petitioners' challenge to legislation that authorized the Chief Judge of the Tax Court to appoint special trial judges within that court). Justice Scalia, joined by Justices O'Connor, Kennedy, and Souter, concurred in part, but Justice Scalia objected to the conclusion that the Tax Court was a "Court"-opining that the Tax Court was a "'Departmen[t]' and the Chief Judge [was] its head." Id. at 901 (Scalia, J., concurring). The majority agreed that the appointment power had been designed to "ensure that those who wielded it were accountable to public force and the will of the people," and stressed that the "power of appointment to offices" was, at the time of the founding, understood as a serious source of "despotism." Id. at 884 (majority opinion) (quoting, as the source of the term "despotism," GORDON WOOD, THE CREATION OF THE AMERICAN REPUBLIC 1776-1787 at 79 (1969)); see also id. at 904-06 (Scalia, J., concurring) (emphasizing that the appointment power was originally understood as a source of patronage). 
judges to advise him on the replacement. ${ }^{311}$ That collaborative effort could be the beginning of other similar decisions as the new Chief Justice puts his stamp on the office.

Corporate theorists might not expect a leader with such an unstructured and generous grant of power to relinquish any of it voluntarily. The burden of this contribution, however, is to make plain the need for the federal judiciary to be as peculiar a bureaucracy as possible, regularly violating Weberian expectations of organizational behavior because of judges' deeper commitments to the task of adjudication. The judiciary wants to be free of micromanagement by other branches and able to decide a host of internal matters as it provides its specialized services of adjudication. But the judiciary can properly invoke judicial independence as a justification for its freedom only if it does not act like an ordinary agency pursuing programmatic ends. Chief Justices of recent eras have made that more difficult, but this rare occasion-a new Chief Justice-could mark a moment of change and, by doing so, make such moments less unusual in the future.

${ }^{311}$ See Steve Lash, Top Judge Seeks Top Administrator, CHIC. DAILY L. Bull., Dec. 16, 2005, at 1 (noting that the Chief Justice had created a committee, chaired by the Honorable Michael Boudin of the First Circuit, to help review applications for the new Director of the AO). 


\section{APPENDIX A}

Tenure of Chief Justices of the United States, of Directors of the Administrative Office of the U.S. Courts, and of Directors of the Federal Judicial Center

\begin{tabular}{lll} 
Name of Chief Justice & Term Began & Term Completed \\
\hline \hline John Jay & October 19, 1789 & June 29, 1795 \\
\hline John Rutledge & August 12, 1795 & December 15, 1795 \\
\hline Oliver Ellsworth & March 8, 1796 & December 15, 1800 \\
\hline John Marshall & February 4, 1801 & July 6, 1835 \\
\hline Roger Brooke Taney & March 28, 1836 & October 12, 1864 \\
\hline Salmon Portland Chase & December 15, 1864 & May 7, 1873 \\
\hline Morrison Remick Waite & March 4, 1874 & March 23, 1888 \\
\hline Melville Weston Fuller & October 8, 1888 & July 4, 1910 \\
\hline Edward Douglass White & December 19, 1910 & May 19, 1921 \\
\hline William Howard Taft & July 11, 1921 & February 3, 1930 \\
\hline Charles Evans Hughes & February 24, 1930 & July 1, 1941 \\
\hline Harlan Fiske Stone & July 3, 1941 & April 22, 1946 \\
\hline Fred Moore Vinson & June 24, 1946 & September 8, 1953 \\
\hline Earl Warren & October 5, 1953 & June 23, 1969 \\
\hline Warren Earl Burger & June 23, 1969 & September 26, 1986 \\
\hline William Hubbs Rehnquist & September 26, 1986 & September 3, 2005 \\
\hline John Glover Roberts, Jr. & September 29, 2005 & \\
\hline
\end{tabular}




\begin{tabular}{llll} 
Name of AO Director & $\begin{array}{l}\text { Term } \\
\text { Began }\end{array}$ & $\begin{array}{l}\text { Term } \\
\text { Completed }\end{array}$ & $\begin{array}{l}\text { Service Under } \\
\text { Chief Justice(s) }\end{array}$ \\
\hline \hline Henry P. Chandler & 1939 & 1956 & $\begin{array}{l}\text { Hughes, Stone, } \\
\text { Vinson, Warren }\end{array}$ \\
\hline Warren Olney III & 1958 & 1967 & Warren \\
\hline Ernest C. Friesen & 1968 & 1970 & Warren, Burger \\
\hline Rowland F. Kirks & 1970 & 1977 & Burger \\
\hline William E. Foley & 1977 & 1985 & Burger \\
\hline Leonidas Ralph Mecham & 1985 & 2006 & $\begin{array}{l}\text { Burger, Rehnquist, } \\
\text { Roberts }\end{array}$ \\
\hline James C. Duff & & & Roberts \\
\hline
\end{tabular}

\begin{tabular}{llll} 
Name of FJC Director & $\begin{array}{l}\text { Term } \\
\text { Began }\end{array}$ & $\begin{array}{l}\text { Term } \\
\text { Completed }\end{array}$ & $\begin{array}{l}\text { Service under } \\
\text { Chief Justice(s) }\end{array}$ \\
\hline \hline Hon. Tom C. Clark & 1968 & 1970 & Warren, Burger \\
\hline Hon. Alfred P. Murrah & 1970 & 1974 & Burger \\
\hline Hon. Walter E. Hoffman & 1974 & 1977 & Burger \\
\hline A. Leo Levin & 1977 & 1987 & Burger, Rehnquist \\
\hline Hon. John C. Godbold & 1987 & 1990 & Rehnquist \\
\hline Hon. William W Schwarzer & 1990 & 1995 & Rehnquist \\
\hline Hon. Rya W. Zobel & 1995 & 1999 & Rehnquist \\
\hline Hon. Fern M. Smith & 1999 & 2003 & Rehnquist \\
\hline Hon. Barbara Jacobs Rothstein & 2003 & & Rehnquist, Roberts \\
\hline
\end{tabular}




\section{APPENDIX B}

\section{Statutory Duties of the Chief Justice of the United States}

\begin{tabular}{|c|c|}
\hline 2 U.S.C. $\$ 135$ & $\begin{array}{l}\text { The Librarian of Congress purchases law books under the } \\
\text { direction of the Chief Justice. }\end{array}$ \\
\hline 2 U.S.C. $\$ 352$ & $\begin{array}{l}\text { The Chief Justice appoints two of the eleven members of the } \\
\text { Citizens' Commission on Public Service and Compensation. }\end{array}$ \\
\hline 5 U.S.C. $\$ 5520 \mathrm{a}$ & $\begin{array}{l}\text { The Chief Justice or the Chief Justice's designee is responsible } \\
\text { for promulgating regulations to implement garnishment of } \\
\text { pay provisions for the judicial branch. }\end{array}$ \\
\hline 5 U.S.C. $\$ 5582$ & $\begin{array}{l}\text { The Chief Justice or the Chief Justice's designee is responsible } \\
\text { for promulgating regulations allowing judicial branch em- } \\
\text { ployees to designate beneficiaries. }\end{array}$ \\
\hline 8 U.S.C. $\$ 1532$ & $\begin{array}{l}\text { The Chief Justice appoints the five district judges who consti- } \\
\text { tute the Alien Terrorist Removal Court. }\end{array}$ \\
\hline 8 U.S.C. $\$ 1532$ & $\begin{array}{l}\text { The Chief Justice designates the chief judge of the Alien Ter- } \\
\text { rorist Removal Court from among the members of that court. }\end{array}$ \\
\hline 10 U.S.C. $\$ 942$ & $\begin{array}{l}\text { If a vacancy occurs on the U.S. Court of Appeals for the } \\
\text { Armed Forces, the Chief Justice may, upon the chief judge of } \\
\text { that court's request, appoint an Article III judge to fill the } \\
\text { vacancy. }\end{array}$ \\
\hline $\begin{array}{l}18 \text { U.S.C. } \\
\text { app. } 3, \S 9\end{array}$ & $\begin{array}{l}\text { The Chief Justice prescribes rules to protect against disclosure } \\
\text { of classified information held by the federal courts. }\end{array}$ \\
\hline 19 U.S.C. $\$ 3432$ & $\begin{array}{l}\text { The Chief Justice approves judges who have been identified by } \\
\text { circuit chief judges as eligible to participate on NAFTA dis- } \\
\text { pute settlement panels and submits a list of approved judges } \\
\text { to the Trade Representative. }\end{array}$ \\
\hline 20 U.S.C. $\$ 41$ & $\begin{array}{l}\text { The Chief Justice, the President, the Vice President, and the } \\
\text { heads of executive departments constitute the Smithsonian } \\
\text { Institution. }\end{array}$ \\
\hline 20 U.S.C. $\S 42$ & $\begin{array}{l}\text { The Board of Regents of the Smithsonian Institution is com- } \\
\text { posed of the Chief Justice, the Vice President, three Members } \\
\text { of the Senate, three Members of the House of Representa- } \\
\text { tives, and nine other persons who are not Members of Con- } \\
\text { gress. }\end{array}$ \\
\hline 20 U.S.C. $\$ 72$ & $\begin{array}{l}\text { The Board of Trustees of the National Gallery of Art includes } \\
\text { the Chief Justice, the Secretary of State, the Secretary of the } \\
\text { Treasury, the Secretary of the Smithsonian Institution, ex offi- } \\
\text { cio, and five general trustees. }\end{array}$ \\
\hline 20 U.S.C. $\$ 76 c c$ & $\begin{array}{l}\text { The Board of Trustees of the Hirshhorn Museum and Sculp- } \\
\text { ture Garden includes the Chief Justice and the Secretary of } \\
\text { the Smithsonian Institution, who serve as ex officio members, } \\
\text { and eight general members. }\end{array}$ \\
\hline 20 U.S.C. $\$ 4502$ & $\begin{array}{l}\text { The Chief Justice recommends two members of the judiciary } \\
\text { to serve on the James Madison Memorial Fellowship Founda- } \\
\text { tion Board of Trustees. }\end{array}$ \\
\hline
\end{tabular}




\begin{tabular}{|c|c|}
\hline 28 U.S.C. $\$ 1$ & $\begin{array}{l}\text { The Supreme Court of the United States consists of a Chief } \\
\text { Justice of the United States and eight Associate Justices, any } \\
\text { six of whom constitute a quorum. }\end{array}$ \\
\hline 28 U.S.C. $\$ 42$ & $\begin{array}{l}\text { The Chief Justice may allot the Justices among the circuits if } \\
\text { such allotment is necessary while the Court is in vacation. }\end{array}$ \\
\hline 28 U.S.C. $\$ 45$ & $\begin{array}{l}\text { The Chief Justice receives the certification of a circuit court } \\
\text { chief judge who decides to step down and to resume service as } \\
\text { a circuit judge. }\end{array}$ \\
\hline 28 U.S.C. $\$ 49^{*}$ & $\begin{array}{l}\text { The Chief Justice appoints three Justices or circuit judges to } \\
\text { compose a body, called the Special Division of the U.S. Court } \\
\text { of Appeals for the District of Columbia, to appoint independ- } \\
\text { ent counsels. }\end{array}$ \\
\hline 28 U.S.C. $§ 136$ & $\begin{array}{l}\text { The Chief Justice receives the certification of a district court } \\
\text { chief judge who decides to step down and to resume service as } \\
\text { a district judge. }\end{array}$ \\
\hline 28 U.S.C. $§ 258$ & $\begin{array}{l}\text { The Chief Justice receives the certification of a Court of In- } \\
\text { ternational Trade chief judge who decides to step down and } \\
\text { to resume service as a judge on that court. }\end{array}$ \\
\hline 28 U.S.C. § 291 & $\begin{array}{l}\text { Upon request of the chief judge or circuit justice of that cir- } \\
\text { cuit, the Chief Justice may temporarily assign a circuit judge to } \\
\text { another circuit. }\end{array}$ \\
\hline 28 U.S.C. $§ 292$ & $\begin{array}{l}\text { Upon presentation of a certificate of necessity by the chief } \\
\text { judge or circuit justice of that circuit, the Chief Justice may } \\
\text { temporarily assign a district judge to another circuit. }\end{array}$ \\
\hline 28 U.S.C. $§ 292$ & $\begin{array}{l}\text { Upon presentation of a certificate of necessity by the chief } \\
\text { judge of that court, the Chief Justice may temporarily assign a } \\
\text { district judge to the Court of International Trade. }\end{array}$ \\
\hline 28 U.S.C. $§ 293$ & $\begin{array}{l}\text { Upon presentation of a certificate of necessity by the chief } \\
\text { judge of that circuit, the Chief Justice may temporarily assign } \\
\text { a judge from the Court of International Trade to serve in any } \\
\text { circuit. }\end{array}$ \\
\hline 28 U.S.C. $§ 294$ & $\begin{array}{l}\text { The Chief Justice may designate a retired Justice to serve as a } \\
\text { judge or circuit justice on a court of appeals. }\end{array}$ \\
\hline 28 U.S.C. $\$ 294$ & $\begin{array}{l}\text { The Chief Justice maintains a roster of retired district and } \\
\text { circuit judges willing to undertake judicial duties. }\end{array}$ \\
\hline 28 U.S.C. $§ 295$ & $\begin{array}{l}\text { The Chief Justice may revoke designations of district and cir- } \\
\text { cuit judges to other courts. }\end{array}$ \\
\hline 28 U.S.C. $\$ 297$ & $\begin{array}{l}\text { The Chief Justice may assign judges to serve on the courts of } \\
\text { the freely associated compact states when officials of those } \\
\text { courts certify necessity and the assigned judges agree. }\end{array}$ \\
\hline 28 U.S.C. $\$ 331$ & $\begin{array}{l}\text { The Chief Justice calls annual and special meetings of the } \\
\text { Judicial Conference and designates the time and place for } \\
\text { such meetings. }\end{array}$ \\
\hline 28 U.S.C. $§ 331$ & $\begin{array}{l}\text { The Chief Justice presides over meetings of the Judicial Con- } \\
\text { ference. }\end{array}$ \\
\hline
\end{tabular}

* The Special Division's authority to appoint independent counsels lapsed in 1999. The Special Division continues to oversee previously initiated investigations and to dispose of petitions for attorneys' fees in concluded matters. 


\begin{tabular}{|c|c|}
\hline 28 U.S.C. $\$ 331$ & $\begin{array}{l}\text { Every judge summoned to the Judicial Conference shall at- } \\
\text { tend unless excused by the Chief Justice. If a judge desig- } \\
\text { nated as a member of the Conference is unable to attend, the } \\
\text { Chief Justice may summon a replacement judge. }\end{array}$ \\
\hline 28 U.S.C. $\$ 331$ & $\begin{array}{l}\text { If the Judicial Conference elects to establish a standing com- } \\
\text { mittee for judicial discipline matters, the Chief Justice ap- } \\
\text { points the members of that committee. }\end{array}$ \\
\hline 28 U.S.C. $\$ 331$ & $\begin{array}{l}\text { The Chief Justice may order subpoenas to be issued in con- } \\
\text { nection with Judicial Conference judicial discipline proceed- } \\
\text { ings. }\end{array}$ \\
\hline 28 U.S.C. $\$ 331$ & $\begin{array}{l}\text { The Chief Justice may summon the Attorney General to re- } \\
\text { port to the Judicial Conference on matters related to the } \\
\text { courts and, particularly, related to the United States as a party } \\
\text { before the courts. }\end{array}$ \\
\hline 28 U.S.C. $§ 331$ & $\begin{array}{l}\text { The Chief Justice submits to Congress an annual report of the } \\
\text { proceedings of the Judicial Conference and its recommenda- } \\
\text { tions for legislation. }\end{array}$ \\
\hline 28 U.S.C. $\$ 360$ & $\begin{array}{l}\text { Judicial Conference investigations for judicial discipline pur- } \\
\text { poses cannot be disclosed unless authorized by the judge be- } \\
\text { ing investigated and by the Chief Justice, the chief judge of } \\
\text { the circuit, or the chairman of the standing committee. }\end{array}$ \\
\hline 28 U.S.C. $\$ 371$ & $\begin{array}{l}\text { The Chief Justice must certify annually that a Justice sitting as } \\
\text { a Senior Justice continues to qualify for that status. }\end{array}$ \\
\hline 28 U.S.C. $\$ 371$ & $\begin{array}{l}\text { The Chief Justice certifies the temporary or permanent dis- } \\
\text { ability of a Senior Justice. }\end{array}$ \\
\hline 28 U.S.C. $\$ 372$ & $\begin{array}{l}\text { The Chief Justice signs certificates of permanent disability } \\
\text { authorizing the voluntary early retirement of Justices and } \\
\text { chief judges. }\end{array}$ \\
\hline 28 U.S.C. $\$ 372$ & $\begin{array}{l}\text { The Chief Justice may present a certificate of permanent dis- } \\
\text { ability to the President to recommend involuntary retirement } \\
\text { of the Chief Judge of the Court of International Trade. }\end{array}$ \\
\hline 28 U.S.C. $\$ 601$ & $\begin{array}{l}\text { The Chief Justice appoints and can remove, on consultation } \\
\text { with the Judicial Conference, the Director and Deputy Direc- } \\
\text { tor of the Administrative Office of the United States Courts. }\end{array}$ \\
\hline 28 U.S.C. $\$ 611$ & $\begin{array}{l}\text { The Director of the Administrative Office of the United States } \\
\text { Courts may elect special retirement coverage by filing a writ- } \\
\text { ten form with the Chief Justice. }\end{array}$ \\
\hline 28 U.S.C. $\$ 621$ & $\begin{array}{l}\text { The Chief Justice serves as the permanent chair of the Board } \\
\text { of the Federal Judicial Center. }\end{array}$ \\
\hline 28 U.S.C. $\$ 629$ & $\begin{array}{l}\text { The Chief Justice appoints three of the seven members, in- } \\
\text { cluding the chair, of the Federal Judicial Center Foundation } \\
\text { Board, which receives gifts and property for use by the Federal } \\
\text { Judicial Center. }\end{array}$ \\
\hline 28 U.S.C. $\$ 671$ & $\begin{array}{l}\text { The Chief Justice authorizes the Supreme Court Clerk to re- } \\
\text { move deputy clerks. }\end{array}$ \\
\hline 28 U.S.C. $\$ 671$ & $\begin{array}{l}\text { With the approval of the Chief Justice, the Supreme Court } \\
\text { Clerk appoints and sets compensation for deputy clerks. }\end{array}$ \\
\hline & $\begin{array}{l}\text { With the approval of the Chief Justice, the Supreme Court } \\
\text { Marshal appoints and fixes compensation for assistants. }\end{array}$ \\
\hline
\end{tabular}




\begin{tabular}{|c|c|}
\hline 28 U.S.C. $\$ 673$ & $\begin{array}{l}\text { With the approval of the Chief Justice, the Supreme Court } \\
\text { Reporter appoints and fixes compensation for assistants. }\end{array}$ \\
\hline 28 U.S.C. $\$ 673$ & $\begin{array}{l}\text { The Supreme Court Reporter, under the direction of the } \\
\text { Chief Justice or the Supreme Court, prepares the Supreme } \\
\text { Court's decisions for publication. }\end{array}$ \\
\hline 28 U.S.C. $\$ 674$ & $\begin{array}{l}\text { With the approval of the Chief Justice, the Supreme Court } \\
\text { librarian appoints and fixes compensation for assistants and } \\
\text { sets the rules governing the use of the library. }\end{array}$ \\
\hline 28 U.S.C. $\$ 675$ & $\begin{array}{l}\text { The Chief Justice and the Associate Justices of the Supreme } \\
\text { Court may appoint law clerks and secretaries whose salaries } \\
\text { shall be fixed by the Court. }\end{array}$ \\
\hline 28 U.S.C. $\$ 676$ & $\begin{array}{l}\text { Either the Chief Justice or the Supreme Court selects the Su- } \\
\text { preme Court's printer. }\end{array}$ \\
\hline 28 U.S.C. $\$ 676$ & $\begin{array}{l}\text { Either the Chief Justice or the Supreme Court determines the } \\
\text { manner in which Court decisions are printed. }\end{array}$ \\
\hline 28 U.S.C. $\$ 677$ & $\begin{array}{l}\text { The Chief Justice appoints the Administrative Assistant to the } \\
\text { Chief Justice and determines the level of compensation and } \\
\text { duties for that position. }\end{array}$ \\
\hline 28 U.S.C. $\$ 677$ & $\begin{array}{l}\text { The Chief Justice approves compensation for additional em- } \\
\text { ployees needed by the Administrative Assistant to the Chief } \\
\text { Justice. }\end{array}$ \\
\hline 28 U.S.C. $\$ 677$ & $\begin{array}{l}\text { The Chief Justice approves acceptance of volunteer services by } \\
\text { the Administrative Assistant to the Chief Justice. }\end{array}$ \\
\hline 28 U.S.C. $\$ 1407$ & $\begin{array}{l}\text { The Chief Justice may transfer a judge from the judge's dis- } \\
\text { trict or circuit to a court to which multidistrict litigation has } \\
\text { been transferred. }\end{array}$ \\
\hline 28 U.S.C. $\$ 1407$ & $\begin{array}{l}\text { The Chief Justice appoints the seven members of the Multidis- } \\
\text { trict Litigation Panel. }\end{array}$ \\
\hline 28 U.S.C. $\$ 2109$ & $\begin{array}{l}\text { If the Supreme Court does not have a quorum to hear a case, } \\
\text { the Chief Justice may order the case remitted to the court of } \\
\text { appeals for hearing by either, at the Chief Justice's discretion, } \\
\text { three judges or the court en banc. }\end{array}$ \\
\hline 40 U.S.C. $\$ 6102$ & $\begin{array}{l}\text { The Chief Justice approves the Supreme Court Marshal's regu- } \\
\text { lations for protection and maintenance of the Supreme Court } \\
\text { building. }\end{array}$ \\
\hline 40 U.S.C. $\$ 6112$ & $\begin{array}{l}\text { The Chief Justice approves the hiring of employees for the } \\
\text { maintenance of the Supreme Court's building and grounds. }\end{array}$ \\
\hline 40 U.S.C. $\$ 6121$ & $\begin{array}{l}\text { The Chief Justice approves the Supreme Court Marshal's regu- } \\
\text { lations for the Supreme Court police. }\end{array}$ \\
\hline 40 U.S.C. $\$ 6122$ & $\begin{array}{l}\text { Under the general supervision and direction of the Chief Jus- } \\
\text { tice, the Supreme Court Marshal designates Supreme Court } \\
\text { employees as members of the Supreme Court police. }\end{array}$ \\
\hline 40 U.S.C. $\$ 6502$ & $\begin{array}{l}\text { The Chief Justice or the Chief Justice's designee was charged } \\
\text { with approving the final architectural plans for the Thurgood } \\
\text { Marshall Federal Judiciary Building. }\end{array}$ \\
\hline 40 U.S.C. $\$ 6503$ & $\begin{array}{l}\text { The Chief Justice appoints two of the thirteen members of the } \\
\text { Commission for the Judiciary Office Building. }\end{array}$ \\
\hline 40 U.S.C. $\$ 6506$ & $\begin{array}{l}\text { The Chief Justice was to determine what space was needed by } \\
\text { the judiciary in the Thurgood Marshall Federal Judiciary } \\
\text { Building and to inform the Architect of the Capitol. }\end{array}$ \\
\hline
\end{tabular}




\begin{tabular}{|c|c|}
\hline 40 U.S.C. $\$ 6506$ & $\begin{array}{l}\text { The Chief Justice notifies the Architect when the judiciary } \\
\text { requires additional space in the Thurgood Marshall Federal } \\
\text { Judiciary Building. }\end{array}$ \\
\hline 42 U.S.C. $\$ 659$ & $\begin{array}{l}\text { The Chief Justice may promulgate regulations for the judicial } \\
\text { branch to implement consent to income withholding, gar- } \\
\text { nishment, and similar proceedings for enforcement of child } \\
\text { support and alimony obligations. }\end{array}$ \\
\hline 44 U.S.C. $\$ 2501$ & $\begin{array}{l}\text { The Chief Justice appoints a member of the judiciary as one of } \\
\text { the fifteen members of the National Historical Publications } \\
\text { and Records Commission. }\end{array}$ \\
\hline 44 U.S.C. $\$ 3318$ & $\begin{array}{l}\text { The Chief Justice appoints a member of the judiciary as one of } \\
\text { the seventeen members of the National Study Commission on } \\
\text { Records and Documents of Federal Officials. }\end{array}$ \\
\hline 48 U.S.C. $\$ 1424 b$ & $\begin{array}{l}\text { The Chief Justice may assign a circuit or district judge from } \\
\text { another circuit to serve temporarily as a judge in the District } \\
\text { of Guam whenever such assignment is necessary and the as- } \\
\text { signed judge and the chief judge of the assigned judge's cir- } \\
\text { cuit consent. }\end{array}$ \\
\hline 48 U.S.C. $\$ 1614$ & $\begin{array}{l}\text { The Chief Justice, after obtaining the consent of the assigned } \\
\text { judge and the assigned judge's circuit, may assign a circuit or } \\
\text { district judge to serve temporarily on the District Court of the } \\
\text { Virgin Islands. }\end{array}$ \\
\hline 48 U.S.C. $\$ 1821$ & $\begin{array}{l}\text { The Chief Justice, after obtaining the consent of the assigned } \\
\text { judge and the assigned judge's circuit, may assign a circuit or } \\
\text { district judge to serve temporarily on the District Court for the } \\
\text { Northern Mariana Islands. }\end{array}$ \\
\hline 50 U.S.C. $\$ 1802$ & $\begin{array}{l}\text { The Chief Justice, with the concurrence of the Attorney Gen- } \\
\text { eral and in consultation with the Director of National Intelli- } \\
\text { gence, establishes security measures for maintaining the At- } \\
\text { torney General's certification for electronic surveillance to } \\
\text { acquire foreign intelligence. }\end{array}$ \\
\hline 50 U.S.C. $\$ 1803$ & $\begin{array}{l}\text { The Chief Justice appoints the eleven district judges who } \\
\text { make up the Foreign Intelligence Surveillance Court. }\end{array}$ \\
\hline 50 U.S.C. $\$ 1803$ & $\begin{array}{l}\text { The Chief Justice appoints three district or circuit court } \\
\text { judges to serve as an appellate board to review any denial by } \\
\text { the Foreign Intelligence Surveillance Court of an application } \\
\text { by the government for surveillance authorization. }\end{array}$ \\
\hline 50 U.S.C. $\$ 1803$ & $\begin{array}{l}\text { Proceedings under the Foreign Intelligence Surveillance Act } \\
\text { are conducted under security measures established by the } \\
\text { Chief Justice in consultation with the Attorney General and } \\
\text { the Director of National Intelligence. }\end{array}$ \\
\hline 50 U.S.C. $\$ 1822$ & $\begin{array}{l}\text { The Chief Justice, with the concurrence of the Attorney Gen- } \\
\text { eral and in consultation with the Director of National Intelli- } \\
\text { gence, establishes the security measures under which the At- } \\
\text { torney General's certifications of the need for physical } \\
\text { searches, conducted for foreign intelligence surveillance pur- } \\
\text { poses and undertaken without court orders, are to be kept. }\end{array}$ \\
\hline
\end{tabular}




\begin{tabular}{ll}
\hline 50 U.S.C. $\$ 1822$ & $\begin{array}{l}\text { Records of proceedings under the Foreign Intelligence Sur- } \\
\text { veillance Act, including applications made and orders } \\
\text { granted, shall be maintained under security measures estab- } \\
\text { lished by the Chief Justice in consultation with the Attorney } \\
\text { General and the Director of National Intelligence. }\end{array}$ \\
\hline 50 U.S.C. $\$ 1842$ & $\begin{array}{l}\text { The Chief Justice appoints a U.S. magistrate judge to hear } \\
\text { applications for and grant orders approving the installation } \\
\text { and use of pen register or trap and trace devices under the } \\
\text { Foreign Intelligence Surveillance Act. }\end{array}$ \\
\hline 50 U.S.C. $\$ 1861$ & $\begin{array}{l}\text { The Chief Justice appoints a U.S. magistrate judge to hear } \\
\text { applications for the production of tangible things under the } \\
\text { Foreign Intelligence Surveillance Act. }\end{array}$ \\
\hline
\end{tabular}


APPENDIX C

Tenure and Methods of Selection of State Chief Justices (as of 2005)

\begin{tabular}{|c|c|c|c|c|}
\hline \multirow[b]{2}{*}{ States } & \multicolumn{2}{|c|}{ Chief Justice } & \multicolumn{2}{|c|}{ Other Justices } \\
\hline & Tenure & Selection Method & Tenure & Selection Method \\
\hline \multirow[t]{2}{*}{ Alabama } & 6 years & Popular election & 6 years & Popular election \\
\hline & $\begin{array}{l}\text { ALA. CODE } \S \\
12-2-1\end{array}$ & ALA. CODE $§ 12-2-1$ & $\begin{array}{l}\text { ALA. CONST. art. } \\
\text { VI, } \$ 154(a) ; \\
\text { ALA. CODE } § 12- \\
2-1\end{array}$ & $\begin{array}{l}\text { ALA. CONST. art. VI, } \S 152 \text {; } \\
\text { ALA. CODE } \S 12-2-1\end{array}$ \\
\hline \multirow[t]{3}{*}{ Alaska } & 3 years & Court selection & 10 years & $\begin{array}{l}\text { JNC nominates; governor } \\
\text { appoints; retention election }\end{array}$ \\
\hline & & & $\begin{array}{l}\text { Initial term }=\text { at } \\
\text { least } 3 \text { years }\end{array}$ & \\
\hline & $\begin{array}{l}\text { ALASKA CONST. } \\
\text { art. IV, } \S 2(\mathrm{~b})\end{array}$ & $\begin{array}{l}\text { ALASKA CONST. art. IV, } \S \\
2 \text { (b) }\end{array}$ & $\begin{array}{l}\text { ALASKA CONST. } \\
\text { art. IV, } \S 6\end{array}$ & $\begin{array}{l}\text { ALASKA CONST. art. IV, } \$ \S 5 \text { - } \\
6\end{array}$ \\
\hline \multirow[t]{3}{*}{ Arizona } & 5 years & Court selection & 6 years & $\begin{array}{l}\text { JNC nominates; governor } \\
\text { appoints; retention election }\end{array}$ \\
\hline & & & $\begin{array}{l}\text { Initial term = at } \\
\text { least } 2 \text { years }\end{array}$ & \\
\hline & $\begin{array}{l}\text { ARIZ. CONST. } \\
\text { art. VI, } \S 3\end{array}$ & ARIZ. CONST. art. VI, $\S 3$ & $\begin{array}{l}\text { ARIZ. CONST. art. } \\
\text { VI, } \$ \S 4,37(\mathrm{C})\end{array}$ & $\begin{array}{l}\text { ARIZ. CONST. art. VI, } \$ \S 37- \\
38\end{array}$ \\
\hline \multirow[t]{2}{*}{ Arkansas } & 8 years & Popular election & 8 years & Popular election \\
\hline & $\begin{array}{l}\text { ARK. CONST. } \\
\text { amend. } 80, \S \S \\
2(\mathrm{~B}), 16(\mathrm{~A})\end{array}$ & $\begin{array}{l}\text { ARK. CONST. amend. } 9, \S 1 \text {; } \\
\text { ARK. CONST. amend. } 80, \S \S \\
2(\mathrm{~A}),(\mathrm{B}), 18\end{array}$ & $\begin{array}{l}\text { ARK. CONST. } \\
\text { amend. } 80, \S \\
16(\mathrm{~A})\end{array}$ & $\begin{array}{l}\text { ARK. CONST. amend. } 80, \S \S \\
2(\mathrm{~A}), 18\end{array}$ \\
\hline \multirow[t]{2}{*}{ California } & 12 years & $\begin{array}{l}\text { Governor nominates after } \\
\text { review by Commission on } \\
\text { Judicial Nominees Evalua- } \\
\text { tion; Commission on } \\
\text { Judicial Appointments } \\
\text { approves; retention elec- } \\
\text { tion }\end{array}$ & $\begin{array}{l}12 \text { years } \\
\text { Initial term = } \\
\text { until next } \\
\text { gubernatorial } \\
\text { election }\end{array}$ & $\begin{array}{l}\text { Governor nominates after } \\
\text { review by Commission on } \\
\text { Judicial Nominees Evalua- } \\
\text { tion; Commission on Judi- } \\
\text { cial Appointments approves; } \\
\text { retention election }\end{array}$ \\
\hline & $\begin{array}{l}{ }^{a, b} \text { CAL. CONST. } \\
\text { art. VI, } \S \\
\text { 16(a); CAL. } \\
\text { ELEC. CODE } \$ \S \\
\text { 9083, } 13109\end{array}$ & $\begin{array}{l}{ }^{a, b} \text { CAL. CONST. art. VI, } \S \\
\text { 16(a), (d); CAL. ELEC. } \\
\text { CODE } \$ \$ 9083,13109\end{array}$ & $\begin{array}{l}\text { CAL. CONST. art. } \\
\text { VI, } \$ 16(\mathrm{a}),(\mathrm{d}) ; \\
\text { CAL. ElEC. CODE } \\
\S 9083\end{array}$ & $\begin{array}{l}\text { CAL. CONST. art. VI, } \S 16(\mathrm{a}) \text {, } \\
\text { (d); CAL. ElEC. CODE } \$ \S \\
9083,13109\end{array}$ \\
\hline \multirow[t]{2}{*}{ Colorado } & $\begin{array}{l}\text { Serves "at the } \\
\text { pleasure of a } \\
\text { majority of the } \\
\text { court" }\end{array}$ & Court selection & $\begin{array}{l}10 \text { years } \\
\text { Initial term = at } \\
\text { least } 2 \text { years }\end{array}$ & $\begin{array}{l}\text { JNC nominates; governor } \\
\text { appoints; retention election }\end{array}$ \\
\hline & $\begin{array}{l}\text { COLO. CONST. } \\
\text { art. VI, } \$ 5(2)\end{array}$ & $\begin{array}{l}\text { COLO. CONST. art. VI, } \S \\
5(2)\end{array}$ & $\begin{array}{l}\text { COLO. CONST. } \\
\text { art. VI, } \S \S 7,20\end{array}$ & $\begin{array}{l}\text { Colo. CONST. art. VI, } \$ \S 20 \text {, } \\
25\end{array}$ \\
\hline \multirow[t]{2}{*}{ Connecticut } & 8 years & $\begin{array}{l}\text { JNC proposes; governor } \\
\text { nominates; legislature } \\
\text { appoints }\end{array}$ & 8 years & $\begin{array}{l}\text { JNC proposes; governor } \\
\text { nominates; legislature ap- } \\
\text { points }\end{array}$ \\
\hline & $\begin{array}{l}\text { CONN. GEN. } \\
\text { STAT. ANN. § } \\
51-44 \mathrm{a}(\mathrm{h})\end{array}$ & $\begin{array}{l}\text { CONN. Const. art. V, } § 2 \text {; } \\
\text { CONN. GEN. StAT. ANN. } \$ \\
51-44 a(h)\end{array}$ & $\begin{array}{l}\text { CONN. CONST. } \\
\text { art. V, } \S 2\end{array}$ & $\begin{array}{l}\text { CONN. CONST. art. V, } \$ 2 \\
\text { CONN. GEN. STAT. ANN. } § 51- \\
44 \mathrm{a}(\mathrm{h})\end{array}$ \\
\hline
\end{tabular}




\begin{tabular}{|c|c|c|c|c|}
\hline \multirow[b]{2}{*}{ States } & \multicolumn{2}{|c|}{ Chief Justice } & \multicolumn{2}{|c|}{ Other Justices } \\
\hline & Tenure & Selection Method & Tenure & Selection Method \\
\hline \multirow[t]{2}{*}{ Delaware } & 12 years & $\begin{array}{l}\text { JNC nominates; governor } \\
\text { appoints; senate consents }\end{array}$ & 12 years & $\begin{array}{l}\text { JNC nominates; governor } \\
\text { appoints; senate consents }\end{array}$ \\
\hline & $\begin{array}{l}\text { DEL. CONST. } \\
\text { art. IV, } \S 3\end{array}$ & $\begin{array}{l}\text { DEL. CONST. art. IV } \S \S 2,3 \text {; } \\
\text { Exec. Order No. } 4\end{array}$ & $\begin{array}{l}\text { DEL. CONST. art. } \\
\text { IV, } \S 3\end{array}$ & $\begin{array}{l}\text { DEL. CONST. art. IV, } \$ 3 \text {; } \\
\text { Exec. Order No. } 4\end{array}$ \\
\hline \multirow[t]{2}{*}{$\begin{array}{l}\text { District of } \\
\text { Columbia }\end{array}$} & 4 years & Designated by JNC & $\begin{array}{l}15 \text { years; manda- } \\
\text { tory retirement } \\
\text { at age } 74\end{array}$ & $\begin{array}{l}\text { JNC nominates; President } \\
\text { appoints; senate consents }\end{array}$ \\
\hline & $\begin{array}{l}\text { D.C. CODE } § \\
11-1503(\mathrm{a})\end{array}$ & D.C. CODE $§ 1-204.31$ (b) & $\begin{array}{l}\text { D.C. CODE } \$ 11- \\
1502\end{array}$ & $\begin{array}{l}\text { D.C. CODE. \$§ 1-204.33, 11- } \\
1501 \text { (a) }\end{array}$ \\
\hline \multirow[t]{3}{*}{ Florida } & 2 years & Court selection & 6 years & $\begin{array}{l}\text { JNC nominates; governor } \\
\text { appoints; retention election }\end{array}$ \\
\hline & & & $\begin{array}{l}\text { Initial term }=\text { at } \\
\text { least } 1 \text { year }\end{array}$ & \\
\hline & $\begin{array}{l}\text { FLA. R. JUD. } \\
\text { ADMIN. } \\
2.030(\mathrm{a})(2)(\mathrm{A})\end{array}$ & $\begin{array}{l}\text { FLA. CONST. art. V, } \S 2(\mathrm{~b}) ; \\
\text { FLA. R. JUD. ADMIN. } \\
2.030(\mathrm{a})(2)(\mathrm{A})\end{array}$ & $\begin{array}{l}\text { FLA. CONST. art. } \\
\text { V, } \$ \$ 10(\mathrm{a}) \\
11(\mathrm{a})\end{array}$ & $\begin{array}{l}\text { FLA. CONST. art. V, } \$ \S 10 \text { (a), } \\
11 \text { (a) }\end{array}$ \\
\hline \multirow[t]{2}{*}{ Georgia } & $\begin{array}{l}2 \text { years } \\
\text { (no more than } \\
4 \text { years) }\end{array}$ & Court selection & 6 years & Popular election \\
\hline & $\begin{array}{l}\text { '1999 Ga. } \\
\text { Supreme } \\
\text { Court } \\
\text { Administrative } \\
\text { Minutes }\end{array}$ & $\begin{array}{l}\text { GA. CoNST. art. VI, } \$ 6 \text {, } \\
\text { para. } 1\end{array}$ & $\begin{array}{l}\text { GA. CONST. art. } \\
6, \S 7 \text {, para. } 1\end{array}$ & $\begin{array}{l}\text { GA. CONST. art. } 6, \S 7 \text {, para. } \\
1\end{array}$ \\
\hline \multirow[t]{2}{*}{ Hawaii } & $\begin{array}{l}10 \text { years; man- } \\
\text { datory retire- } \\
\text { ment at age } 70\end{array}$ & $\begin{array}{l}\text { JNC nominates; governor } \\
\text { appoints; senate consents }\end{array}$ & $\begin{array}{l}10 \text { years; manda- } \\
\text { tory retirement } \\
\text { at age } 70\end{array}$ & $\begin{array}{l}\text { JNC nominates; governor } \\
\text { appoints; senate consents }\end{array}$ \\
\hline & $\begin{array}{l}\text { HAW. CONST. } \\
\text { art. VI, } \$ 3\end{array}$ & HAW. CONST. art. VI, $\S 3$ & $\begin{array}{l}\text { HAW. CONST. } \\
\text { art. VI, } \S 3 \\
\end{array}$ & HAW. CONST. art. VI, § 3 \\
\hline \multirow[t]{2}{*}{ Idaho } & 4 years & Court selection & 6 years & Popular election \\
\hline & $\begin{array}{l}\text { IDAHO CONST. } \\
\text { art. V, } \S 6 \\
\end{array}$ & IDAHO CONST. art. V, $\S 6$ & $\begin{array}{l}\text { IDAHO CONST. } \\
\text { art. V, } \S 6 \\
\end{array}$ & IDAHO CONST. art. V, $\S 6$ \\
\hline \multirow[t]{2}{*}{ Illinois } & 3 years & Court selection & 10 years & $\begin{array}{l}\text { Popular election; retention } \\
\text { election }\end{array}$ \\
\hline & $\begin{array}{l}\text { ILL. CONST. art. } \\
\text { VI, } \S 3 \\
\end{array}$ & ILL. CONST. art. VI, § 3 & $\begin{array}{l}\text { ILL. CONST. art. } \\
\text { VI, } § 10 \\
\end{array}$ & ILL. CONST. art. VI, § 12 \\
\hline \multirow[t]{3}{*}{ Indiana } & 5 years & JNC appoints & 10 years & $\begin{array}{l}\text { JNC nominates; governor } \\
\text { appoints; retention election }\end{array}$ \\
\hline & & & $\begin{array}{l}\text { Initial term = at } \\
\text { least } 2 \text { years }\end{array}$ & \\
\hline & $\begin{array}{l}\text { IND. CONST. } \\
\text { art. VII, } \S 3 \\
\end{array}$ & IND. CONST. art. VII, $§ 3$ & $\begin{array}{l}\text { IND. CONST. art. } \\
\text { VII, } \S 11\end{array}$ & $\begin{array}{l}\text { IND. CONST. art. VII, } \S \S 10- \\
11\end{array}$ \\
\hline \multirow[t]{3}{*}{ Iowa } & 8 years & Court selection & 8 years & $\begin{array}{l}\text { JNC nominates; governor } \\
\text { appoints; retention election }\end{array}$ \\
\hline & & & $\begin{array}{l}\text { Initial term = at } \\
\text { least } 1 \text { year }\end{array}$ & \\
\hline & $\begin{array}{l}\text { IOWA CODE } \\
\text { ANN. } \$ \\
602.4103\end{array}$ & $\begin{array}{l}\text { IOWA CODE. ANN. } \$ \\
602.4103\end{array}$ & $\begin{array}{l}\text { IOWA CONST. art. } \\
\mathrm{V}, \S 17\end{array}$ & $\begin{array}{l}\text { IOWA CONST. art. V, } \$ \S 15 \text {, } \\
17\end{array}$ \\
\hline
\end{tabular}




\begin{tabular}{|c|c|c|c|c|}
\hline \multirow[b]{2}{*}{ States } & \multicolumn{2}{|c|}{ Chief Justice } & \multicolumn{2}{|c|}{ Other Justices } \\
\hline & Tenure & Selection Method & Tenure & Selection Method \\
\hline \multirow[t]{3}{*}{ Kansas } & $\begin{array}{l}\text { Duration of } \\
\text { service }\end{array}$ & Seniority & 6 years & $\begin{array}{l}\text { JNC nominates; governor } \\
\text { appoints; retention election }\end{array}$ \\
\hline & & & $\begin{array}{l}\text { Initial term = at } \\
\text { least } 1 \text { year }\end{array}$ & \\
\hline & $\begin{array}{l}\text { KAN. CONST. } \\
\text { art. III, } \S 2\end{array}$ & KAN. CONST. art. III, $\S 2$ & $\begin{array}{l}\text { KAN. CONST. art. } \\
\text { III, } \S \S 2,5\end{array}$ & KAN. CONST. art. III, $\$ 5$ \\
\hline \multirow[t]{2}{*}{ Kentucky } & 4 years & Court selection & 8 years & Popular election \\
\hline & $\begin{array}{l}\text { KY. CONST. } \S \\
110(5)(\mathrm{a})\end{array}$ & KY. CONST. $\$ 110(5)(a)$ & Ky. CONST. § 119 & Ky. CONST. $§ 117$ \\
\hline \multirow[t]{2}{*}{ Louisiana } & $\begin{array}{l}\text { Duration of } \\
\text { service }\end{array}$ & Seniority & 10 years & Popular election \\
\hline & $\begin{array}{l}\text { LA. CONST. art. } \\
\mathrm{V}, \S 6\end{array}$ & LA. CONST. art. V, $\S 6$ & $\begin{array}{l}\text { LA. CONST. art. } \\
\mathrm{V}, \S 3\end{array}$ & LA. CONST. art. V, § 22(A) \\
\hline \multirow[t]{2}{*}{ Maine } & 7 years & $\begin{array}{l}\text { Governor appoints; senate } \\
\text { confirms }\end{array}$ & 7 years & $\begin{array}{l}\text { Governor appoints; senate } \\
\text { confirms }\end{array}$ \\
\hline & $\begin{array}{l}{ }^{a} \text { ME. CONST. } \\
\text { art. VI, } \$ 4\end{array}$ & $\begin{array}{l}{ }^{a} \text { ME. CONST. art. V, pt. } 1, \S \\
8\end{array}$ & $\begin{array}{l}\text { ME. CONST. art. } \\
\text { VI, } \S 4\end{array}$ & ME. Const. art. V, pt. $1, \S 8$ \\
\hline \multirow[t]{3}{*}{ Maryland } & $\begin{array}{l}10 \text { years; man- } \\
\text { datory retire- } \\
\text { ment at age } 70\end{array}$ & Governor designates & $\begin{array}{l}10 \text { years; manda- } \\
\text { tory retirement } \\
\text { at age } 70\end{array}$ & $\begin{array}{l}\text { JNC nominates; governor } \\
\text { appoints; senate confirms; } \\
\text { retention election }\end{array}$ \\
\hline & & & $\begin{array}{l}\text { Initial term }=\text { at } \\
\text { least } 1 \text { year }\end{array}$ & \\
\hline & $\begin{array}{l}{ }^{a} \text { MD. CONST. } \\
\text { art. IV, } \$ \S 5 \mathrm{~A} \text {, } \\
14\end{array}$ & MD. CONST. art. IV, § 14 & $\begin{array}{l}\text { MD. Const. art. } \\
\text { IV, } \S 5 \mathrm{~A}\end{array}$ & $\begin{array}{l}\text { MD. ConsT. art. IV, } \S 5 \mathrm{~A} ; \\
\text { Md. Exec. Order } \\
01.01 .2003 .09\end{array}$ \\
\hline \multirow[t]{2}{*}{ Massachusetts } & $\begin{array}{l}\text { "[G] ood be- } \\
\text { havior;" man- } \\
\text { datory retire- } \\
\text { ment at age } 70\end{array}$ & $\begin{array}{l}\text { Governor appoints; gover- } \\
\text { nor's council consents }\end{array}$ & $\begin{array}{l}\text { "[G]ood behav- } \\
\text { ior"; mandatory } \\
\text { retirement at } \\
\text { age } 70\end{array}$ & $\begin{array}{l}\text { Governor appoints; gover- } \\
\text { nor's council consents }\end{array}$ \\
\hline & $\begin{array}{l}{ }^{a} \text { MASS. CONST. } \\
\text { pt. } 1 \text {, art. } 29 ; \\
\text { MASs. CONST. } \\
\text { pt. } 2 \text {, ch. } 3 \text {, art. } \\
1\end{array}$ & $\begin{array}{l}{ }^{a} \text { MASS. CONST. pt. } 2 \text {, ch. } 2 \text {, } \\
\S 1 \text {, art. } 9\end{array}$ & $\begin{array}{l}\text { MASs. CONST. pt. } \\
\text { 1, art. 29; MASS. } \\
\text { CONST. pt. 2, ch. } \\
\text { 3, art. } 1\end{array}$ & $\begin{array}{l}\text { MASs. CONST. pt. } 2 \text {, ch. } 2, \S \\
\text { 1, art. } 9 \text {; Ma. Exec. Order } \\
\text { No. } 470\end{array}$ \\
\hline \multirow[t]{2}{*}{ Michigan } & 2 years & Court selection & 8 years & Popular election \\
\hline & $\begin{array}{l}{ }^{c} \mathrm{MiCH} . \mathrm{CT} . \mathrm{R} . \\
7.323\end{array}$ & $\begin{array}{l}\text { MICH. CONST. art. VI, } \$ 3 \text {; } \\
\text { MICH. CT. R. } 7.323\end{array}$ & $\begin{array}{l}\text { MICH. CONST. } \\
\text { art. VI, } \S 2\end{array}$ & MICH. CONST. art. VI, $§ 2$ \\
\hline \multirow[t]{2}{*}{ Minnesota } & 6 years & Popular election & 6 years & Popular election \\
\hline & $\begin{array}{l}{ }^{a} \text { MINN. CONST. } \\
\text { art. VI, } \S 7\end{array}$ & $\begin{array}{l}{ }^{a, b} \text { MinN. CONST. art. VI, } \S 7 \text {; } \\
\text { MINN. STAT. ANN. } \S \\
\text { 204B.06(6) }\end{array}$ & $\begin{array}{l}\text { MINN. CONST. } \\
\text { art. VI, } \S 7\end{array}$ & MINN. CONST. art. VI, $\$ 7$ \\
\hline \multirow[t]{2}{*}{ Mississippi } & $\begin{array}{l}\text { Duration of } \\
\text { service }\end{array}$ & Seniority & 8 years & Popular election \\
\hline & $\begin{array}{l}\text { MIss. CODE } \\
\text { ANN. } § 9-3-11\end{array}$ & Miss. CODE ANN. § 9-3-11 & $\begin{array}{l}\text { MISs. CONST. art. } \\
\text { VI, } \$ 149\end{array}$ & MISs. CONST. art. VI, § 145 \\
\hline
\end{tabular}




\begin{tabular}{|c|c|c|c|c|}
\hline \multirow[b]{2}{*}{ States } & \multicolumn{2}{|c|}{ Chief Justice } & \multicolumn{2}{|c|}{ Other Justices } \\
\hline & Tenure & Selection Method & Tenure & Selection Method \\
\hline \multirow[t]{3}{*}{ Missouri } & 2 years & Court selection & 12 years & $\begin{array}{l}\text { JNC nominates; governor } \\
\text { appoints; retention election }\end{array}$ \\
\hline & & & $\begin{array}{l}\text { Initial term= at } \\
\text { least } 1 \text { year }\end{array}$ & \\
\hline & $\begin{array}{l}\text { 'Mo. ConsT. } \\
\text { art. V, § 8; Mo. } \\
\text { Sup. CT. R. } \\
82.01\end{array}$ & $\begin{array}{l}\text { Mo. CONST. art. V, } \S 8 \text {; } \\
\text { Mo. SuP. CT. R. } 82.01\end{array}$ & $\begin{array}{l}\text { Mo. Const. art. } \\
\text { V, § 19; Mo. } \\
\text { Const. art. V, } \$ \\
25(\mathrm{c})\end{array}$ & $\begin{array}{l}\text { Mo. ConST. art. V, } \S 25(\mathrm{a}) \text {, } \\
\text { (c) }\end{array}$ \\
\hline \multirow[t]{2}{*}{ Montana } & 8 years & Popular election & 8 years & Popular election \\
\hline & $\begin{array}{l}\text { MonT. CODE } \\
\text { ANN. } \$ 3-2-101\end{array}$ & $\begin{array}{l}\text { MONT. CONST. art. VII, § } 8 \text {; } \\
\text { MONT. CODE ANN. § 3-2- } \\
101\end{array}$ & $\begin{array}{l}\text { MONT. CONST. } \\
\text { art. VII, § 7; } \\
\text { MONT. CODE } \\
\text { ANN. } § 3-2-101 \\
\end{array}$ & $\begin{array}{l}\text { MONT. CONST. art. VII, §8; } \\
\text { MonT. CODE ANN. § 3-2-101 }\end{array}$ \\
\hline \multirow[t]{3}{*}{ Nebraska } & 6 years & $\begin{array}{l}\text { JNC nominates; governor } \\
\text { appoints; retention elec- }\end{array}$ & 6 years & $\begin{array}{l}\text { JNC nominates; governor } \\
\text { appoints; retention election }\end{array}$ \\
\hline & $\begin{array}{l}\text { Initial term }= \\
\text { at least } 3 \text { years }\end{array}$ & tion & $\begin{array}{l}\text { Initial term }=\text { at } \\
\text { least } 3 \text { years }\end{array}$ & \\
\hline & $\begin{array}{l}\text { NEB. CONST. } \\
\text { art. V, § } 21(3)\end{array}$ & NEB. CONST. art. V, § 21 & $\begin{array}{l}\text { NEB. CONST. art. } \\
\mathrm{V}, \S 21(3)\end{array}$ & NEB. CONST. art. V, § 21 \\
\hline \multirow[t]{2}{*}{ Nevada } & $\begin{array}{l}\text { Generally two } \\
\text { years }\end{array}$ & Seniority & 6 years & Popular election \\
\hline & $\begin{array}{l}\text { NEV. CONST. } \\
\text { art. } 6, \S 3 \text {; NEV. } \\
\text { REV. STAT. } \\
\text { ANN. } \$ 2.030\end{array}$ & $\begin{array}{l}\text { NeV. CONST. art. } 6, \S 3 \text {; } \\
\text { NEV. REV. STAT. ANN. } \$ \\
2.030\end{array}$ & $\begin{array}{l}\text { NEV. CONST. art. } \\
6, \S 3 \text {; NEV. REV. } \\
\text { STAT. ANN. } \$ \\
2.030\end{array}$ & $\begin{array}{l}\text { Nev. Const. art. } 6 \text {, § 3; NeV. } \\
\text { ReV. StAT. ANN. } \$ 2.030\end{array}$ \\
\hline \multirow[t]{2}{*}{$\begin{array}{l}\text { New Hamp- } \\
\text { shire }\end{array}$} & $\begin{array}{l}\text { "Good behav- } \\
\text { ior;" manda- } \\
\text { tory retirement } \\
\text { at age } 70\end{array}$ & $\begin{array}{l}\text { Governor appoints; gover- } \\
\text { nor's council approves }\end{array}$ & $\begin{array}{l}\text { "Good behav- } \\
\text { ior;" mandatory } \\
\text { retirement at } \\
\text { age } 70\end{array}$ & $\begin{array}{l}\text { Governor appoints; gover- } \\
\text { nor's council approves }\end{array}$ \\
\hline & $\begin{array}{l}{ }^{a} \text { N.H. CONST. } \\
\text { pt. } 2 \text {, arts. } 73 \text {, } \\
78\end{array}$ & $\begin{array}{l}{ }^{a} \text { N.H. CONST. pt. 2, arts. } \\
46-47\end{array}$ & $\begin{array}{l}\text { N.H. CONST. pt. } \\
2 \text {, arts. } 73,78\end{array}$ & $\begin{array}{l}\text { N.H. CONST. pt. } 2 \text {, arts. } 46 \text {, } \\
47\end{array}$ \\
\hline \multirow[t]{3}{*}{ New Jersey } & $\begin{array}{l}\text { "Good behav- } \\
\text { ior;" manda- } \\
\text { tory retirement } \\
\text { at age } 70\end{array}$ & $\begin{array}{l}\text { Governor appoints; senate } \\
\text { consents }\end{array}$ & $\begin{array}{l}\text { "Good behav- } \\
\text { ior;" mandatory } \\
\text { retirement at } \\
\text { age } 70\end{array}$ & $\begin{array}{l}\text { Governor appoints; senate } \\
\text { consents }\end{array}$ \\
\hline & $\begin{array}{l}\text { Initial term }=7 \\
\text { years. }\end{array}$ & & $\begin{array}{l}\text { Initial term }=7 \\
\text { years. }\end{array}$ & \\
\hline & $\begin{array}{l}\text { "a.J. CONST. } \\
\text { art. VI, } \$ 6 \text {, I } 3\end{array}$ & N.J. CONST. art. VI, § 6, II 1 & $\begin{array}{l}\text { N.J. CONST. art. } \\
\text { VI, } \S 6 \text {, I } 3\end{array}$ & N.J. CONST. art. VI, § 6, II 1 \\
\hline \multirow[t]{2}{*}{ New Mexico } & 2 years & Court selection & 8 years & $\begin{array}{l}\text { Popular election; retention } \\
\text { election }\end{array}$ \\
\hline & $\begin{array}{l}\text { N. M. STAT. } \\
\text { ANN. § 34-2-1 }\end{array}$ & N. M. STAT. ANN. § 34-2-1 & $\begin{array}{l}\text { N.M. CONST. art. } \\
6, \S 33\end{array}$ & N.M. CONST. art. 6, § 33 \\
\hline \multirow[t]{2}{*}{ New York } & 14 years & $\begin{array}{l}\text { JNC nominates; governor } \\
\text { appoints; senate confirms }\end{array}$ & 14 years & $\begin{array}{l}\text { JNC nominates; governor } \\
\text { appoints; senate confirms }\end{array}$ \\
\hline & $\begin{array}{l}\text { N.Y. CoNST. art } \\
\text { VI, } § 2(a)\end{array}$ & N.Y. CONST. art VI, § 2 & $\begin{array}{l}\text { N.Y. CONST. art } \\
\text { VI, } \S 2(a)\end{array}$ & N.Y. CONST. art VI, § 2 \\
\hline
\end{tabular}




\begin{tabular}{|c|c|c|c|c|}
\hline \multirow[b]{2}{*}{ States } & \multicolumn{2}{|c|}{ Chief Justice } & \multicolumn{2}{|c|}{ Other Justices } \\
\hline & Tenure & Selection Method & Tenure & Selection Method \\
\hline \multirow{2}{*}{$\begin{array}{l}\text { North Caro- } \\
\text { lina }\end{array}$} & 8 years & Popular election & 8 years & Popular election \\
\hline & $\begin{array}{l}\text { N.C. GEN. } \\
\text { STAT. ANN. § } \\
\text { 7A-10(a) }\end{array}$ & $\begin{array}{l}\text { N.C. GEN. STAT. ANN. \$ 7A- } \\
10 \text { (a) }\end{array}$ & $\begin{array}{l}\text { N.C. GEN. STAT. } \\
\text { ANN. } \$ 7 A-10(a)\end{array}$ & $\begin{array}{l}\text { N.C. GEN. STAT. ANN. \$ 7A- } \\
10 \text { (a) }\end{array}$ \\
\hline \multirow[t]{2}{*}{ North Dakota } & $\begin{array}{l}5 \text { years or until } \\
\text { term on court } \\
\text { expires, which- } \\
\text { ever occurs } \\
\text { first }\end{array}$ & $\begin{array}{l}\text { Selection by judges of } \\
\text { supreme and district } \\
\text { courts }\end{array}$ & 10 years & Popular election \\
\hline & $\begin{array}{l}\text { N.D. CENT. } \\
\text { CODE } § 27-02- \\
01\end{array}$ & $\begin{array}{l}\text { N.D. CENT. CODE } § 27-02- \\
01\end{array}$ & $\begin{array}{l}\text { N.D. CONST. art. } \\
6, \S 7\end{array}$ & N.D. CONST. art. $6, \S 7$ \\
\hline \multirow[t]{2}{*}{ Ohio } & 6 years & Popular election & 6 years & Popular election \\
\hline & $\begin{array}{l}\text { OHIO CONST. } \\
\text { art. IV, } \S \\
6(\mathrm{~A})(1)\end{array}$ & $\begin{array}{l}\text { OHIO CONST. art. IV, } \S \\
6(\mathrm{~A})(1)\end{array}$ & $\begin{array}{l}\text { OHIO CONST. } \\
\text { art. IV }, \S \\
6(\mathrm{~A})(1)\end{array}$ & $\begin{array}{l}\text { OHIO CONST. art. IV, } \S \\
6(\mathrm{~A})(1)\end{array}$ \\
\hline \multirow[t]{3}{*}{ Oklahoma } & 2 years & Court selection & 6 years & $\begin{array}{l}\text { JNC nominates; governor } \\
\text { appoints; retention election }\end{array}$ \\
\hline & & & $\begin{array}{l}\text { Initial term = at } \\
\text { least } 1 \text { year }\end{array}$ & \\
\hline & $\begin{array}{l}{ }^{c, d} \text { OKLA. STAT. } \\
\text { ANn. tit. 5, ch. } \\
\text { 1, app. 7, App. } \\
\text { Div. R. 1 }\end{array}$ & $\begin{array}{l}\text { OKLA. CONST. art. VII, } \$ 2 \text {; } \\
\text { OKLA. STAT. ANn. tit. } 5 \text {, ch. } \\
\text { 1, app. 7, App. Div. R. } 1\end{array}$ & $\begin{array}{l}\text { OKLA. CONST. } \\
\text { art. VII, } § 2 \text {; } \\
\text { OKLA. CONST. } \\
\text { art VII-B, } § 5\end{array}$ & OKLA. CONST. art. VII-B \\
\hline \multirow[t]{2}{*}{ Oregon } & 6 years & Court selection & 6 years & Popular election \\
\hline & $\begin{array}{l}\text { OR. REV. STAT. } \\
\text { ANN. } \$ 2.045\end{array}$ & $\begin{array}{l}\text { OR. REV. STAT. ANN. } \\
2.045\end{array}$ & $\begin{array}{l}\text { OR. CONST. art. } \\
\text { VII, } \S 1\end{array}$ & OR. CONST. art. VII, $\S 1$ \\
\hline \multirow[t]{2}{*}{ Pennsylvania } & $\begin{array}{l}\text { Duration of } \\
\text { service }\end{array}$ & Seniority & 10 years & $\begin{array}{l}\text { Governor appoints; senate } \\
\text { consents; retention election }\end{array}$ \\
\hline & $\begin{array}{l}\text { PA. CONST. art. } \\
\mathrm{V} \S 10(\mathrm{~d})\end{array}$ & PA. CONST. art. V $\S 10(d)$ & $\begin{array}{l}\text { PA. CONST. art. V } \\
\S \S 13(\mathrm{a}), 15(\mathrm{a})\end{array}$ & $\begin{array}{l}\text { PA. CONST. art. V } \S \S 13(\mathrm{a}) \\
15 \text { (b) }\end{array}$ \\
\hline \multirow[t]{2}{*}{ Rhode Island } & $\begin{array}{l}\text { "Good behav- } \\
\text { ior" }\end{array}$ & $\begin{array}{l}\text { JNC nominates; governor } \\
\text { appoints; consent of Sen- } \\
\text { ate and House of Repre- } \\
\text { sentatives }\end{array}$ & "Good behavior" & $\begin{array}{l}\text { JNC nominates; governor } \\
\text { appoints; consent of Senate } \\
\text { and House of Representa- } \\
\text { tives }\end{array}$ \\
\hline & $\begin{array}{l}{ }^{a} \text { R.I. CONST. } \\
\text { art. X, } \S 5\end{array}$ & ${ }^{a}$ R.I. CONST. art. X, $\S 4$ & $\begin{array}{l}\text { R.I. CONST. art. } \\
\mathrm{X}, \S 5\end{array}$ & R.I. CONST. art. X, $\S 4$ \\
\hline \multirow{2}{*}{$\begin{array}{l}\text { South Caro- } \\
\text { lina }\end{array}$} & 10 years & Legislature selects & 10 years & Legislature selects \\
\hline & $\begin{array}{l}\text { S.C. CONST. } \\
\text { art. V, § 3; } \\
\text { S.C. CODE ANN. } \\
\text { § 14-3-10 }\end{array}$ & $\begin{array}{l}\text { S.C. ConsT. art. V, § 3; S.C. } \\
\text { Code ANN. } \$ 14-3-10\end{array}$ & $\begin{array}{l}\text { S.C. CONST. art. } \\
\text { V, \$ } 3 ; \\
\text { S.C. CODE ANN. } \\
\S 14-3-10\end{array}$ & $\begin{array}{l}\text { S.C. CONST. art. V, § 3; } \\
\text { S.C. CODE ANN. § 14-3-10 }\end{array}$ \\
\hline \multirow[t]{2}{*}{ South Dakota } & 4 years & Court selection & $\begin{array}{l}8 \text { years } \\
\text { Initial term = at } \\
\text { least } 3 \text { years }\end{array}$ & $\begin{array}{l}\text { JNC nominates; governor } \\
\text { appoints; retention election }\end{array}$ \\
\hline & $\begin{array}{l}\text { S.D. CODIFIED } \\
\text { LAWs } § 16-1-2.1\end{array}$ & $\begin{array}{l}\text { S.D. CONST. art. V, } \S 8 \text {; } \\
\text { S.D. CODIFIED LAWS } § 16-1 \text { - } \\
\text { 2.1 }\end{array}$ & $\begin{array}{l}\text { S.D. CONST. art. } \\
\text { V, } \S 7\end{array}$ & S.D. ConsT. art. V, $\S 7$ \\
\hline
\end{tabular}




\begin{tabular}{|c|c|c|c|c|}
\hline \multirow[b]{2}{*}{ States } & \multicolumn{2}{|c|}{ Chief Justice } & \multicolumn{2}{|c|}{ Other Justices } \\
\hline & Tenure & Selection Method & Tenure & Selection Method \\
\hline \multirow[t]{2}{*}{ Tennessee } & 4 years & Court selection & 8 years & $\begin{array}{l}\text { JNC nominates; governor } \\
\text { appoints; retention election }\end{array}$ \\
\hline & $\begin{array}{l}\text { 'TENN. Sup. CT. } \\
\text { R. } 32\end{array}$ & $\begin{array}{l}\text { TENN. CONST. art. VI, § 2; } \\
\text { TENN. CoDE ANN. § 16-3- } \\
102\end{array}$ & $\begin{array}{l}\text { TENN. CONST. } \\
\text { art. VI, } \$ 3\end{array}$ & $\begin{array}{l}\text { TenN. Const. art. VI, } \$ 3 \text {; } \\
\text { TENN. CODE ANN. } \$ \$ 17-4- \\
112,17-4-115\end{array}$ \\
\hline \multirow[t]{2}{*}{ Texas } & 6 years & Popular election & 6 years & Popular election \\
\hline & $\begin{array}{l}\text { TEX. CONST. } \\
\text { art. V, } \S 2 \\
\end{array}$ & TEX. Const. art. V, $\S 2$ & $\begin{array}{l}\text { TEX. Const. art. } \\
\mathrm{V}, \S 2\end{array}$ & TEx. ConsT. art. V, $§ 2$ \\
\hline \multirow[t]{3}{*}{ Utah } & 4 years & Court selection & 10 years & $\begin{array}{l}\text { JNC nominates; governor } \\
\text { appoints; senate confirms }\end{array}$ \\
\hline & & & $\begin{array}{l}\text { Initial term = at } \\
\text { least } 3 \text { years }\end{array}$ & \\
\hline & $\begin{array}{l}\text { UTAH CODE } \\
\text { ANN. } § 78-2-1\end{array}$ & UTAH CODE ANN. § 78-2-1 & $\begin{array}{l}\text { UTAH CODE } \\
\text { ANN. } § 78-2-1\end{array}$ & UTAH CONST. art. VIII, $\S 8$ \\
\hline \multirow[t]{2}{*}{ Vermont } & 6 years & $\begin{array}{l}\text { JNC nominates; governor } \\
\text { appoints; senate consents }\end{array}$ & 6 years & $\begin{array}{l}\text { JNC nominates; governor } \\
\text { appoints; senate consents }\end{array}$ \\
\hline & $\begin{array}{l}\text { "VT. CONST. } \\
\text { Ch. II, § } 34 \\
\end{array}$ & Vt. Const. Ch. II, § 32 & $\begin{array}{l}\text { VT. CONST. Ch. } \\
\text { II, } \S 34\end{array}$ & Vt. Const. Ch. II, § 32 \\
\hline \multirow[t]{2}{*}{ Virginia } & 4 years & Court selection & 12 years & Legislature selects \\
\hline & $\begin{array}{l}\text { VA. CODE ANN. } \\
\S 17.1-300\end{array}$ & VA. CODE ANN. $\$ 17.1-300$ & $\begin{array}{l}\text { VA. CONST. art. } \\
\text { VI, } \S 7\end{array}$ & VA. CONST. art. VI, $\S 7$ \\
\hline \multirow[t]{2}{*}{ Washington } & 4 years & Court selection & 6 years & Popular election \\
\hline & $\begin{array}{l}\text { WASH. CONST. } \\
\text { art. IV, } \$ 3 \\
\end{array}$ & WASH. CONST. art. IV, $§ 3$ & $\begin{array}{l}\text { WASH. CONST. } \\
\text { art. IV, } \S 3\end{array}$ & WASH. CONST. art. IV, $§ 3$ \\
\hline \multirow[t]{2}{*}{ West Virginia } & 1 year & Rotation by seniority & 12 years & Popular election \\
\hline & $\begin{array}{l}\text { 'W. VA. CODE } \\
\text { ANN. § 51-1-2; } \\
\text { Order Re: } \\
\text { Designation of } \\
\text { Chief Justice }\end{array}$ & ${ }^{d}$ W. VA. CODE ANN. § 51-1-2 & $\begin{array}{l}\text { W. VA. CONST. } \\
\text { art. VIII, } § 2\end{array}$ & W. VA. CONST. art. VIII, $§ 2$ \\
\hline \multirow[t]{2}{*}{ Wisconsin } & $\begin{array}{l}\text { Duration of } \\
\text { service }\end{array}$ & Seniority & 10 years & Popular election \\
\hline & $\begin{array}{l}\text { WIs. CONST. } \\
\text { art. VII, } § 4\end{array}$ & WIS. CONST. art. VII, $\S 4$ & $\begin{array}{l}\text { WIS. CONST. art. } \\
\text { VII, } \S 4\end{array}$ & WIS. CONST. art. VII, $\S 4$ \\
\hline \multirow[t]{3}{*}{ Wyoming } & 4 years & Court selection & 8 years & $\begin{array}{l}\text { JNC nominates; governor } \\
\text { appoints; retention election }\end{array}$ \\
\hline & & & $\begin{array}{l}\text { Initial term = at } \\
\text { least } 1 \text { year }\end{array}$ & \\
\hline & $\begin{array}{l}\text { 'WYO. STAT. } \\
\text { ANN. § 5-2-102 }\end{array}$ & $\begin{array}{l}\text { WYo. ConsT. art. V, § 4; } \\
\text { WYo. STAT. ANN. \$ 5-2-102 }\end{array}$ & $\begin{array}{l}\text { WYO. CONST. art. } \\
\mathrm{V}, \S 4\end{array}$ & WYO. CONST. art. V, § 4 \\
\hline
\end{tabular}

All rights reserved, Chinelo Dike, Lane Dilg, \& Judith Resnik @ April 2006.

\section{Methodological Note}

The term "chief justice" refers to the presiding justice or judge of a state's highest court. 
"Court selection" means that a chief justice is selected by the other justices of that court.

The terms "popular election" or "election" refer to selection by a state's electorate; such elections are sometimes required to be "nonpartisan."

The abbreviation "JNC" stands for a Judicial Nominating Commission, which is the phrase often used to describe a group chartered to propose justices. Other appellations for such groups include a Commission on Appellate Court Appointments, Judicial Selection Commission, or Judicial Qualifications Commission.

Most sources are cited directly in the body of the chart. Additional information comes from the monograph, State Court Organization 1998 (2000), by David B. Rottman, Carol R. Flango, Melissa T. Cantrell, Randall Hansen \& Neil LaFountain of the Bureau of Justice Statistics, U.S. Department of Justice, as well as from court rules, court orders, and telephone interviews. In a few instances (California, Maine, Maryland, Massachusetts, Minnesota, New Hampshire, New Jersey, Rhode Island, and Vermont), denoted (a), the source cited does not expressly address the tenure of the chief justiceship. The information reported is the tenure provided for members of that state's high court. For California and Minnesota, denoted (b), we relied on such general provisions, supplemented by information from those states' election laws. Further, in discussion of Florida, Georgia, Michigan, Missouri, Oklahoma, Tennessee, and West Virginia, marked (c), the reported information comes from court orders or rules rather than statutes or constitutional provisions. And, for Oklahoma, West Virginia, and Wyoming, denoted by (d), our sources were telephone interviews, as supplemented by the monograph, State Court Organization 1998, cited above. 